\author{
UNIVERSIDADE DE BRASÍLIA \\ FACULDADE DE CEILÂNDIA \\ PÓS-GRADUAÇÃO EM CIÊNCIAS E TECNOLOGIAS EM SAÚDE
}

MARCUS AURELIO DA COSTA TAVARES SABINO

INVESTIGAÇÃO DO METABOLISMO REDOX EM UM

MODELO ANIMAL TOLERANTE A SITUAÇÕES POTENCIALMENTE DANOSAS À SAÚDE

ORIENTADOR: DR. ALEXIS F. WELKER CO-ORIENTADOR: DR. MARCELO HERMES-LIMA

BRASÍLIA

2016 
MARCUS AURELIO DA COSTA TAVARES SABINO

\section{INVESTIGAÇÃO DO METABOLISMO REDOX EM UM \\ MODELO ANIMAL TOLERANTE A SITUAÇÕES \\ POTENCIALMENTE DANOSAS À SAÚDE}

Dissertação apresentada ao Programa de Pós-Graduação em Ciências e Tecnologias em Saúde da Universidade de Brasília para a obtenção do título de Mestre.

Orientador: Dr. Alexis Fonseca Welker.

Co-Orientador: Dr. Marcelo Hermes-Lima.

\section{BRASÍLIA}

2016 
Ficha catalográfica elaborada pela Biblioteca Central da Universidade de Brasília.

Sabino, Marcus 


\title{
INVESTIGAÇÃO DO METABOLISMO REDOX EM UM \\ MODELO ANIMAL TOLERANTE A SITUAÇÕES \\ POTENCIALMENTE DANOSAS À SAÚDE
}

\section{MARCUS AURELIO DA COSTA TAVARES SABINO}

\begin{abstract}
Dissertação defendida no Programa de Pós-graduação “Stricto Sensu” em Ciências e Tecnologias em Saúde da Universidade de Brasília, como parte das exigências para a obtenção do título de Mestre. Número de páginas: 74 .

Banca examinadora constituída pelos seguintes membros:
\end{abstract}

Prof. Dr. Alexis Fonseca Welker

Universidade de Brasília

Programa de Pós-Graduação em Ciências e Tecnologias em Saúde

Profa. Dr. Vicente de Paulo Martins

Universidade de Brasília

Programa de Pós-Graduação em Ciências e Tecnologias em Saúde

Prof. Dr. Eduardo Antônio Ferreira

Universidade de Brasília

Profa. Dra. Tatiana Ramos Lavich

Universidade de Brasília 


\section{AGRADECIMENTOS}

Agradeço imensamente a meu pai que sempre apoiou meus estudos, minha dedicação e vontade de querer aprender e realizar meus sonhos, infelizmente ele não teve esta oportunidade, não estaria aqui senão fosse por seu imenso e arduoso trabalho, pela sua paciência e preocupação após permanecer dias fora de casa fazendo meu trabalho.

Agradeço aos meus parentes pelo grande apreço dado a minha vida, em especial minhas duas mães.

Agradeço à Cida Aguiar, minha namorada, pela imensa paciência e preocupação das horas em que eu chegava a minha casa tarde.

Agradeço aos inúmeros colegas e amigos que fiz e passaram no laboratório de radicais livres, no qual tive a oportunidade de conhecer.

Agradeço ao biólogo Roberto Andrade Junior pelo treinamento no grupo dos ANIMAIS.

Agradeço à farmacêutica e Mestra Juliana Bicálio pelo treinamento inicial que tive no laboratório, além do bom convívio.

Agradeço à Dra. Luana Dalvi pelo excelente convívio no laboratório por anos.

Agradeço ao ex IC do laboratório, Igor Santos, por ajudar em uma das coletas e por ajudar e acompanhar de perto os experimentos.

Agradeço a Hylane e Lara pelo bom convívio no laboratório.

Agradeço ao aluno de doutorado na época e hoje orientador e professor Dr. Alexis Welker pelos incentivos, aprendizagens metodologicas e oportunidades de fazer iniciação científica e mestrado na UnB.

Agradeço ao técnico do laboratório Francisco Orivan "Chiquinho" pelas muitas ajudas incontáveis no laboratório, além das prosas do corredor, saudáveis ao bom convívio social.

Agradeço ao grande amigo Daniel Carneiro Moreira, que virou um grande gênio da bancada e biologia experimental, por suas ideias, críticas, sugestões, e ceticismo experimental, pela ajuda e ideias na coleta do dia I, pela ajuda nas parafernalhas eletrônicas que horas funcionam, horas não funcionam, e com paciência e astúcia conseguia sanar na medida do possível os experimentos devido a sua larga experiência em informática.

Agradeço a professora Dra. Carolina Arruda Freire e o seu aluno de mestrado Leonardo Rios pela colaboração, ajuda na coleta, identificação da espécie estudada, e hospedagem/tour em Curitiba.

Agradeço ao professor Dr. Marcelo Hermes-Lima pelo convite de ter entrado precocemente no seu laboratório, pelas inúmeras dicas, discussões, pelo incentivo de fazer ciência de alto nível "fronteira", pela oportunidade de encabeçar este projeto, de tomar a frente dele, pela oportunidade de contribuir na confecção de artigo científico, por representar o laboratório internacionalmente com os estudos desta dissertação e conhecer pessoas diferentes no mundo científico.

Agradeço a CAPES pelo incentivo de fazer este trabalho com bolsa, e aos funcionários da secretaria da pós-graduação da FCE pelo bom atendimento que recebi.

"Se eu vi mais longe, foi por estar ao ombro de gigantes". Isaac Newton 


\section{ÍNDICE}

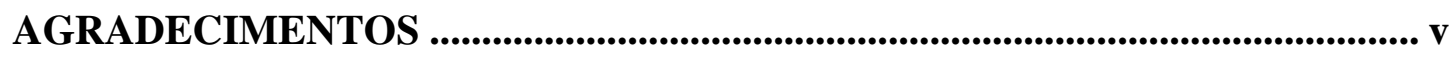

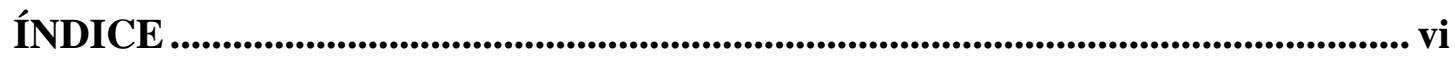

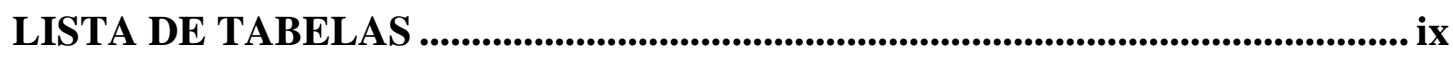

LISTA DE ABREVIAÇÕES.................................................................................

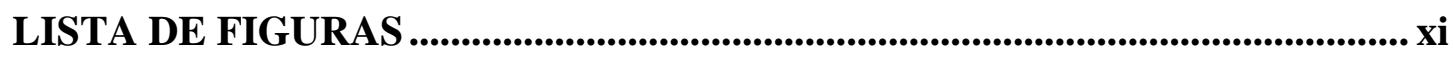

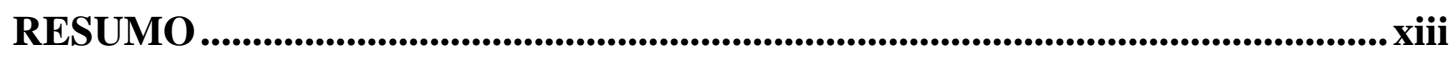

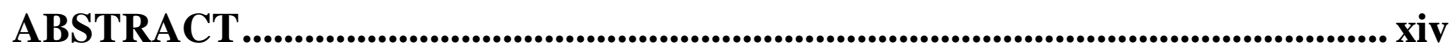

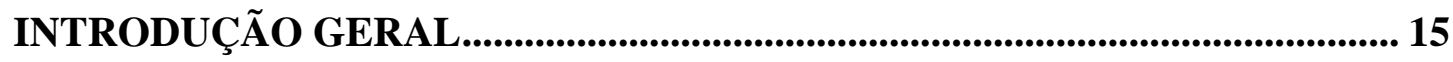

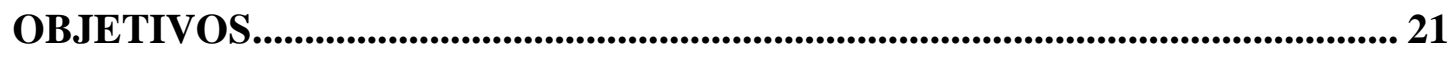

CAPÍTULO 1 - MANUSCRITO 1: METABOLISMO DA GLUTATIONA NO MEXILHÃO MYTILASTER SOLISIANUS (MYTILIDAE) EM CICLOS NATURAIS DE MARÉS................................................................................... 22

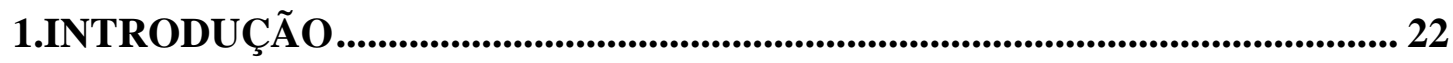

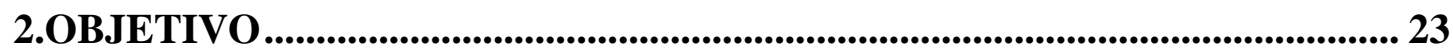

3.MATERIAL E MÉTODOS ................................................................................... 23

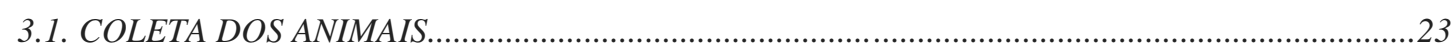

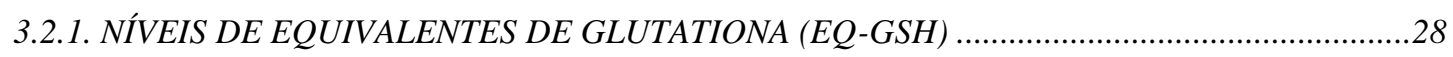

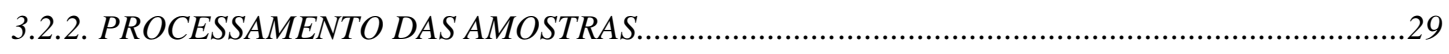

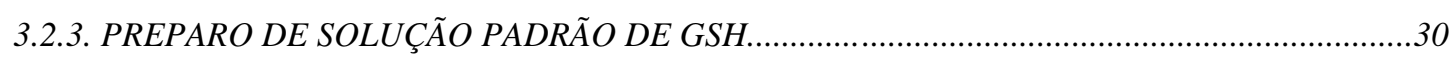

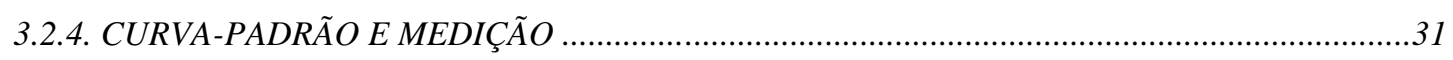

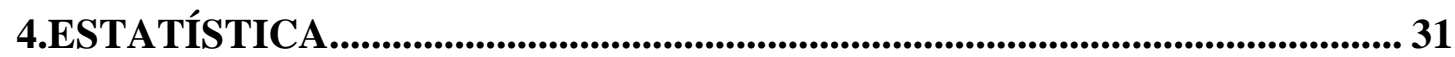

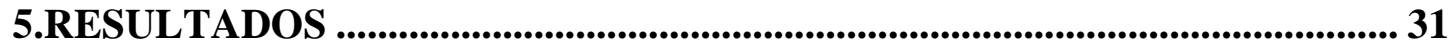

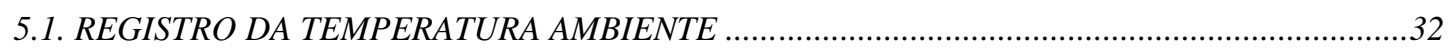

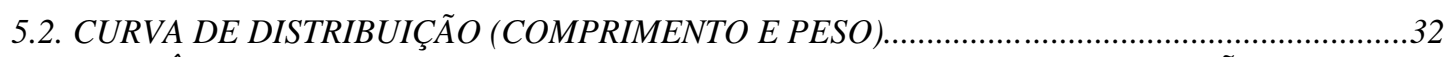

5.3. PARÂMETROS DE GLUTATIONA (EQ-GSH, GSH, GSSG E RAZÃO GSSG/EQGSH)...

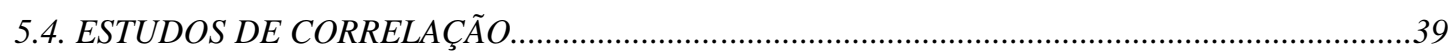

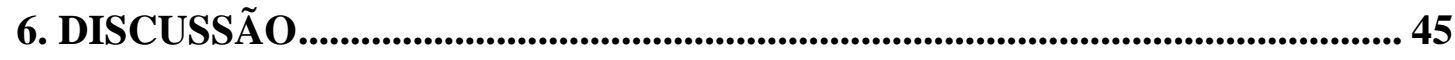

7. CONCLUSÕES E PERSPECTIVAS .............................................................. 52 
8. REFERÊNCIAS BIBLIOGRÁFICAS ............................................................. 53

CAPÍTULO 2 - MANUSCRITO 2: HOW WIDESPREAD IS PREPARATION FOR OXIDATIVE STRESS IN THE ANIMAL KINGDOM? ........................... 61

3. DISCUSSÃO GERAL E CONCLUSÕES ........................................................ 62

ANEXO A - Pedra na qual os animais foram coletados nas três coletas, foto específica da coleta I.................................................................................................... 73

ANEXO B - Registro por fotos ao longo do tempo durante a baixa e alta da maré na coleta III ................................................................................................................................... 74 
ANEXO A - Pedra na qual os animais foram coletados nas três coletas, foto específica da coleta I..................................................................................................................... 73

ANEXO B - Registro por fotos ao longo do tempo durante a baixa e alta da maré na coleta III. Ao centro, registro da temperatura do ar e água em função do tempo. No painel superior da figura, condição de coleta dos animais, incluindo tempo no qual os mesmos estavam reimersos (círculos em preto) ou expostos ao ar (os círculos em branco). Autor das fotos e figura: Marcus Sabino. 74 


\section{LISTA DE TABELAS}

Tabela1. Comparação dos parâmetros de Eq-GSH, GSH, GSSG (nmol/g tecido) e razão GSSG/Eq-GSH em invertebrados. 


\section{LISTA DE ABREVIAÇÕES}

BAX BCL2-associated X protein

BCL2 B cell linfoma 2

DTNB 5,5'-ditiobis-2-ácido nitrobenzóico

Eq-GSH Equivalents de glutationa

EROs Espécies reativas de oxigênio

FOX Forkhead box

G6PDH Glicose-6-fosfato desidrogenase

GSH Glutationa

GSSG Glutationa dissulfeto

Se-GPx Glutationa peroxidase dependende de selênio

GPx Glutationa peroxidase

GR Glutationa redutase

GST Glutationa transferase

HSP Proteínas de choque térmico

$\mathrm{H}_{2} \mathrm{O}_{2} \quad$ Peróxido de hidrogênio

HIF Fator induzido por hipóxia

LDH Lactato desidrogenase

Nrf2 Nuclear fator eritroide 2

Prx Peroxiredoxina

POS Preparo para o estresse oxidativo

$\mathrm{O}_{2} \quad$ Oxigênio

$\cdot \mathrm{OH} \quad$ Radical hidroxil

$\mathrm{O}_{2}^{-} \quad$ Radical ânion superóxido

OMS Organização Mundial de Saúde

SOD Superóxido dismutase

SOD1 Superóxido dismutase dependente de cobre e zinco

TCA Ácido tricloroacético

TNB 5-tio-2-ácido nitrobenzóico

$\mathrm{XO} \quad$ Xantina oxidase

$\mathrm{XDH} \quad$ Xantina desidrogenase

2-VP 2-vinilpiridina

4-HNE 4-hidroxinonenal 


\section{LISTA DE FIGURAS}

Figura 1. Tábua das marés (u.a. unidade arbitraria) para as três coletas mostrando momentos em que a maré alta se encontra no seu pico em seus respectivos dias, e os animais se encontram imersos, e momentos de maré baixa e os animais emersos, nos dias 1 e 2 de novembro de 2014 (à esquerda e ao centro da figura), e para o dia 09 de maio (à direita). Fonte: Tábua das Marés, Marinha do Brasil <http://www.mar.mil.br/dhn/chm/box-previsao-mare/tabuas/> .25

Figura 2. A. Coleta de mexilhões durante a exposição aérea. B. Seta apontando para o bisso.

Figura 3. Grupos experimentais das três coletas. Os grupos destacados foram escolhidos para a realização das análises de GSH nos mexilhões

Figura 4. Reação entre DTNB e 2 moléculas de GSH, produzindo TNB (detectado em $412 \mathrm{~nm}$ ) e GS-TNB. Glutationa redutase (GR) reduz GS-TNB na presença de NADPH, e GSH é produzida novamente e retorna a participar da reação com DTNB, enquanto que GSSG presente na amostra também é biotransformada produzindo duas moléculas de GSH. Figura modificada de Rahman et al., (2006), e Caito e Aschner (2015)

Figura 5. Registro da temperatura da água e ar ao longo das três coletas. .33

Figura 6. Dados de distribuição $(\%)$ do comprimento $(\mathrm{cm})$ e peso dos mexilhões (mg). N=146 animais. A. Comprimento dos animais (cm). B. Peso dos animais (mg)

Figura 7. Regressão linear entre comprimento $(\mathrm{cm})$ e peso $(\mathrm{mg})$ nos mexilhões. $\mathrm{N}=146$ animais

Figura 8. Níveis totais de glutationa (Eq-GSH) nos mexilhões medidos nas três coletas durante a reimersão e exposição aérea. Dados representados com média e erro padrão da média. $\mathrm{N}=(6-9)$ animais por grupo experimental. Dados dos níveis Eq-GSH da coleta I à esquerda, coleta II no centro, coleta III à direita. * Diferença significativa com $\mathrm{P}=0,050$.

Figura 9. Níveis de glutationa (GSH) nos mexilhões medidos nas três coletas durante a reimersão e exposição aérea. Dados representados com média e erro padrão da média. N=(6-9) animais por grupo experimental. Dados dos níveis de GSH da coleta I à esquerda, coleta II no centro, e coleta III à direita. 
Figura 10. Níveis de GSSG nos mexilhões medidos nas três coletas durante a reimersão e exposição aérea. Dados representados com média e erro padrão da média. $\mathrm{N}=(6-9)$ animais por grupo experimental. Dados dos níveis de GSSG da coleta I à esquerda, coleta II no centro, coleta III à direita. .36

Figura 11. Níveis de GSSG/Eq-GSH nos mexilhões medidos nas três coletas durante a reimersão e exposição aérea. Dados representados com média e erro padrão da média. $\mathrm{N}=(6-9)$ animais por grupo experimental. Dados da razão GSSG/Eq-GSH da coleta I à esquerda, coleta II no centro, coleta III à direita.

Figura 12. Correlação entre os níveis de GSH e Eq-GSH em todos os mexilhões analisados. $\mathrm{N}=146$ animais.

Figura 13. Correlação entre os níveis de GSSG e Eq-GSH em todos os mexilhões analisados. $\mathrm{N}=146$ animais. .41

Figura 14. Correlação entre os níveis de GSH e a razão GSSG/Eq-GSH em todos os mexilhões analisados. $\mathrm{N}=146$ animais.

Figura 15. Correlação entre os níveis de GSSG e a razão GSSG/Eq-GSH em todos os mexilhões analisados. $\mathrm{N}=146$ animais.

Figura 16. Correlação entre os níveis de Eq-GSH e comprimento em todos os mexilhões analisados. $\mathrm{N}=146$ animais .042

Figura 17. Correlação entre os níveis de GSH e comprimento em todos os mexilhões analisados. $\mathrm{N}=146$ animais.

Figura 18. Correlação entre os níveis de GSSG e comprimento em todos os mexilhões analisados. $\mathrm{N}=146$ animais.

Figura 19. Correlação entre a razão GSSG/Eq-GSH e comprimento em todos os mexilhões analisados. $\mathrm{N}=146$ animais.

Figura 20. Correlação entre os níveis de Eq-GSH e peso em todos os mexilhões analisados. $\mathrm{N}=146$ animais

Figura 21. Correlação entre os níveis de GSH e peso em todos os mexilhões analisados. $\mathrm{N}=146$ animais

Figura 22. Correlação entre os níveis de GSSG e peso em todos os mexilhões analisados. $\mathrm{N}=146$ animais

Figura 23. Correlação entre a razão GSSG/Eq-GSH e peso em todos os mexilhões analisados. $\mathrm{N}=146$ animais 


\section{RESUMO}

Nos animais sensíveis à privação de $\mathrm{O}_{2}$, é observada a injúria tecidual durante a hipóxia e o reoxigenação, tendo como causa principal o estresse oxidativo gerado por radicais livres derivados do oxigênio. Uma das estratégias encontradas por uma ampla variedade de animais à escassez de oxigênio é responder a este insulto com aumento das defesas antioxidantes, e assim evitar o dano oxidativo causado pelos radicais livres, fenômeno nomeado de preparo para o estresse oxidativo (POS). Nossa pergunta é saber se o fenômeno bioquímico do POS acontece na natureza, em especial, no ambiente entre marés, no qual mudanças cíclicas de retirada e oferta de oxigênio acontecem durante a baixa e alta das marés. Nestas condições de baixa e alta da maré em uma praia de Penha (Santa Catarina, Brasil), foi estudado o metabolismo redox envolvendo glutationa (GSH), em análise de corpo inteiro nos mexilhões da espécie Mytilaster solisianus, em três diferentes coletas (chamadas de I, II e III). Os animais mostraram suportar o esperado desequilíbrio redox durante as situações de exposição aérea (de até quatro horas na coleta I e II, e até 9 horas na coleta III) e reimersão no campo, pois os parâmetros antioxidantes endógenos relacionados ao metabolismo de GSH estiveram inalterados durante o ciclo das marés (i.e. Eq-GSH, GSH, GSSG e GSSG/Eq-GSH). Todavia na coleta III, houve uma queda dos níveis totais de Eq-GSH após duas horas de exposição aérea em relação ao grupo de animais pré-imersos. Na coleta III houve uma forte variação da temperatura do ar ao longo da exposição aérea (de 19 para $28^{\circ} \mathrm{C}$ ), apesar disso, o indicador de desequilibrio redox não mudou (razão GSSG/Eq-GSH), mostrando que estes animais têm alto grau de adaptabilidade neste ambiente, no qual os fatores abióticos estão em constante mudança.

Palavras chave: preparo para o estresse oxidativo (POS), hipóxia, exposição aérea, glutationa (GSH), radicais livres, Mylaster solisianus. 


\begin{abstract}
In animals sensible to oxygen privation is seen injury in their tissues during hypoxia and reoxygenation, and the main cause is the oxidative stress generated by oxygenderived free radicals. One of the strategies found by a widespread variety of animals to survive oxygen lack is respond with increase of antioxidant defenses, and thus avoiding the oxidative damage caused by free radicals, a phenomenon named preparation for oxidative stress (POS). Our question address if biochemical phenomenon of POS happens in nature, in special, in the intertidal environment, where changes cyclical of lack and supply oxygen happens during low and high tide. In these conditions of low and high tide in beach of Penha (Santa Catarina, Brazil), was studied redox metabolism of glutathione (GSH), in body whole analysis in the mussel specie Mytilaster solisianus in three differents expeditions (named of I, II e III). The animals shown endure to the expected redox imbalance during aerial exposure (until four hours in expedition I e II, and until 9 hours in expedition III) and reimmersion in field, because the endogenous antioxidant parameters related to the metabolism of the glutathione remained unchanged during tidal cycle (i.e GSH-eq, GSH, GSSG and GSSG/GSH-eq ratio). However in expedition III, there was a drop in glutathione pool (GSH-eq) after two hours of aerial exposure when compared to group of animals pre-emersion. In expedition III there was a strength variation in air temperature $\left(19\right.$ to $28^{\circ} \mathrm{C}$ ) during aerial exposure, despite this, the index of redox imbalance remained unchanged (GSSG/GSH-eq) in expedition III, showing that mussels have high level of adaptability in this environment, in which abiotic factors are in continuous changes.
\end{abstract}

Keywords: preparation for oxidative stress (POS), hypoxia, aerial exposure, glutathione (GSH), free radicals, Mytilaster solisianus. 


\section{INTRODUÇÃO GERAL}

No decorrer dos anos 80 e 90 do século XX iniciaram-se os estudos moleculares que associavam a geração em excesso de radicais livres derivados do oxigênio molecular $\left(\mathrm{O}_{2}\right)$ como o responsável pela injúria da isquemia (privação sanguínea) e reperfusão (reintrodução sanguínea) em tecidos de camundongos. A incubação tecidual com antioxidantes enzimáticos como superóxido dismutase (SOD) e catalase aumentava a viabilidade celular destes (Zewier et al., 1987; Zewier et al., 1988). Ao submeter camundongos transgênicos que super-expressam SOD1 (isoforma dependente de cobre e zinco) à isquemia e reperfusão no miocárdio, a concentração de radicais livres é mantida no nível do controle, gerando menos necrose tecidual quando comparado com o tecido que não super-expressa SOD1 (Wang et al., 1998). Ainda neste contexto, tinham-se evidências experimentais de que os radicais livres aumentavam de concentração durante a isquemia, por outro lado a reperfusão hipóxica gerava menos radicais de oxigênio do que a reperfusão normóxica, ilustrando a relação (paradoxal) entre a variação da disponibilidade do $\mathrm{O}_{2}$ (molécula fundamental para a vida aeróbica) e injúria (Zewier et al., 1987; Bolli et al., 1989).

Na época, acreditava-se que determinados sistemas enzimáticos, como xantina oxidase $(\mathrm{XO})$ (formada através da proteólise durante os processos de extração e purificação ou a partir da oxidação de resíduos sulfidrilas de cisteína de xantina desidrogenase $(\mathrm{XDH})$ ) era considerada como fonte de radicais livres de oxigênio durante o estresse oxidativo pós-isquêmico, produzindo radical anion superóxido $\left(\mathrm{O}_{2}{ }^{-}\right.$ ) e o mais reativo radical livre hidroxil $\left({ }^{\circ} \mathrm{OH}\right)$ (este tem sua produção favorecida em condições isquêmicas), ambas são espécies reativas de oxigênio (EROs) (MacCord, 1985; Kuppusamy e Zweier, 1989). Mas recentemente, parece que a forma enzimática responsável majoritariamente pela produção de EROs se dá não por XO, mas sim por XDH (90\% da enzima é encontrada nesta forma) (Lee et al., 2014), pois pouca alteração da atividade de XO ocorria na fase isquêmica ou na reperfusão, mas sim aumento de seus substratos na fase isquêmica, xantina e hipoxantina, formados a partir da degradação de ATP (este é depletado durante a isquemia), sendo os substratos que disparam o excesso da geração de EROs na reperfusão mediado por 
XDH (Xia e Zweier, 1995; Lee et al., 2014). Em paralelo a estes estudos, em camundongos, mostrou-se que os metabólitos xantina, hipoxantina e succinato são os que mais se acumulam quando diferentes órgãos são submetidos à isquemia (i.e. cérebro, coração, fígado e rim), através de estudo por metabolômica por meio de espectrometria de massas (Chouchani et al., 2014).

O succinato foi postulado como o responsável pelos níveis aumentados de EROs gerados pela mitocôndria na fase isquêmica, com maiores níveis gerados durante a reperfusão, e alto grau de área infartada, mas o bloqueio farmacológico da rota bioquímica de produção de succinato (i.e. succinato desidrogenase) previamente à isquemia, diminuía a produção de EROs na fase isquêmica e também na reperfusão, e os tecidos apresentavam menor área infartada, porém pouca atenção foi dada aos metabólitos xantina e hipoxantina (Chouchani et al., 2014). Mais evidências mostram que a inibição de succinato desidrogenase (complexo II da mitocôndria) por malonato reduz o tamanho da área infartada do miocárdio dos camundongos, com menor produção de EROs, menor liberação de lactato desidrogenase tecidual (LDH), um indicador de morte celular, pois com a ocorrência de dano celular, tem-se o extravasamento do seu conteúdo, isto promove a liberação de moléculas intracelulares para o sangue, como LDH, e como esta pode ser detectada pelos seus níveis de atividade, quanto maior sua atividade, maiores os seus níveis (Valls-Lacalle et al., 2016).

Neste contexto de desequilíbrio de aumento da concentração de EROs em relação aos antioxidantes endógenos, o resultante dano oxidativo é uma das principais causas da patologia associada à injúria da isquemia e reperfusão em mamíferos não tolerantes à privação de $\mathrm{O}_{2}$, tendo a mitocôndria como a principal fonte de EROs (Honda et al., 2005; Lisa e Bernardi, 2006). Interessantemente, enzimas antioxidantes como SOD (que dismuta o íon superóxido em $\mathrm{H}_{2} \mathrm{O}_{2}$ ), catalase (peroxidase que cliva $\mathrm{H}_{2} \mathrm{O}_{2}$ em água e oxigênio), glutationa peroxidase (GPx) (peroxidase que utiliza glutationa como co-substrato na conversão de peróxidos orgânicos e inorgânicos em água), tem seus níveis de atividade quanto proteicos depletados durante flutuações drásticas da disponibilidade de $\mathrm{O}_{2}$ (Singh et al., 1993; Slekel et al., 1999; Agardh et al., 2006). O estresse oxidativo neste contexto é quantificado também por moléculas que sofreram modificações oxidativas por EROs, por exemplo, fosfolipídeos 
oxidados geram aldeídos como o malonaldeído, 4-hidroxinonenal (4-HNE) (produtos finais de peroxidação lipídica), e um dos indicadores de oxidação de proteínas nas quais apresentam grupos carbonil (tidas como proteínas carboniladas), ambos os marcadores de estresse oxidativo aumentam durante o evento da isquemia e reperfusão em tecidos de camundongos (Ayene et al., 1992; Eaton et al., 1999). Porém os níveis destes parâmetros de estrese oxidativo se mantém inalterados em espécies que toleram a reduzida disponibilidade de $\mathrm{O}_{2}$ e sua posterior reoxigenação (Willmore e Storey, 1997; Welker et al., 2012).

Logo, tecidos de mamíferos quando submetidos à privação de $\mathrm{O}_{2}$ sofrem fortes lesões oxidativas mediadas por EROs, sendo que em humanos, segundo a Organização Mundial de Saúde (OMS) em 2012, a estimativa do número de mortes por doenças isquêmicas foi de 14,1 milhões em todo o mundo (OMS, 2016). Porém há exemplos de animais que passam por privação de $\mathrm{O}_{2}$ e o estresse da reoxigenação sem danos aparentes (Hermes-Lima e Zenteno-Savín, 2002; Welker et al., 2012). Uma das formas que estes animais tem como resposta adaptativa frente à falta de oxigênio é a redução dos processos que consomem ATP, chamada de depressão metabólica, envolvendo a redução da atividade da bomba de sódio e potássio ATPase, redução global da síntese proteica, reduzindo as taxas teciduais de consumo de $\mathrm{O}_{2}$, ativação de rotas anaeróbicas produtoras de ATP, através da produção de lactato por lactato desidrogenase (Hochachka et al., 1996, Hochachka e Lutz, 2001). Adendo à depressão metabólica, animais de vida aeróbia, que têm como história natural de vida a passagem por mudanças drásticas na disponibilidade de $\mathrm{O}_{2}$ respondem a este insulto por meio da supra-regulação de antioxidantes endógenos, como forma de defesa ao estresse oxidativo (Hermes-Lima et al., 1998; Hermes-Lima e Zenteno-Savín, 2002). Parece que os antioxidantes têm sua importância frente à falta de $\mathrm{O}_{2}$, pois no estado de depressão metabólica, no qual ocorre à redução global da síntese de proteínas, as enzimas antioxidantes continuam com atividade mantida ou aumentada, assim como os níveis proteicos.

Há inúmeros exemplos em animais que respondem a baixa dos níveis de $\mathrm{O}_{2}$ com aumento dos níveis de antioxidantes, sejam enzimáticos, com aumento dos seus níveis ou através do aumento de atividade antioxidante (incluindo SOD, catalase, glutationa S transferase (GST), GPx, peroxiredoxina (PRx)), ou não-enzimáticos, 
com maiores níveis de síntese de metabólitos, incluindo glutationa (GSH), ascorbato e metalotioneina, bem como a resposta de genes (para enzimas antioxidantes) e fatores de transcrição envolvidos na resposta antioxidante (p.ex. fator induzido por hipóxia (HIF), nuclear fator eritroide 2 (Nrf2), forkhead box (FOX), ambos regulam genes antioxidantes entre outros sistemas envolvidos na adaptabilidade celular (Welker et al., 2013; Hermes-Lima et al., 2015; Moreira et al., 2016). Logo, os antioxidantes parecem ter uma importância adaptativa frente à privação de $\mathrm{O}_{2}$ na defesa contra $\mathrm{o}$ excesso da geração de EROs. Mas será que esta resposta adaptativa faz parte de qualquer espécie animal que tem como história natural de vida passagens por alteração da disponibilidade de oxigênio como a hipóxia ou anóxia? Esta resposta, avaliada em condições controladas de laboratório (ao submeter animais de respiração aquática à exposição aérea) foi observada em 100\% dos casos de animais cuja história natural de vida se adaptou a viver (ou sobreviver) na zona entre marés (ambiente altamente hostil) (Moreira et al., 2016). Apesar de não serem muitos os estudos sobre a resposta antioxidante na exposição aérea, estes estudos foram compilados por uma meta análise (ver capítulo 2 desta dissertação), mostrando que todos os animais apresentavam pelo menos uma enzima ou metabólito com seus níveis de atividade ou concentração, ou gene aumentados nesta condição (Moreira et al., 2016).

No ambiente entre marés, animais sesseis como mexilhões têm que lidar com ciclos de emersão aérea e submersão aquática. A descida da maré expõe os animais ao ar, privando-os de oxigênio da água, e posteriormente com a subida da maré, os animais são reimersos. Estes eventos cíclicos (intermitentes) de retirada e oferta de oxigênio podem acontecer por duas vezes em um período de 24 horas, podendo ser considerado um ritmo circadiano ou circatidal (Tessmar-Raible et al., 2011), e um exemplo natural de "isquemia e reperfusão" na natureza. E sabe-se que espécies residentes neste ambiente, mexilhões, ficam em estado de hipoxemia durante a exposição aérea (Gracey et al., 2012; Fields et al., 2014). Além disto, estes animais precisam suportar mudanças de temperatura ambiental, principalmente por serem ectotérmicos, no qual se espera que sua temperatura corpórea acompanhe a do ambiente, e dependendo do tempo de exposição aérea, os animais podem sofrer (espera-se) déficit hídrico nas horas mais quentes do dia, como eles respondem a esta situação de estresse ambiental? Como enfrentar fisiologicamente este ambiente 
altamente hostil? Ainda durante a exposição aérea, metabólitos e produtos nitrogenados que seriam excretados durante a fase de reimersão, se acumulam no seu interior (Bayne et al., 1976).

Boa parte dos estudos neste contexto submete os animais apenas a um ou outro fator abiótico em separado, em condições artificiais de laboratório. Na zona entre marés, vários fatores abióticos podem atuar em conjunto, o que torna a visão ecológica e bioquímica altamente complexa, o que pode tornar os achados encontrados em laboratório um pouco distante do realismo fisiológico encontrado na natureza (Tomanek e Somero, 1999; Connor e Gracey, 2011; Spicer, 2014). A hipótese deste trabalho é que frente à exposição aérea, os mexilhões teriam seus antioxidantes supra-regulados, como parte do seu sucesso de adaptabilidade ambiental, devido ao esperado desequilíbrio redox promovido pelos agressores ambientais, como observado em estudos frente à privação de oxigênio (Welker et al., 2013; Hermes-Lima, 2015), estresse térmico (Hofmann e Somero, 1999), já que o aumento da temperatura ambiental em diferentes espécies de ectotérmicos marinhos promove aumento da produção de EROs, gerando estresse oxidativo (Abele et al. 2002; Lesser, 2006), assim como a hipóxia e o estresse da reoxigenação (Welker et al., 2016). Este mecanismo de aumento das defesas antioxidantes foi nomeado de 'preparo para o estresse oxidativo'(Hermes-Lima e Storey, 1998), pois na época os autores imaginavam que a resposta antecipada pelos antioxidantes quando submetidos à privação de $\mathrm{O}_{2}$ seria para os níveis aumentados de EROs na reoxigenação (HermesLima e Storey, 1998), mas esta ideia foi revista, e os autores sugerem que na hipóxia ocorre aumento de EROs e os animais respondem a este aumento através das defesas antioxidantes (Hermes-Lima et al., 2015).

Porém ainda não foi completamente elucidado se nos animais tolerantes a falta de $\mathrm{O}_{2}$ ocorre aumento de EROs quando submetidos a mudanças da indisponibilidade de $\mathrm{O}_{2}$ (hipóxia, anóxia), e evidências sugerem que não em tartarugas da espécie Trachemys scripta submetidas à anóxia por diferentes períodos, entre uma e quatro horas (Milton et al., 2007). Na espécie de platelminto Macrostomum lignano submetido à anóxia por uma hora e meia houve queda dos níveis de superóxido no grupo anóxia em relação ao grupo de animais mantidos em normóxia (RiveraIngraham et al., 2013a). Na espécie de mexilhão Mytillus edulis submetido à anóxia 
por 48 horas também não houve aumento da produção de superóxido (RiveraIngraham et al., 2013b), e no bivalve Ártica islandica tanto na hipóxia (2 horas) quanto na reoxigenação ocorre baixa dos níveis de superóxido (Strahl et al., 2011). Mas ainda é uma questão em aberto já que algumas das sondas utilizadas por RiveraIngraham (2013a) e Strahl et al., (2011) não serem específicas para EROs apenas (Kalyanaraman et al., 2012), apesar dos tecidos animais dos platelmintos submetidos à anóxia e incubados com SOD exógena terem o sinal da produção de superóxido diminuído em relação aos animais em normóxia, ou até mesmo diminuído em relação ao grupo de animais que também teve diminuído o sinal para o superóxido em resposta à anóxia (Rivera-Ingraham et al., 2013a).

Não obstante, foi observado que mudanças de expressão de genes antioxidantes em resposta à exposição aérea no ambiente entre marés foram supraregulados, na espécie de mexilhão Mytillus Californianus, genes para glutationa $\mathrm{S}$ transferase (GST) (envolvida no metabolismo de xenobióticos), GPx e peroxiredoxina (Prx), peroxidase que utiliza tioredoxina como co-substrato) (Gracey et al., 2008). Mas a relação de altos níveis de expressão de genes, ou proteínas não necessariamente resulta em ganho de atividade funcional enzimática (Czaha et al., 1994), pois a nível de resposta imediata ao estresse oxidativo, envolvendo o controle fisiológico dos níveis de EROs ocorre por meio da atividade enzimática antioxidante (Weydert e Cullen, 2010), ou das moléculas antioxidantes que neutralizam e mantém EROs em níveis fisiológicos (Wu et al., 2004).

A novidade do projeto apresentado no capítulo 1 desta dissertação é a realidade fisiológica dentro do ambiente natural, onde estas espécies de mexilhões sesseis vivem, persistem, lutam pela sobrevivência no ambiente entre marés. Como estes animais lidam com o suposto aumento de EROs durante os ciclos de baixa e alta das marés? Neste trabalho foi analisado um dos principais antioxidantes endógenos em animais, a glutationa (GSH), na espécie de mexilhão que vive em região entre marés Mytilaster solisianus, durante ciclos naturais de marés em Penha, Santa Catarina (Brasil). A investigação de GSH (L-gama-glutamil-L-cisteinil glicina) foi escolhida por ser um dos principais antioxidantes em células animais (assim como em vegetais e fungos), possui um par redox, a reduzida (GSH), que ao ser oxidada produz a glutationa dissulfeto (GSSG), esta pode ser reciclada a GSH de novo por glutationa 
redutase (GR), na presença de NADPH (Lushchak, 2011). Em mamíferos a forma reduzida pode atingir entre 1-8 $\mathrm{mM}$ de concentração, funcionando como um tampão redox (Griffith, 1999). É altamente compartimentalizada no núcleo e mitocôndria, sendo importante para o homeostase redox destas organelas quando submetidas a estresse oxidativo (Marí et al., 2009; Hatem et al., 2014). Participa também na regulação funcional de proteínas por modificação pós-traducional (S-glutationilação) (Mailloux e Willmore, 2014), transporte de aminoácidos, regulação do correto dobramento de proteínas no retículo endoplasmático pelo fornecimento de enxofre pela forma dissulfeto (Chakravarthi et al., 2006). E em relação à anóxia artificial, por seis dias, no gastrópode marinho de região entre marés Littorina littorea, houve aumento nos níveis de GSH de 2,8 vezes (Pannunzio e Storey, 1998). Será que esta resposta à privação de $\mathrm{O}_{2}$ envolvendo GSH também ocorre em Mytilaster solisianus em condições naturais do campo?

\section{OBJETIVOS}

Avaliar mudanças no sistema antioxidante e no metabolismo de radicais livres em mexilhões Mytilaster solisianus expostos à exposição aérea no seu ambiente natural de região entre marés. Tal investigação deu origem ao manuscrito apresentado no capítulo 1 desta dissertação.

Realizar uma meta-análise e uma revisão da literatura sobre as respostas no reino animal do sistema antioxidante (envolvendo enzimas e moléculas de baixo peso molecular) em diferentes situações de privação de $\mathrm{O}_{2}$, como hipóxia, anóxia, exposição aérea, congelamento, dessecamento. Tal investigação deu origem ao artigo aceito para publicação e apresentado no capítulo 2 desta dissertação. 


\section{CAPÍTULO 1 - MANUSCRITO 1: METABOLISMO DA GLUTATIONA NO MEXILHÃO MYTILASTER SOLISIANUS (MYTILIDAE) EM CICLOS NATURAIS DE MARÉS}

\section{INTRODUÇÃO}

Em geral, tecidos de mamíferos submetidos à privação e reintrodução de oxigênio $\left(\mathrm{O}_{2}\right)$ sofrem fortes lesões oxidativas mediadas por EROs. Em humanos, segundo a Organização Mundial de Saúde (OMS) em 2012, a estimativa do número de mortes por doenças isquêmicas foi de 14,1 milhões em todo o mundo (OMS, 2016). Porém, há exemplos de animais que passam por privação de $\mathrm{O}_{2}$ e o estresse da reoxigenação sem sofrerem danos aparentes (Hermes-Lima e Zenteno-Savín, 2002; Welker et al., 2012). Há inúmeros exemplos de animais que respondem à diminuição dos níveis de $\mathrm{O}_{2}$ com aumento dos níveis de antioxidantes. Por exemplo, ocorre aumento dos níveis de expressão de genes que expressam proteínas com função antioxidante, níveis de proteína ou metabólitos antioxidantes, e níveis de atividade enzimática antioxidante (Welker et al., 2013; Hermes-Lima et al., 2015; Moreira et al., 2016). Os antioxidantes são regulados de modo a conter os radicais livres e EROs gerados durante os momentos de privação e reintrodução de $\mathrm{O}_{2}$. Nossa ideia é saber se o fenômeno do preparo para o estresse oxidativo (POS) (Hermes lima et al., 2015) está presente em animais que vivem na zona entre marés. Para isto, usamos o princípio de August Krogh: para cada problema fisiológico existe uma espécie modelo que pode ser estudada de modo mais conveniente (Krebs, 1975). Neste caso, nos interessou uma espécie séssil de mexilhão que fica exposta ao ar durante a baixa da maré e privada do $\mathrm{O}_{2}$ da água (devido ao fato de sua respiração ser aquática). Atualmente, este fenômeno bioquímico do POS envolvendo os antioxidantes foi listado com um grande número de animais de diferentes filos, desde invertebrados a vertebrados (Moreira et al., 2016). Aqui, foram avaliadas mudanças no sistema antioxidante e no metabolismo de radicais livres através da medição dos níveis de um dos principais antioxidantes encontrados em animais, a glutationa (GSH), em diferentes momentos do regime entre marés, no qual ocorrem eventos cíclicos de retirada e oferta de $\mathrm{O}_{2}$. 
Parte dos resultados das coletas I e II apresentados neste capítulo foram reportados no congresso realizado no México em Novembro de 2015, na "Second International conference on oxidative stress in aquatic ecosistems". Neste capítulo, também foram adicionados resultados de outra coleta realizada em maio de 2015, e foi apresentada no congresso regional da Federação de Sociedades de Biologia Experimental (FeSBE) em maio de 2016 em Natal (Pará) pelo Dr. Orlando, no qual ajudou na coleta de número III.

\section{OBJETIVO}

Quantificar os níveis de GSH em mexilhões Mytilaster solisianus em resposta à exposição aérea no seu ambiente natural de região entre marés.

\section{MATERIAL E MÉTODO}

\subsection{COLETA DOS ANIMAIS}

Os mexilhões foram coletados no litoral de Penha, praia do trapiche, Santa Catarina. Foram realizadas três coletas, a primeira expedição nos dias 1 e 2 de novembro de 2014, nomeadas de coletas I e II, e a coleta III no dia 9 de maio de 2015. Na coleta I, os animais foram coletados de 6:30 até 21:10. Na coleta II, os animais foram coletados de 6:30 até 21:25. Na coleta III, os animais foram coletados de 7h00 e 18h30. Foram registradas durante o período de coleta as temperaturas da água e ar com termômetro de mão. A espécie estudada Mytilaster solisianus possui licença ambiental com finalidade científica pelo ICMBio e SISBIO (número 20030-9). Por se tratar de uma espécie de invertebrado, não foi necessário comitê de ética. A espécie foi identificada por mim e pelo especialista em moluscos Dr. Luiz Ricardo Lopes de Simone (Universidade de São Paulo).

A escolha dos dias de coleta dos animais foi baseada na tábua das marés, no

site da Marinha Brasileira (http://www.mar.mil.br/dhn/chm/box-previsaomare/tabuas/), como forma de prever marés que fossem interessantes para a realização da coleta, incluindo altura da maré, tempo de maré baixa, o clima e tempo favoráveis 
à realização da coleta, tentando evitar períodos de chuva. A seguir, tábua das marés (Fig. 1) para a primeira, segunda e terceira coleta, especificando momentos de maré alta e baixa, e foi observado que na rocha no qual os animais foram coletados eles ficaram emersos a partir da maré 0.5 :

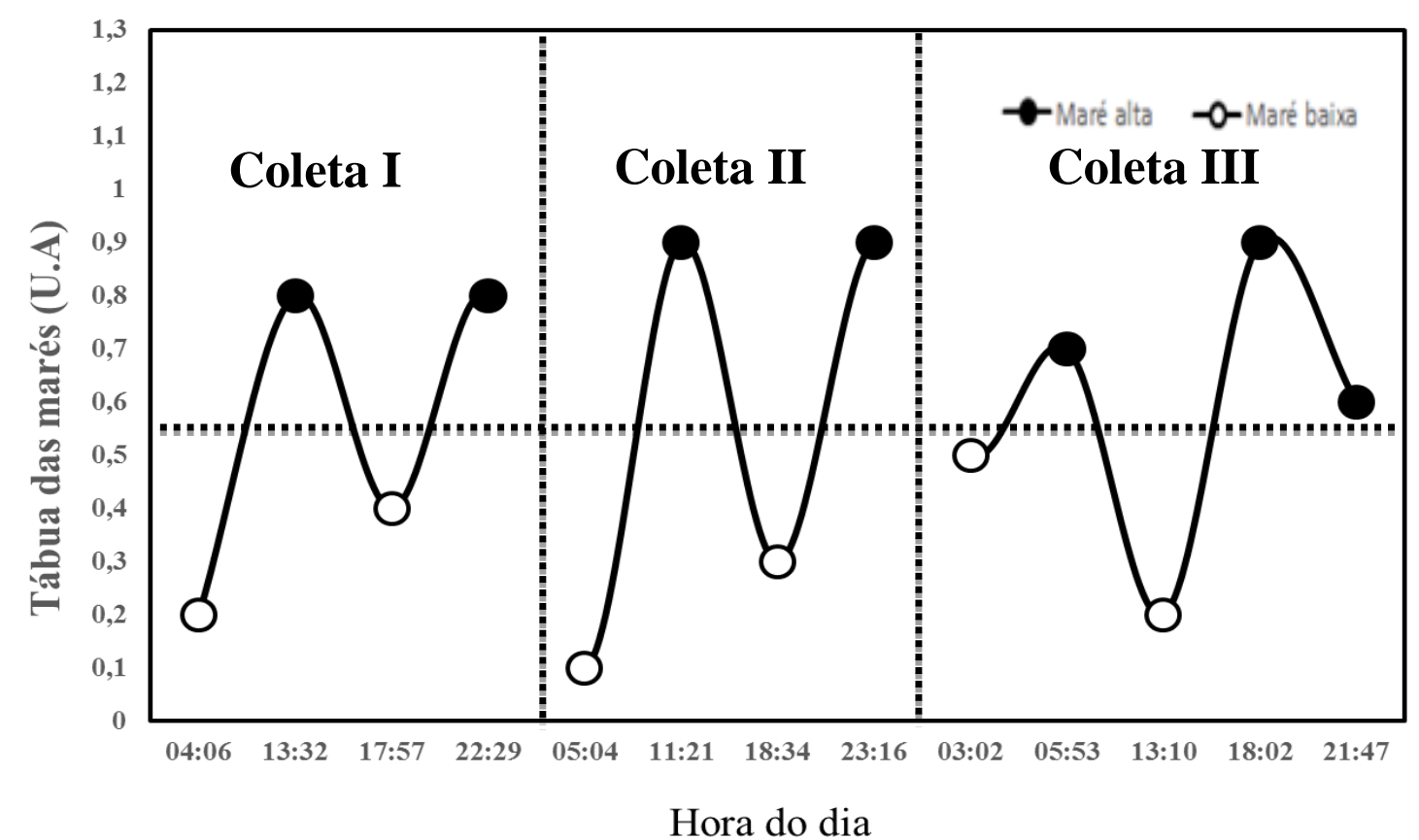

Figura 1. Tábua das marés (u.a. unidade arbitraria) para as três coletas: coleta I no dia 1 de novembro de 2014 à esquerda; coleta II no dia 2 de novembro de 2014 ao centro da figura; e coleta III no dia 09 de maio à direita. São mostrados os horários/momentos em que a maré alta se encontra no seu pico, e momentos em que a maré se encontra mais baixa. Fonte: Tábua das Marés, Marinha do Brasil 〈http://www.mar.mil.br/dhn/chm/box-previsao-mare/tabuas/>.

Os animais eram retirados da rocha (45 animais) com pinça ou com as próprias mãos, levados até a praia em uma bandeja plástica com água (no caso de animais coletados imersos) ou seca (no caso de animais coletados emersos), limpos em papel, colocados em microtubos de $2 \mathrm{~mL}$ (três animais por tubo) e em seguida congelados em gelo seco. Após todos os animais serem colocados em gelo seco ( $-80^{\circ}$ C), estes eram guardados em nitrogênio líquido $\left(-195,79^{\circ} \mathrm{C}\right)$, sendo que o tempo entre a retirada dos animais da pedra e a guarda destes no nitrogênio líquido era de até 10 minutos. Este procedimento também é adotado por outros pesquisadores (Gracey et 
al., 2008; Dowd et al., 2013). O nitrogênio líquido ficava em um local sombreado não muito distante, para evitar sua rápida evaporação. A coleta era feita por mim e mais duas pessoas (Daniel Carneiro Moreira e Leonardo Rios).

A coleta 3 ocorrida em maio seguiu o mesmo princípio, porém, 90 animais foran pegos durante o regime da maré e quatro pessoas realizaram a coleta (Igor Santos, Leonardo Rios, Orlando Vieira, e eu). No anexo A, há o registro de fotos durante o momento em que os animais se encontram reimersos e a rocha na qual os mesmos foram coletados.

No momento da retirada dos animais, era observado se estes possuíam bisso, estrutura que deixa os animais fixos à rocha, como forma de avaliar a viabilidade dos animais. Os animais que eram retirados facilmente da rocha eram desprezados por estarem mortos (o que era constatado com sua abertura). A seguir, imagem com os animais na bandeija e na figura ao lado, seta apontando para o biço:

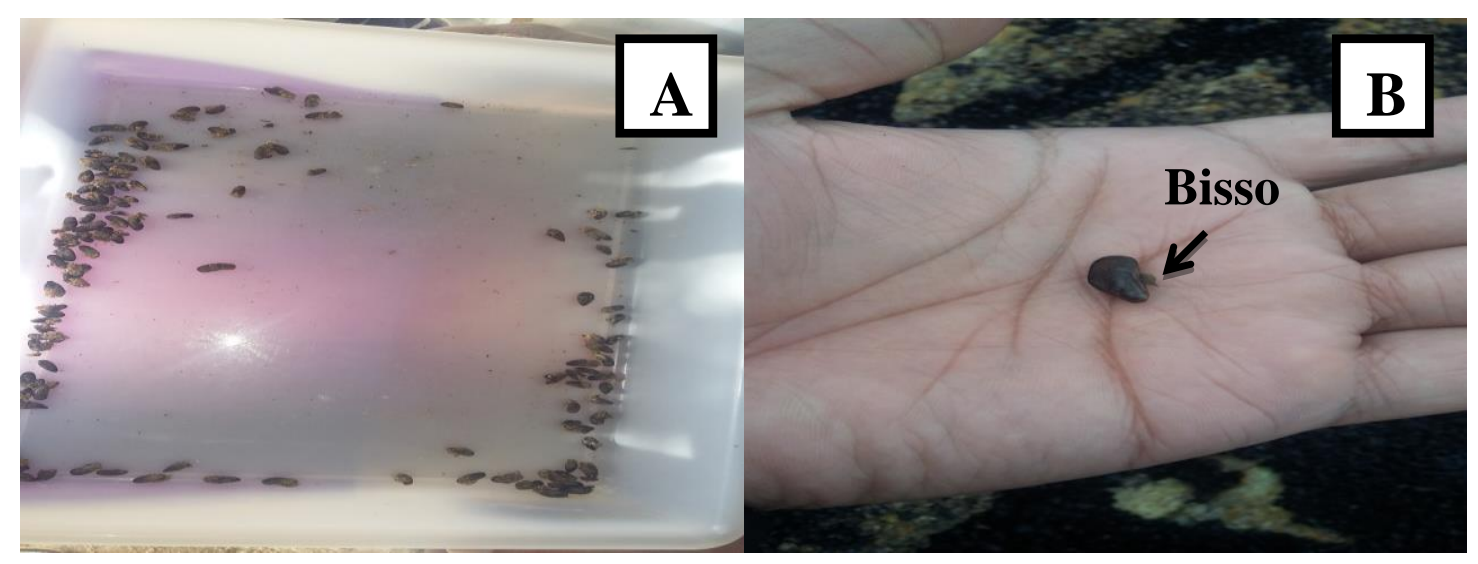

Figura 2. A. Coleta de mexilhões durante a exposição aérea. B. Seta apontando para o bisso.

Além disto, grupos de animais pegos aleatoriamente eram abertos manualmente e observados, como outra forma de avaliar se eles estavam vivos. Nos animais vivos, foi observada a presença de água dentro destes, seja nos animais imersos ou durante a emersão. Durante a exposição aérea, observou-se que os animais ficam com sua concha fechada, e durante o período de reimersão, eles tinham sua concha levemente aberta. Também foi constatado que, mesmo após muitas horas de exposição aérea, havia a presença de água no interior dos mexilhões. 
Chegamos à praia às 5 horas da manhã. Às 5h:30min, começamos a contar no relógio o tempo que os animais estavam expostos ao ar na maré baixa com absoluta certeza. Ao chegar à praia, os animais já estavam passando por uma maré baixa noturna (que terminou ao final da manhã) e alguns já estavam emersos. Portanto, os tempos de reimersão e exposição aérea para os animais foram baseados a partir da retirada dos primeiros animais.

Às 06:30 (uma hora, pelo menos, de exposição aérea), foram coletados 45 animais, e após mais uma hora, a mesma quantidade. Após este último ponto de coleta, a maré começou a banhar os animais, período inicial do retorno à água. Entretanto, o retorno da maré não é brusco, e sim intermitente, ou seja, ela retorna aos poucos, de modo que foi necessário estabelecer uma regra: enquanto a água não molhasse os animais com certo grau de frequência, de minuto em minuto, os animais ainda não eram considerados completamente reimersos. A partir daí, o tempo de início da reimersão era contado (tempo zero) e a hora da reimersão registrada. O momento de considerar a exposição aérea também foi estabelecido, levando em conta o tempo no qual os animais pararam de ser definitivamente banhados pela água.

Nas coletas I e II, os tempos de retirada dos animais foram similares. Os tempos experimentais foram: pelo menos uma e duas horas de exposição aérea; uma, duas, três, cinco e 7 horas de reimersão; 30 minutos, 2, 3 e 4 horas de exposição aérea. Após 4 horas de exposição aérea, começou a chover e decidiu-se não coletar mais animais no tempo de reimersão, pois havia risco da força da água sobre os experimentadores no campo, com a ocorrência de raios perto da localidade.

A coleta III foi realizada do mesmo modo, porém, para testar a hipótese de que quanto maior o tempo de exposição aérea, maior seria o estresse fisiológico sofrido pelos mexilhões, fizemos coletas a mais. Isto porque os animais ficariam em um maior tempo sem acesso ao alimento, maior tempo privado de oxigênio da água, implicando em maior intensidade de hipoxemia fisiológica. Além disto, dependendo das condições do clima, com o aumento da temperatura, poderia se esperar tanto maior estresse termal, quanto maiores taxas de evaporação da água corpórea dos animais, intensificando o déficit hídrico destes, e com a elevação termal. Por se tratarem de animais ectotérmicos, a temperatura corporal acompanha a temperatura do ambiente, e sabe-se que elevações termais superiores ao limite termal fisiológico 
(específico de cada espécie) induzem estado de hipóxia em invertebrados ectotérmicos (Anestis et al., 2007). Deste modo, foi escolhida uma maré diurna, onde os fatores abióticos pudessem potencializar um forte estresse fisiológico nos animais.

Assim, neste cenário ideal de intenso estresse fisiológico, mediado por múltiplos agentes estressores do ambiente, buscou-se um período de maré na fase de lua cheia, com uma mais duradoura. A coleta dos animais se deu na mesma pedra da praia da coleta I e II, local em que os primeiros animais foram coletados. Apesar de a tábua das marés ser apenas uma previsão (não necessariamente iria acontecer do jeito que foi predito), a coleta foi bem sucedida. A expectativa inicial era de que os animais ficassem 8 horas expostos ao ar, e ficaram expostos por 9 horas.

As mesmas regras de retirada dos animais estabelecidas na coleta I e II foram utilizadas na coleta III. Chegamos à praia por volta dàs 05:30. Às seis horas da manhã, começamos a cronometrar o tempo de permanência dos animais na água. $\mathrm{O}$ tempo de coleta dos animais foi: pelo menos uma e duas horas em água; duas, quatro, seis, 7,5, e 9 horas de exposição aérea; o tempo de reimersão começou no momento em que os animais começaram a ficar constantemente imersos por 5 minutos, uma e duas horas de reimersão.

Para fins de análises bioquímicas, foram escolhidos alguns pontos específicos durante o ciclo das marés. Nos parâmetros de GSH na coleta I e II, analisaram-se animais com pelo menos 2 horas de exposição ao ar; uma, três e 7 horas de reimersão; e 30 minutos e quatro horas de exposição aérea. Na coleta III, foram analisados animais imersos por pelo menos duas horas; duas, quatro e 9 horas de exposição aérea; e o tempo de 5 minutos, uma e duas horas de reimersão. Para cada experimento, sempre havia pelo menos um animal de cada grupo experimental, escolhido aleatoriamente. Os animais eram previamente pesados antes das análises, e tinham o seu tamanho (i.e. largura) registrado por paquímetro de mão.

A seguir, figura esquemática dos pontos experimentais das coletas I, II e III, e os grupos escolhidos (círculos) para fazer as análises dos parâmetros de GSH: 


\section{Coleta I e II}
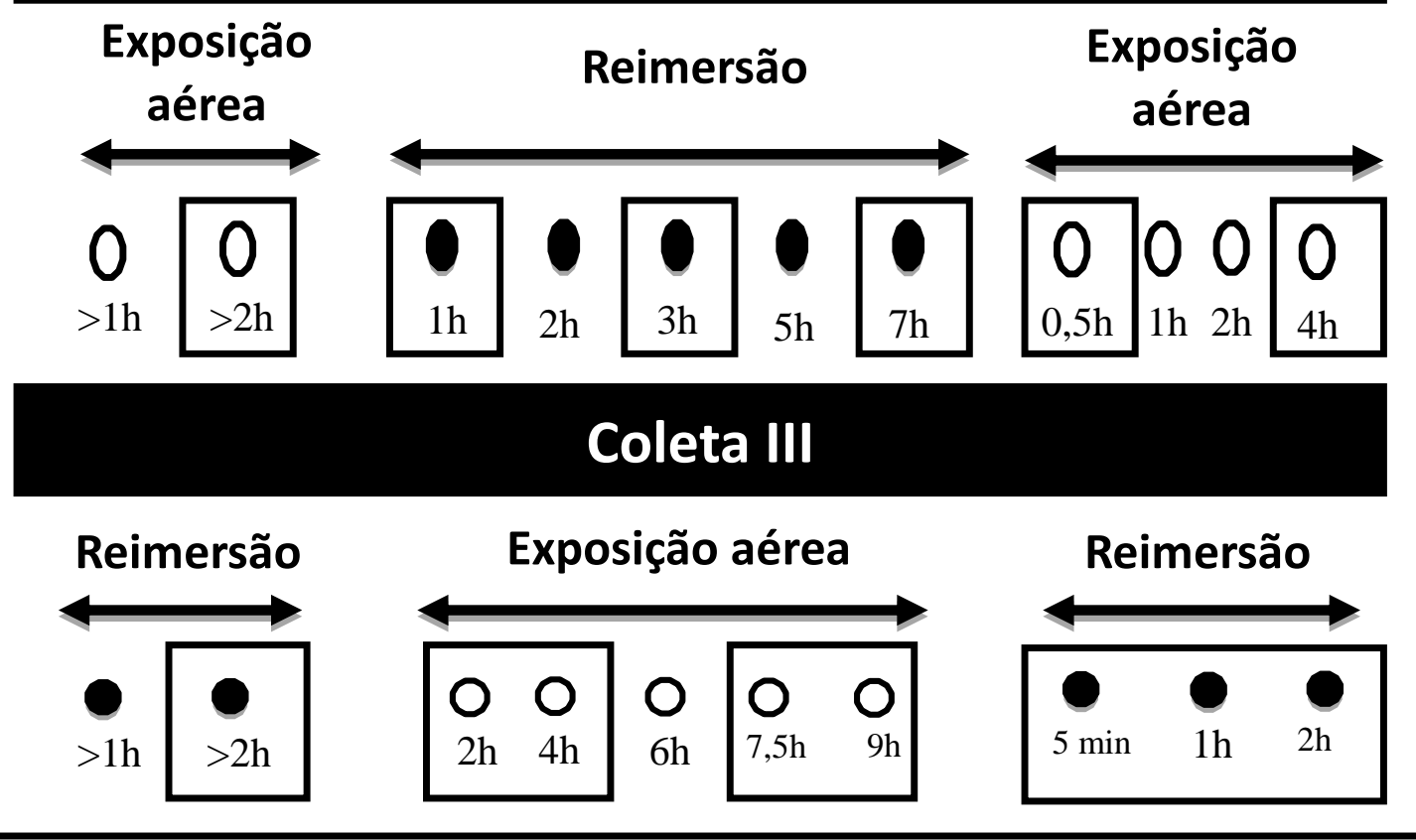

Figura 3. Grupos experimentais das três coletas. Os grupos destacados foram escolhidos para a realização das análises de GSH em homogenato de corpo inteiro nos mexilhões.

\subsubsection{NÍVEIS DE EQUIVALENTES DE GLUTATIONA (EQ-GSH)}

A concentração de glutationa total (Eq-GSH) ou equivalentes de GSH foi determinada através da reação entre os grupos sulfidrila de duas moléculas de GSH com uma molécula 5,5'-ditiobis-2-ácido nitrobenzóico (DTNB) (reagente de Ellmans), produzindo 5-tio-2-ácido nitrobenzóico (TNB) e GS-TNB, TNB tem pico máximo de absorção em 412nm (Rahman et al., 2006). O método se baseia no descrito por Akerboom e Sies (1981) e os passos dos procedimentos metodológicos para a medição dos níveis totais de glutationa e GSSG foram feitos de acordo com Welker (2009). O método envolve um sistema enzimático, pois o produto GS-TNB é reduzido pela presença de GR e NADPH, a GSSG presente na amostra animal também é reduzida formando duas moléculas de GSH, isto proporciona a 
especificidade do método para a medição dos níveis totais de GSH. Deste modo, EqGSH é a soma entre GSH e GSSG (Eq-GSH=GSH+2GSSG) (Griffith, 1980). Para a medição somente de GSSG, a GSH presente na amostra sofria derivatização, ou seja, era impedida de participar da reação por meio da sua reação com 2-vinilpiridina (2VP) (Griffith, 1980). Assim, analisavam-se tanto Eq-GSH quanto GSSG através das taxas de reação (abs/min) em $412 \mathrm{~nm}$, sendo proporcional a concentração destas moléculas (Griffith, 1980).

Abaixo, figura demonstrativa da reação:

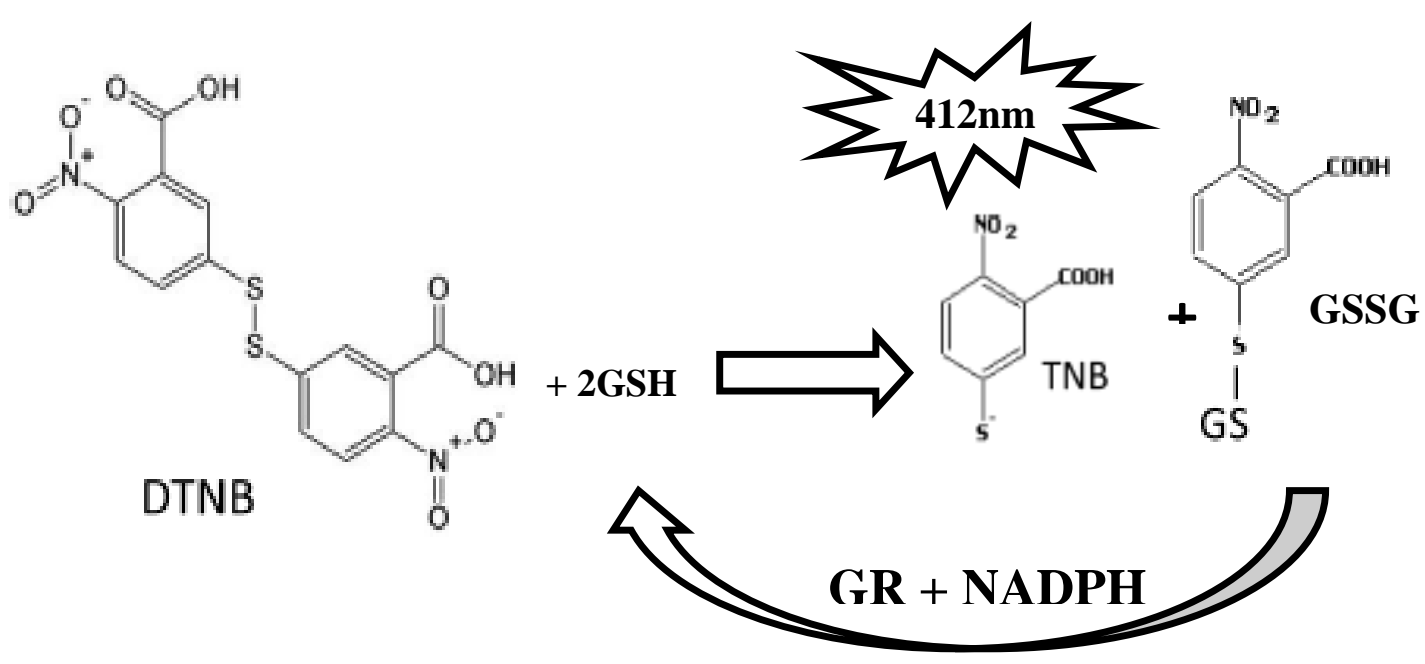

Figura 4. Reação entre DTNB e 2 moléculas de GSH, produzindo TNB (detectado em $412 \mathrm{~nm}$ ) e GS-TNB. Glutationa redutase (GR) reduz GS-TNB na presença de NADPH, e GSH é produzida novamente e retorna a participar da reação com DTNB, enquanto que GSSG presente na amostra também é biotransformada produzindo duas moléculas de GSH. Figura modificada de Rahman et al., (2006), e Caito e Aschner (2015).

\subsubsection{PROCESSAMENTO DAS AMOSTRAS}

As amostras de tecidos congeladas e previamente pesadas (dias antes das análises) tinham sua largura medida com paquímetro de mão no dia dos experimentos. Rapidamente, a amostra animal era quebrada em nitrogênio líquido em um almofariz de porcelana para posterior homogeneização, utilizando um 
homogeneizador de $3 \mathrm{~mL}$ (tubo e pistilo de vidro), mantido sempre em baixa temperatura (no gelo), numa diluição de 1:5 (peso/volume), considerando o corpo inteiro dos animais. A quebra dos animais em nitrogênio líquido facilitava a obtenção do extrato bruto, devido à presença da concha. No homogeneizador, eram adicionados ácido tricloroacético (TCA) e a amostra, de forma que a concentração de TCA final atingisse $10 \%(\mathrm{p} / \mathrm{v})$. O meio acidificado evita que a GSH seja oxidada, e inativa as enzimas que a degradam. A concentração de $10 \%$ para o TCA foi escolhida por promover completa precipitação das proteínas e adequada estabilidade de GSH (Welker et al., 2009). O tempo de preparo dos homogeneizados era registrado para cada amostra animal, sendo de até 5 minutos. Feito o extrato bruto, este era transferido para microtubos de $1,5 \mathrm{~mL}$, que eram centrifugados por 6 minutos a $10.000 x g$, sob baixa temperatura $\left(4^{\circ} \mathrm{C}\right)$. Seu sobrenadante era usado para a determinação da concentração de Eq-GSH e GSSG.

\subsubsection{PREPARO DE SOLUÇÃO PADRÃO DE GSH}

A solução padrão de GSH passava pelas mesmas etapas que as amostras. Esta solução continha ácido e etanol com concentrações finais iguais as das amostras (TCA 2,38\%, etanol 4,76\%). O uso de GSH tem a vantagem da concentração exata de GSH poder ser aferida de forma rápida e fácil. Era feita uma solução de GSH $200 \mu \mathrm{M}$ em TCA 10\%. Sua concentração exata era sempre medida, com pouca variação, dado empírico da solução estoque ficava entre 19-21 mM. Misturavam-se em placa de 96 poços (TPP), em um volume final de $200 \mu \mathrm{L}$, nas seguintes concentrações finais: GSH $20 \mu \mathrm{M}$ em TCA 1\%, tampão fosfato $200 \mathrm{mM}$ com EDTA 0,5 mM (pH 7,0), DTNB 0,1 mM. Água era utilizada para completar o volume final, no branco, TCA $1 \%$ era utilizada no lugar de GSH. A microplaca era agitada por 15 segundos, passados 2 minutos, esta era agitada novamente, e a absorbância em $412 \mathrm{~nm}$ era registrada. Para os cálculos, a leitura dos brancos era subtraída da leitura dos tubos testes e era usado o coeficiente de extinção milimolar do TNB de $14,15 \mathrm{mM}^{-1} \cdot \mathrm{cm}^{-1}$ $\left(25^{\circ} \mathrm{C}\right)$ (Eyer et al., 2003). A solução ácida de GSH passava então pelas mesmas etapas que as amostras, tendo seu $\mathrm{pH}$ neutralizado: $100 \mu \mathrm{L}$ eram misturados com 300 $\mu \mathrm{L}$ de tampão fosfato $0,5 \mathrm{M}$ pH 7,0 e $20 \mu \mathrm{L}$ de etanol. Esta solução padrão de GSH 
era então diluída para as concentrações desejadas (próximas das encontradas nas amostras) usando-se solução de TCA neutralizada da mesma forma que nas amostras (TCA 2,38\%; tampão fosfato $0,357 \mathrm{M}$; etanol 4,76\%). Também eram separados tubos para a medição dos níveis de GSSG, substituindo o etanol por 2-vinilpiridina (2-VP), as amostras eram incubadas por 1 hora no escuro, esta é a etapa que ocorre a derivatização de GSH. Além disto, a amostra dos mexilhões e a solução padrão eram centrifugadas novamente a $10.000 x \mathrm{xg}$ por 4 minutos $\left(4^{\circ} \mathrm{C}\right)$, pois no momento da adição do tampão no sobrenadante ácido, havia a formação de um precipitado branco, não se sabe o que era, mas houve a necessidade desta nova centrifugação.

\subsubsection{CURVA-PADRÃO E MEDIÇÃO}

O volume final nos poços era de $200 \mu \mathrm{L}$, e as concentrações do meio reacional eram: tampão fosfato $100 \mathrm{mM}$ (pH 7,0), EDTA $1 \mathrm{mM}$, TCA 0,238\%, GSH entre 0 e 1,5 $\mu \mathrm{M}$, NADPH 0,1 mM, DTNB $2 \mathrm{mM}$ e GR 0,05 U/mL. A curva de medição dos níveis de GSSG também era feita com GSH, e a concentração de GSH estava entre 0 e $0,2 \mu \mathrm{M}$, enquanto que a concentração final de GR era de $0,3 \mathrm{U} / \mathrm{mL}$ (Welker, 2009). Nos poços, os mesmos eram misturados na seguinte sequência de reagentes: tampão fosfato com EDTA, solução de TCA neutralizada (ou solução niveladora), solução padrão de GSH ou amostra neutralizada (volumes entre 3 e $12 \mu \mathrm{L}$ ), NADPH e DTNB. A reação se iniciava com GR, e as taxas (abs/min) em $412 \mathrm{~nm}$ eram registradas. Ao se fazer a curva-padrão, as amostras eram feitas logo em seguida.

\section{ESTATÍSTICA}

As diferenças estatísticas foram avaliadas após teste de normalidade e homocestidade entre grupos. Havendo tais premissas, os parâmetros de GSH foram avaliados utilizando a análise de variância fator único (ANOVA), com análise pós hoc (Tukey). Não havendo normalidade e homocesticidade, utilizava-se teste nãoparamêtrico. As análises foram feitas utilizando o software de estatística GraphPad. Foi considerando o grau de significância com $\mathrm{P}<0,05$. Os resultados estão apresentados como média \pm erro padrão. A quantidade de indivíduos ou (n) 
experimental variou entre seis e nove animais para cada grupo experimental analisado.

\section{RESULTADOS}

\subsection{REGISTRO DA TEMPERATURA AMBIENTE}

Durante a coleta dos animais, observou-se que a temperatura da água e ar na coleta I e II variaram entre 22,5 a $26^{\circ} \mathrm{C}$, na coleta 3 a variação da temperatura da água variou entre 19 e $23^{\circ} \mathrm{C}$, enquanto que a temperatura do ar variou entre 15 e $28^{\circ} \mathrm{C}$, ver figura a seguir:

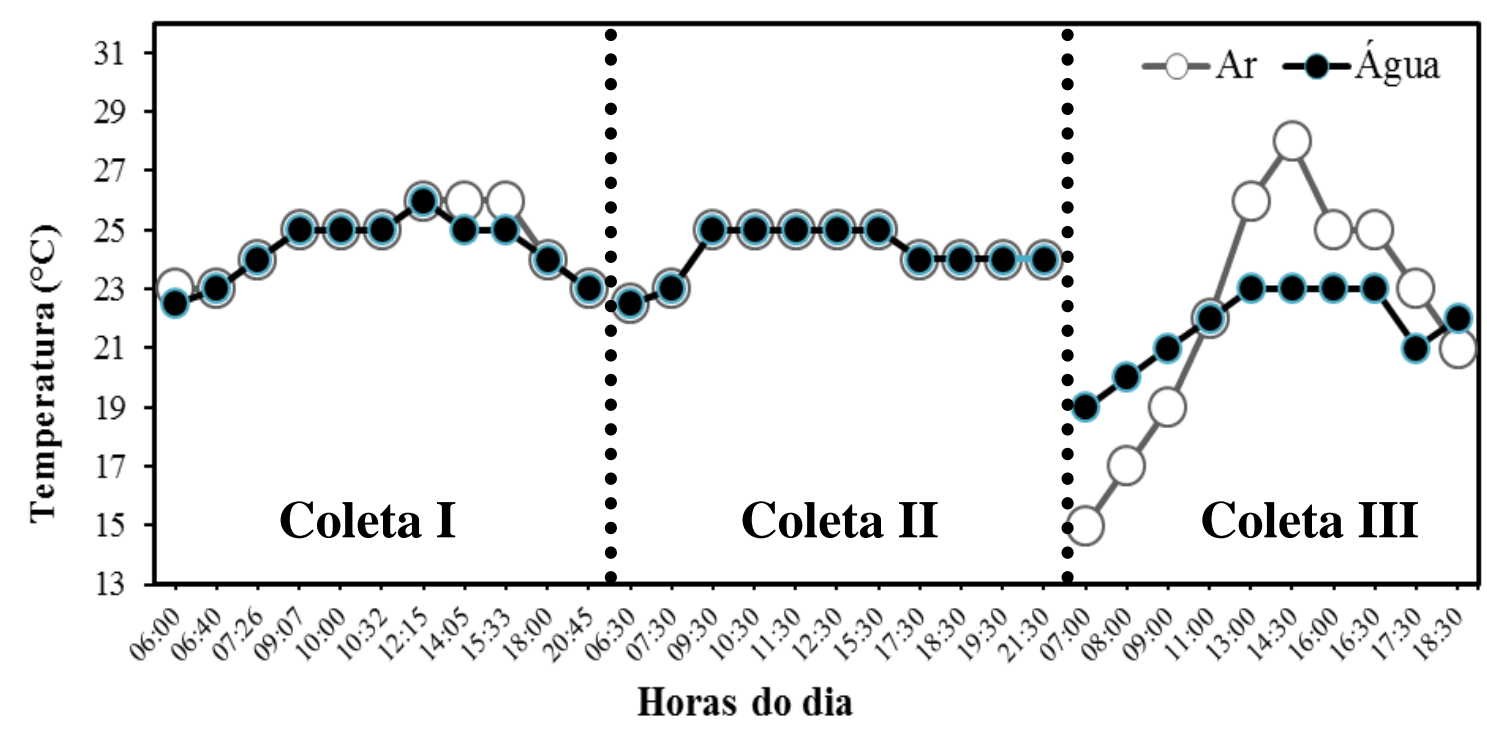

Figura 5. Registro da temperatura da água e ar ao longo das três coletas.

Especificamente para a coleta de número III, fez-se um gráfico mostrando a relação do momento inicial de baixa da maré até o seu retorno no final da tarde (ver figura no anexo).

\subsection{CURVA DE DISTRIBUIÇÃO (COMPRIMENTO E PESO)}

Antes de iniciar as análises, os animais tinham o seu peso registrado, e durante os experimentos, o seu tamanho também era medido. Assim, fez-se um perfil de curva de distribuição destas variáveis. Em um total de 146 animais, a média do comprimento dos animais foi de $0,71 \mathrm{~cm}$, com desvio padrão de $0,23 \mathrm{~cm}$, e amplitude de 17,55. Para o peso, a média foi de $235 \mathrm{mg}$, com desvio-padrão de 93,22 mg, e amplitude de 20,68, ver figura abaixo: 

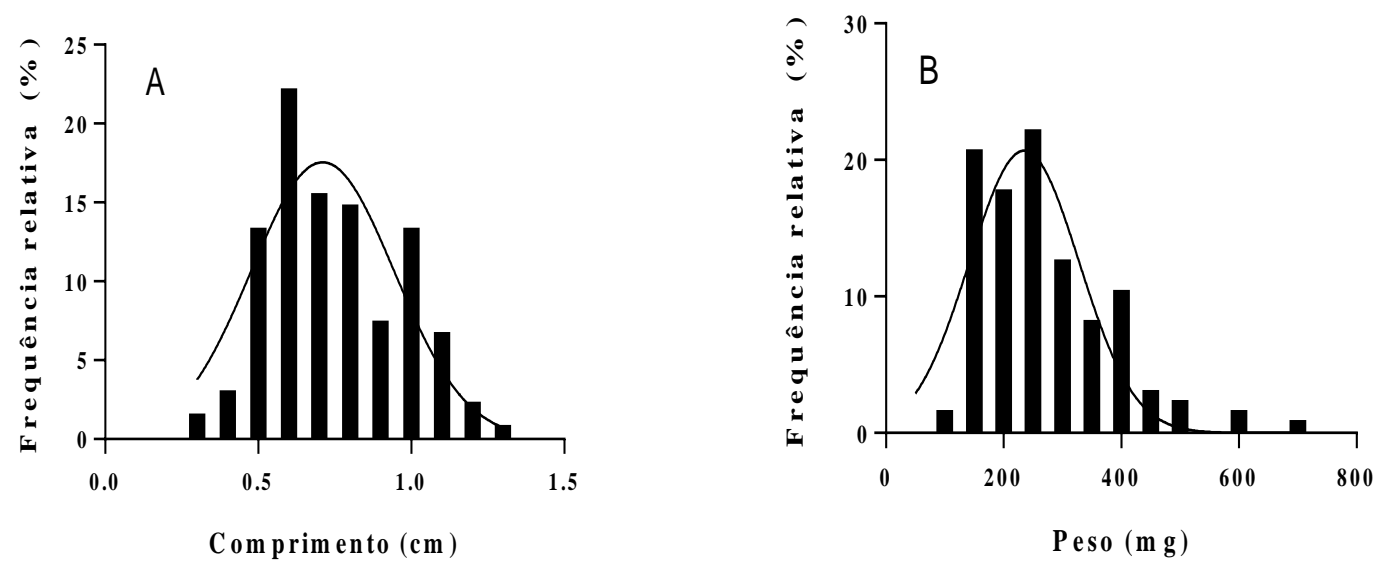

Figura 6. Dados de distribuição (\%) da largura $(\mathrm{cm})$ e peso dos mexilhões $(\mathrm{mg})$. $\mathrm{N}=146$ animais. A Comprimento dos animais (cm). B Peso dos animais (mg).

A seguir, realizou-se uma análise de regressão linear, relacionando as variáveis comprimento e peso. Houve correlação positiva entre tamanho e peso $(\mathrm{P}<0,001)$. Em muitos casos, os animais possuem o mesmo tamanho, porém, com pesos diferentes, mas a tendência é o aumento do peso com o tamanho, figura abaixo:

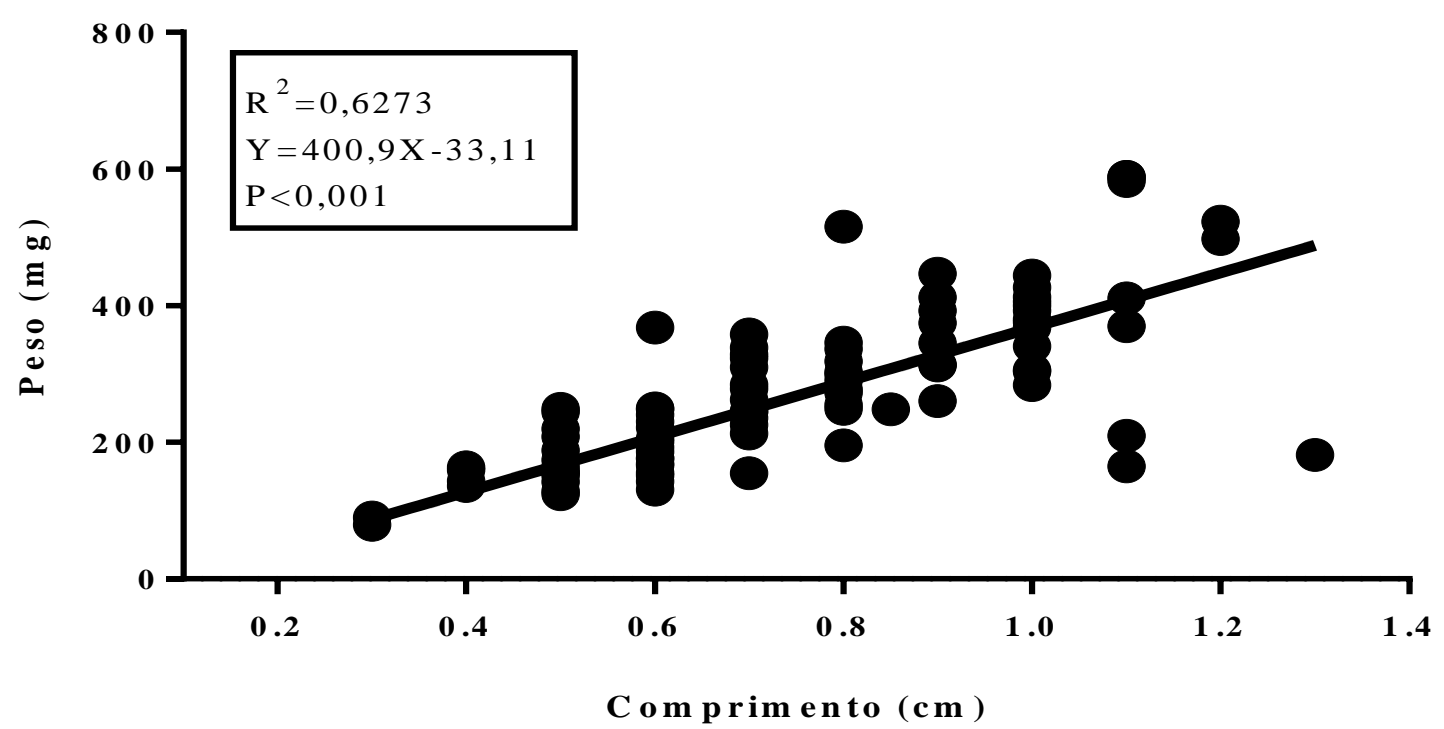

Figura 7. Regressão linear entre comprimento $(\mathrm{cm})$ e peso $(\mathrm{mg})$ nos mexilhões. $\mathrm{N}=146$ animais. 
Na coleta I e II, os níveis de Eq-GSH nos animais foram mantidos inalterados ao longo do ciclo das marés ( $\mathrm{P}=0,0664$ para a coleta I e $\mathrm{P}=0,4832$ para a coleta II). Na coleta III, houve uma queda nos níveis de Eq-GSH (42\%) após duas horas de exposição aérea em relação ao grupo de animais reimersos por mais de duas horas $(\mathrm{P}=0,050)$, ver a seguir:

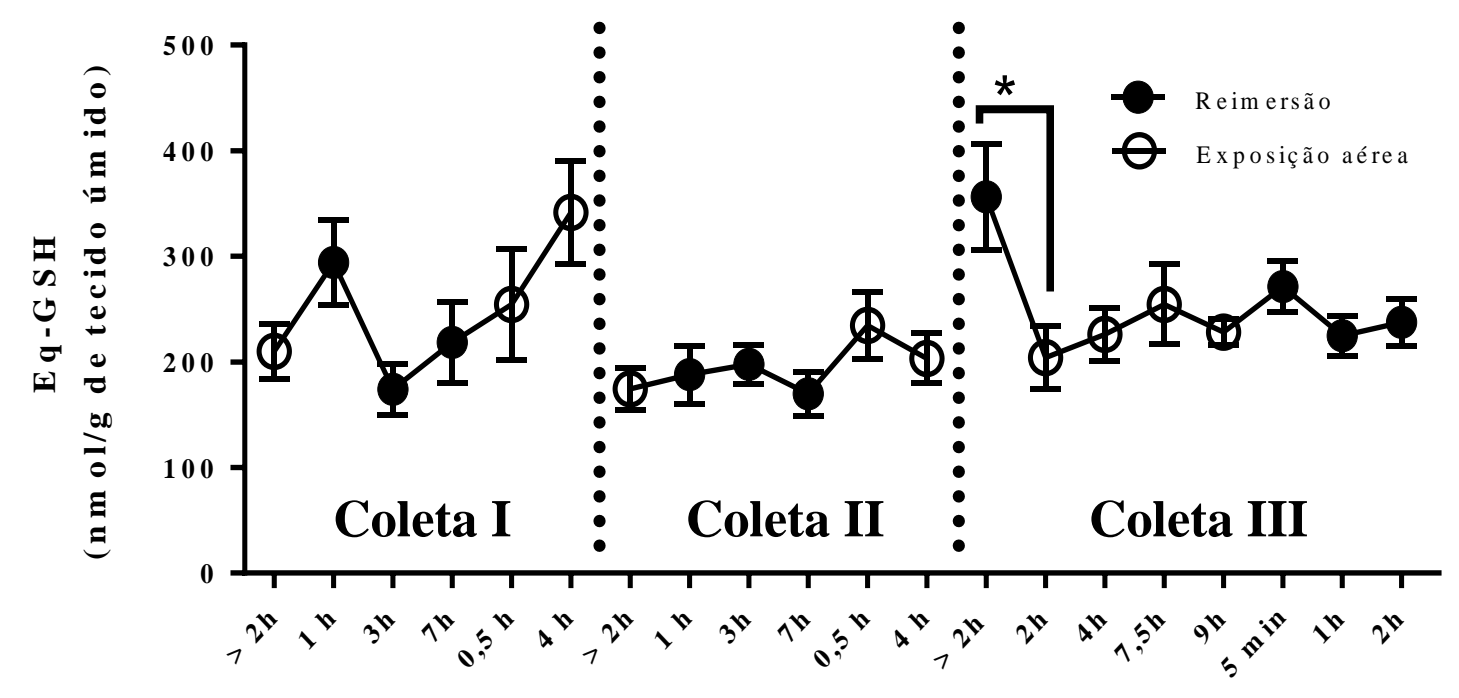

Tempo de exposição ( $m$ in ou horas)

Figura 8. Níveis totais de glutationa (Eq-GSH) nos mexilhões medidos nas três coletas durante a reimersão e exposição aérea. Dados dos níveis Eq-GSH da coleta I à esquerda, coleta II no centro, coleta III à direita. Dados representados com média e erro padrão da média. $\mathrm{N}=(6-9)$ animais por grupo experimental. * Diferença significativa $(\mathrm{P}=0,050)$.

Não houve diferença nos níveis de GSH na coleta I, II e III (P>0,05), ver figura: 


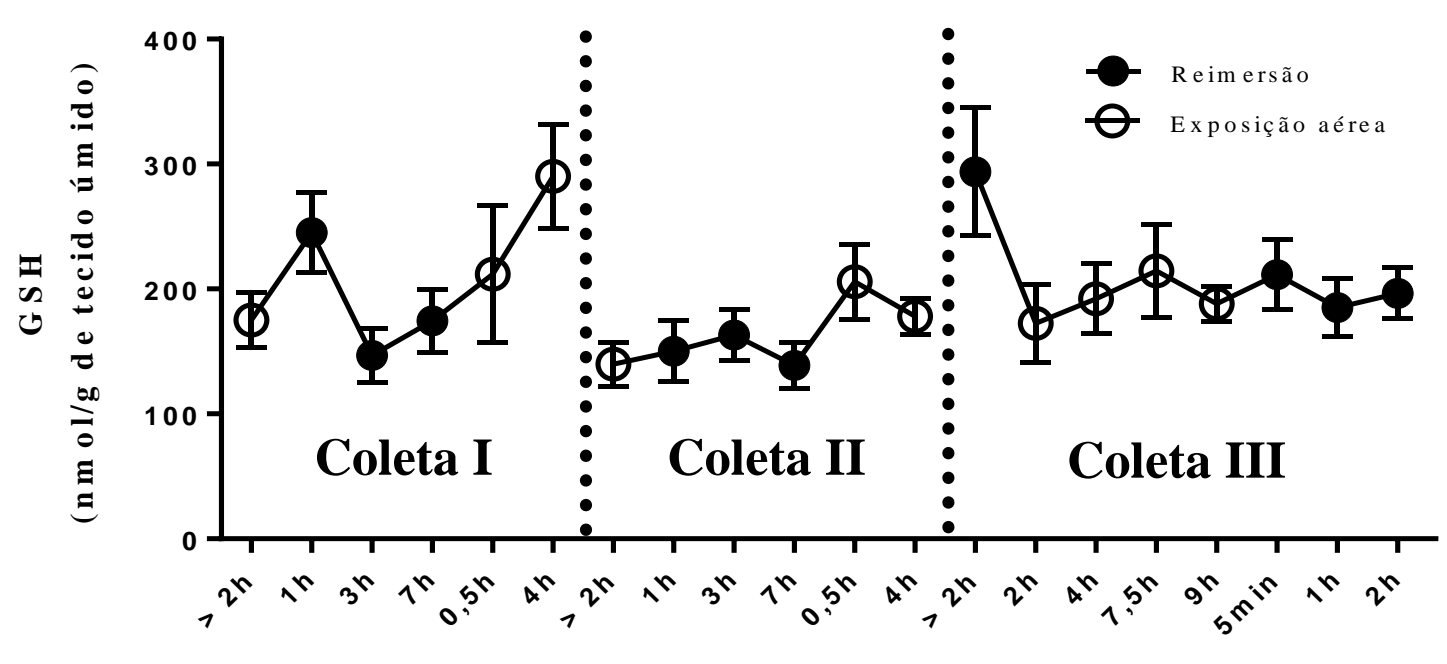

Tem po de exposição( $m$ in ou horas)

Figura 9. Níveis de glutationa (GSH) nos mexilhões medidos nas três coletas durante a reimersão e exposição aérea. Dados dos níveis de GSH da coleta I à esquerda, coleta II no centro, e coleta III à direita. Dados representados com média e erro padrão da média. $\mathrm{N}=(6-9)$ animais por grupo experimental.

Não houve diferenças entre os grupos nos níveis de GSSG na coleta I, II e III $(\mathrm{P}>0,05)$, ver figura:

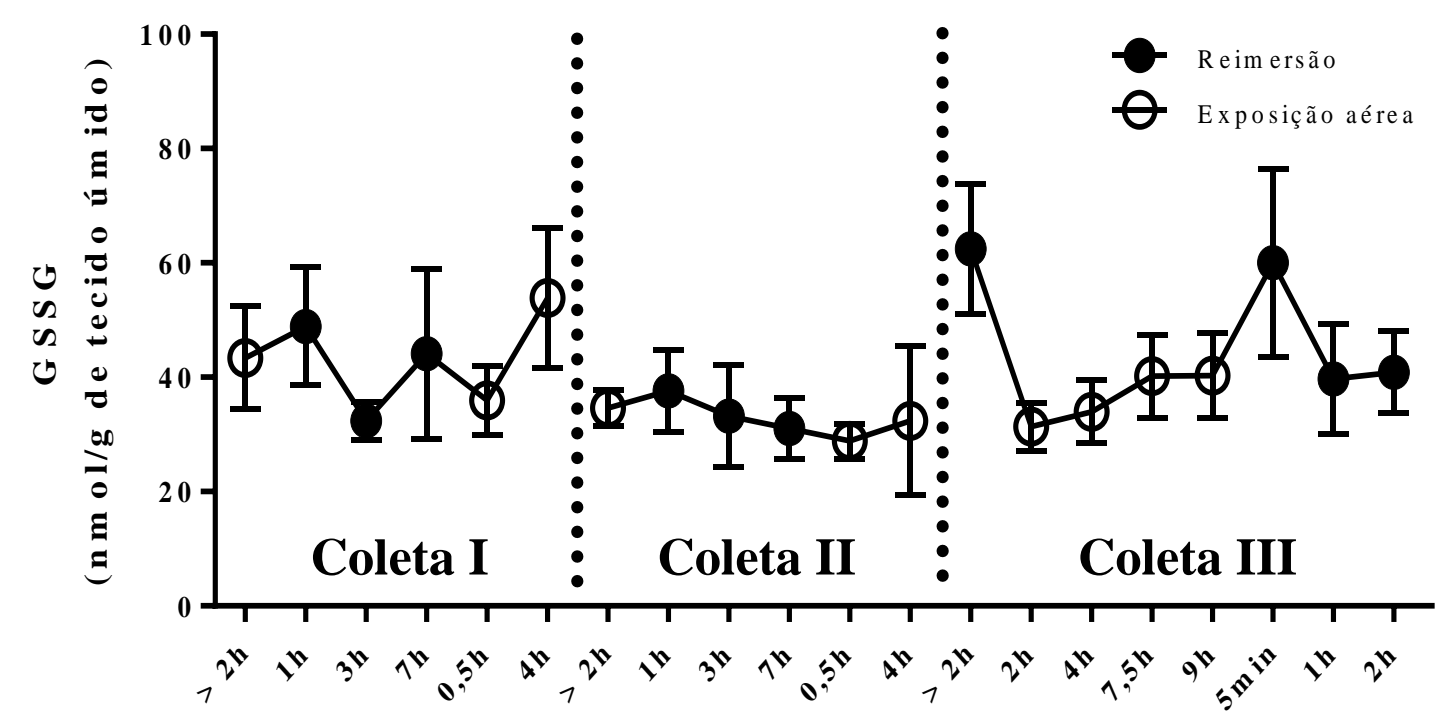

Tempo de exposição ( $m$ in ou horas)

Figura 10. Níveis de GSSG nos mexilhões medidos nas três coletas durante a reimersão e exposição aérea. Dados dos níveis de GSSG da coleta I à esquerda, coleta 
II no centro, coleta III à direita. Dados representados com média e erro padrão da média. $\mathrm{N}=(6-9)$ animais por grupo experimental.

Não houve diferenças entre os grupos na razão GSSG/Eq-GSH nas coletas I, II e III $(\mathrm{P}>0,05)$, ver figura:

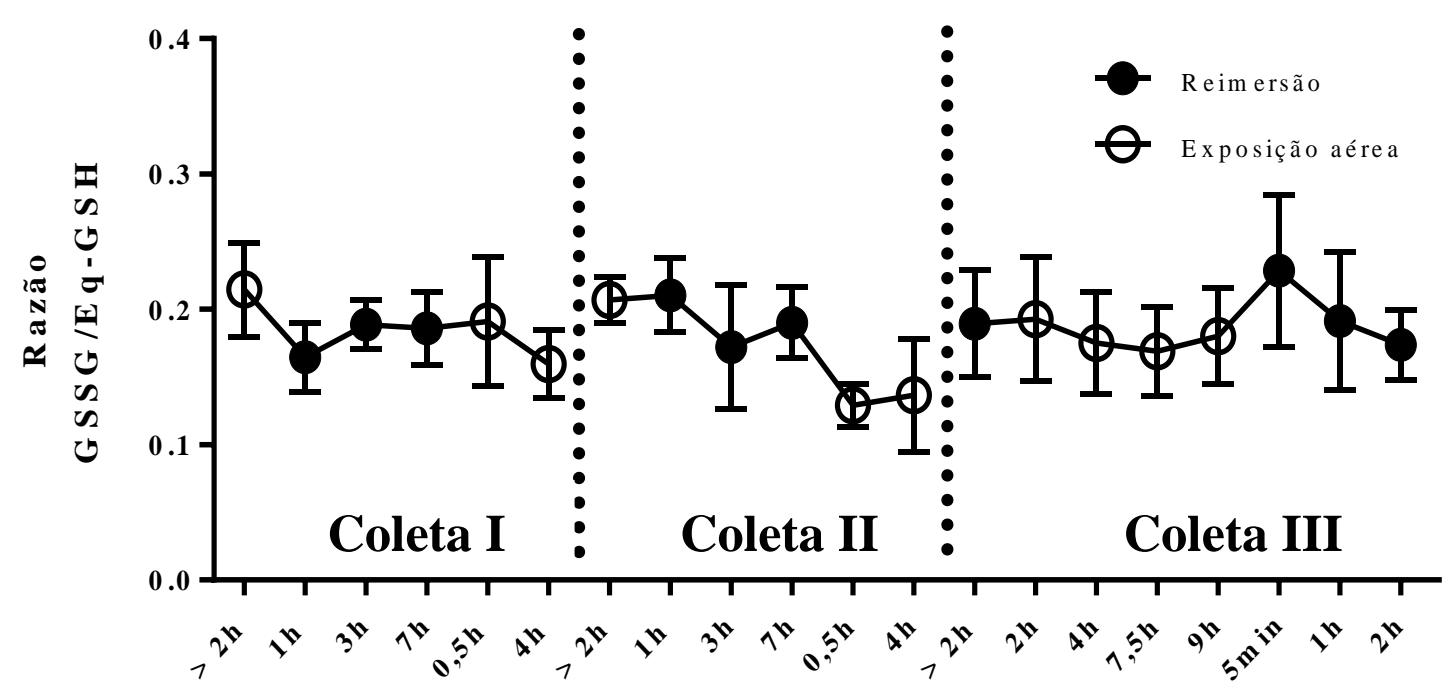

Tem po de exposição ( $m$ in ou horas)

Figura 11. Níveis de GSSG/Eq-GSH nos mexilhões medidos nas três coletas durante a reimersão e exposição aérea. Dados representados com média e erro padrão da média. $\mathrm{N}=(6-9)$ animais por grupo experimental. Dados da razão GSSG/Eq-GSH da coleta I à esquerda, coleta II no centro, coleta III à direita.

Os parâmetros de GSH (níveis médios) dos mexilhões reimersos foram comparados com outros invertebrados marinhos, com o molusco terrestre (Helix aspersa) e outras espécies que são estudadas em relação à privação de $\mathrm{O}_{2}$ (tabela 1). Estes valores médios foram tomados a partir dos animais controle sem 'nenhum' tipo de situação imposta, na mesma unidade de concentração (nmol/grama de tecido úmido). Quando os resultados eram padronizados por miligrama de proteína, eu procurei o valor dos níveis de proteína medidos (quando disponível) e passei para a mesma unidade comum entre os animais, como no caso de Doyote et al., (1997). Em outros estudos, isto não foi possível, pois os autores não informavam os níveis de proteína (Hartwig et al., 2009) ou o resultado era dado em nmol por grama de tecido seco (Power e Sheehan, 1996). Em determinadas espécies não foi possível encontrar todos os parâmetros, pois nem todos medem GSSG, e às vezes há valores de 
determinados parâmetros em trabalhos diferentes para a mesma espécie. Por exemplo, no mexilhão Mytillus edulis o dado dos níveis de Eq-GSH na tabela são de Canesi e Viarengo (1997), e GSH por Power e Sheehan (1996), a seguir tabela 1:

Tabela1. Comparação dos parâmetros de Eq-GSH, GSH, GSSG (nmol/g tecido) e razão GSSG/Eq-GSH em invertebrados.

\begin{tabular}{|c|c|c|c|c|c|c|}
\hline Família e Espécie & Tecido & Eq-GSH & GSH & GSSG & $\begin{array}{c}\text { Razão } \\
\text { GSSG/Eq- } \\
\text { GSH }\end{array}$ & Referência \\
\hline $\begin{array}{l}\text { Mytilidae, mexilhão } \\
\text { Mytilaster solisianus }\end{array}$ & Corpo inteiro & $169-356$ & $\begin{array}{c}138- \\
293\end{array}$ & $28-62$ & $0,16-0,21$ & Trabalho atual \\
\hline $\begin{array}{l}\text { Mytilidae, mexilhão } \\
\text { Mytilus californianus }\end{array}$ & Hepatopâncreas & 1000 & - & - & - & $\begin{array}{l}\text { Mitchelmorea et } \\
\text { al., } 2003\end{array}$ \\
\hline $\begin{array}{l}\text { Mytilidae, mexilhão } \\
\text { Mytilus edulis }\end{array}$ & Hepatopâncreas & 192 & $\begin{array}{c}90-450 \\
\mathrm{nmol} / \mathrm{g} \\
\text { de peso } \\
\text { seco } \\
100- \\
350 \\
\mathrm{nmol} / \mathrm{g} \\
\text { de peso } \\
\text { seco }\end{array}$ & - & - & $\begin{array}{c}\text { Eq-GSH (Canesi } \\
\text { e Viarengo) } \\
(1997) \\
\text { GSH (Power e } \\
\text { Sheehan (1996) }\end{array}$ \\
\hline $\begin{array}{c}\text { Mytilidae, mexilhão } \\
\text { Mytilus } \\
\text { galloprivincialis }\end{array}$ & $\begin{array}{c}\text { Hepatopâncreas } \\
\text { Brânquias }\end{array}$ & $\begin{array}{l}579-1276 \\
161-290\end{array}$ & - & $\begin{array}{l}- \\
-\end{array}$ & $\begin{array}{l}- \\
-\end{array}$ & $\begin{array}{c}\text { Regoli e } \\
\text { Principato, } 1995\end{array}$ \\
\hline $\begin{array}{l}\text { Mytilidae, mexilhão } \\
\text { Perna perna }\end{array}$ & Hepatopâncreas & 1300 & 1291 & 8,92 & 0,006 & $\begin{array}{l}\text { Dafre et al., } \\
2004 \\
\text { Franco et al., } \\
2006\end{array}$ \\
\hline $\begin{array}{l}\text { Arcticidae, marisco } \\
\text { Arctica islandica }\end{array}$ & Brânquias & $\begin{array}{c}304-754 \\
1027- \\
1798\end{array}$ & $\begin{array}{c}214- \\
402 \\
420-730\end{array}$ & $49-179$ & $0,17-0,43$ & $\begin{array}{l}\text { Abele et al., } \\
2008\end{array}$ \\
\hline $\begin{array}{l}\text { Unionidea, mexilhão } \\
\text { Unio tumidus }\end{array}$ & $\begin{array}{c}\text { Hepatopâncreas } \\
\text { Brânquias }\end{array}$ & $\begin{array}{l}3040 \\
3200\end{array}$ & $\begin{array}{l}1920 \\
2480\end{array}$ & $\begin{array}{l}1056 \\
992\end{array}$ & $\begin{array}{l}0,34 \\
0,31\end{array}$ & $\begin{array}{l}\text { Doyote et al., } \\
1997\end{array}$ \\
\hline $\begin{array}{l}\text { Mytilidae, mexilhão } \\
\text { Geukensia demissa }\end{array}$ & Hepatopâncreas & $750-1700$ & - & - & - & $\begin{array}{c}\text { Khan e } \\
\text { Ringwood, } 2016\end{array}$ \\
\hline $\begin{array}{c}\text { Littorinidae, caramujo } \\
\text { marinho Littorina } \\
\text { littoria }\end{array}$ & Hepatopâncreas & 320 & 187 & 91 & 0,28 & $\begin{array}{l}\text { Pannunzio e } \\
\text { Storey, } 1998\end{array}$ \\
\hline $\begin{array}{l}\text { Caramujo marinho } \\
\text { Nacella pollaris }\end{array}$ & Hepatopâncreas & - & 100 & - & - & $\begin{array}{l}\text { Ansaldo et al., } \\
2007\end{array}$ \\
\hline $\begin{array}{c}\text { Ostreidae, ostra } \\
\text { Crassostrea gigeas }\end{array}$ & Brânquias & $600-1000$ & - & - & - & $\begin{array}{c}\text { Trevisan et al., } \\
2012\end{array}$ \\
\hline $\begin{array}{c}\text { Ostreidae, ostra } \\
\text { Crassostrea virginica }\end{array}$ & Hepatopâncreas & $\begin{array}{l}1000- \\
2600\end{array}$ & - & - & - & $\begin{array}{c}\text { Khan e } \\
\text { Ringwood, } 2016\end{array}$ \\
\hline $\begin{array}{l}\text { Helicidae, caramujo } \\
\text { terrestre }\end{array}$ & Hepatopâncreas & 1620 & 1400 & 160 & 0,098 & \multirow[t]{2}{*}{$\begin{array}{l}\text { Welker et al., } \\
2016\end{array}$} \\
\hline Helix aspersa & Músculo do pé & 740 & 660 & 70 & 0,094 & \\
\hline $\begin{array}{l}\text { Rhabditidae } \\
\text { Caenorhabditis } \\
\text { elegans }\end{array}$ & Corpo inteiro & $\begin{array}{c}15 \\
\text { nmol/mg } \\
\text { proteína }\end{array}$ & $\begin{array}{c}13 \\
\text { nmol/mg } \\
\text { proteína }\end{array}$ & $\begin{array}{c}2 \\
\text { nmol/mg } \\
\text { proteina }\end{array}$ & 0,13 & $\begin{array}{l}\text { Hartwig et al., } \\
2009\end{array}$ \\
\hline
\end{tabular}


Na tabela, alguns animais apresentam faixas nos parâmetros de GSH porque os níveis era diferentes em diferentes momentos no tempo (incluindo época). Por exemplo, na espécie Mytilaster solisianus que eu estudei, os níveis de Eq-GSH no corpo inteiro na fase de reimersão varia entre $169-356 \mathrm{nmol} / \mathrm{g}$ de tecido úmido em diferentes épocas. No trabalho de Abele et al., (2008), o mexilhão Arctica islandica no tecido branquial (órgão responsável pelas trocas gasosas) tem níveis de Eq-GSH que variam entre $1027-1798 \mathrm{nmol} / \mathrm{g}$ de tecido úmido, pois os animais foram coletados de locais diferentes. O gastrópode marinho Littorina littorea possui em torno de 320 nmol/g de tecido de Eq-GSH no hepatopâncreas (órgão com função central no metabolismo energético, e no metabolismo de xenobióticos) (Pannunzio e Storey, 1998), o mexilhão Mytillus edulis possui no mesmo órgão $608 \mathrm{nmol} / \mathrm{g}$ de tecido de Eq-GSH, as brânquias possuem menos Eq-GSH, com 192 nmol/ g de tecido (Canesi e Viarengo, 1997). No gastrópode terrestre Helix aspersa tem no hepatopâncreas em torno de $1620 \mathrm{nmol} / \mathrm{g}$ de tecido de Eq-GSH (Welker et al., 2016), ver tabela 1.

Interessantemente, assim como os níveis de Eq-GSH, os níveis de GSSG variam muito entre os moluscos, entre $28-62 \mathrm{nmol} / \mathrm{g}$ de tecido no corpo inteiro de Mytilaster solisianus, sendo que, no mexilhão Unio tumidus, o valor encontrado para GSSG no hepatopâncreas foi de $1056 \mathrm{nmol} / \mathrm{g}$ de tecido úmido (Doyote et al., 1997), e entre 303-534 nmol/g de tecido no tecido branquial de Arctica islandica, o que nesta espécie, a idade é um fator que influência os níveis de GSSG (Abele et al., 2008). Isto pode influenciar a razão GGSG/Eq-GSH (e importante marcador de estresse oxidativo, Marí et al., 2009), sendo que alguns animais (Arctica islandica) possuem inacreditáveis 70\% de GSSG (Abele et al., 2008). Este valor de porcentagem foi obtido através da razão GSSG/Eq-GSH, e multiplicado por 100, mas a partir do que se sabe, o molusco Arctica islandica é tido no mundo animal como a segunda espécie mais longeva (Philip e Abele, 2008). No gastrópode marinho Littorina littoria, há 28 e 12\% de GSSG no hepatopâncreas e brânquias, respectivamente (Pannunzio e Storey, 1998).

Em organismos tradicionais de pesquisa, alguns autores afirmam de maneira geral que os níveis intracelulares de GSH seriam em torno de 100 vezes mais do que os níveis de GSSG em condições fisiológicas (Meister e Anderson, 1983; Griffith, 1999). Dados de Griffith (1980) em tecidos camundongos, mostraram que o fígado 
tem em torno de 3,62\% de GSSG, enquanto que o rim tem 3,55\% (a partir do mesmo método de análise do trabalho presente). O invertebrado nematódeo Caenorhabditis elegans, por exemplo, possui 13\% de GSSG, em análise de animais de corpo inteiro (Hartwig et al., 2009) (ver tabela 1). Deste modo, os níveis de GSH e GSSG variam entre espécies e órgãos analisados.

\subsection{ESTUDOS DE CORRELAÇÃO}

Como cada animal teve o seu peso e tamanho registrados antes das análises ou previamente a elas (tamanho), pôde-se fazer o perfil de correlação dos parâmetros de GSH medidos para cada amostra animal, incluindo também peso (mg) e comprimento $(\mathrm{cm})$.

Houve correlação entre os níveis de GSH e Eq-GSH, ver figura:

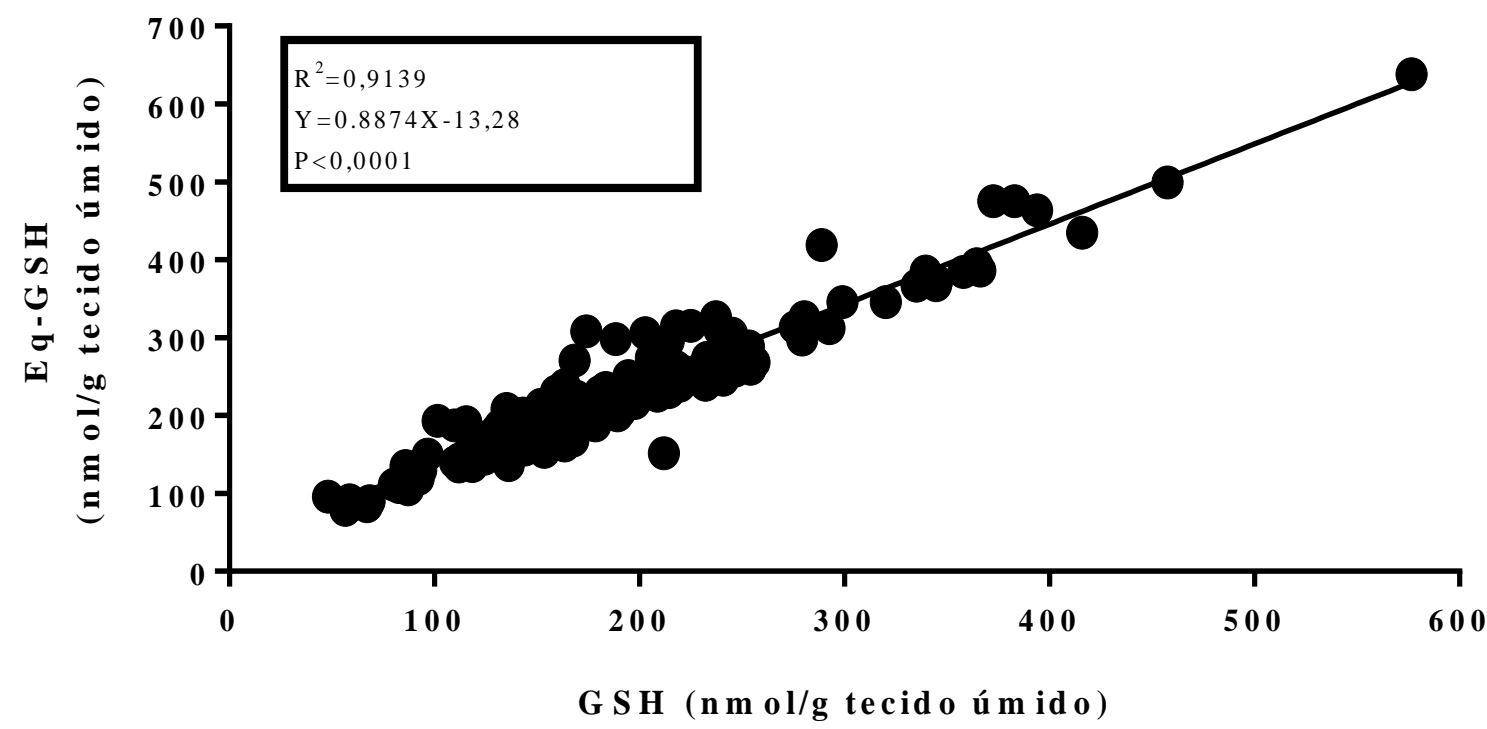

Figura 12. Correlação entre os níveis de GSH e Eq-GSH em todos os mexilhões analisados. $\mathrm{N}=146$ animais.

Houve correlação entre os níveis de GSSG e Eq-GSH, ver figura: 


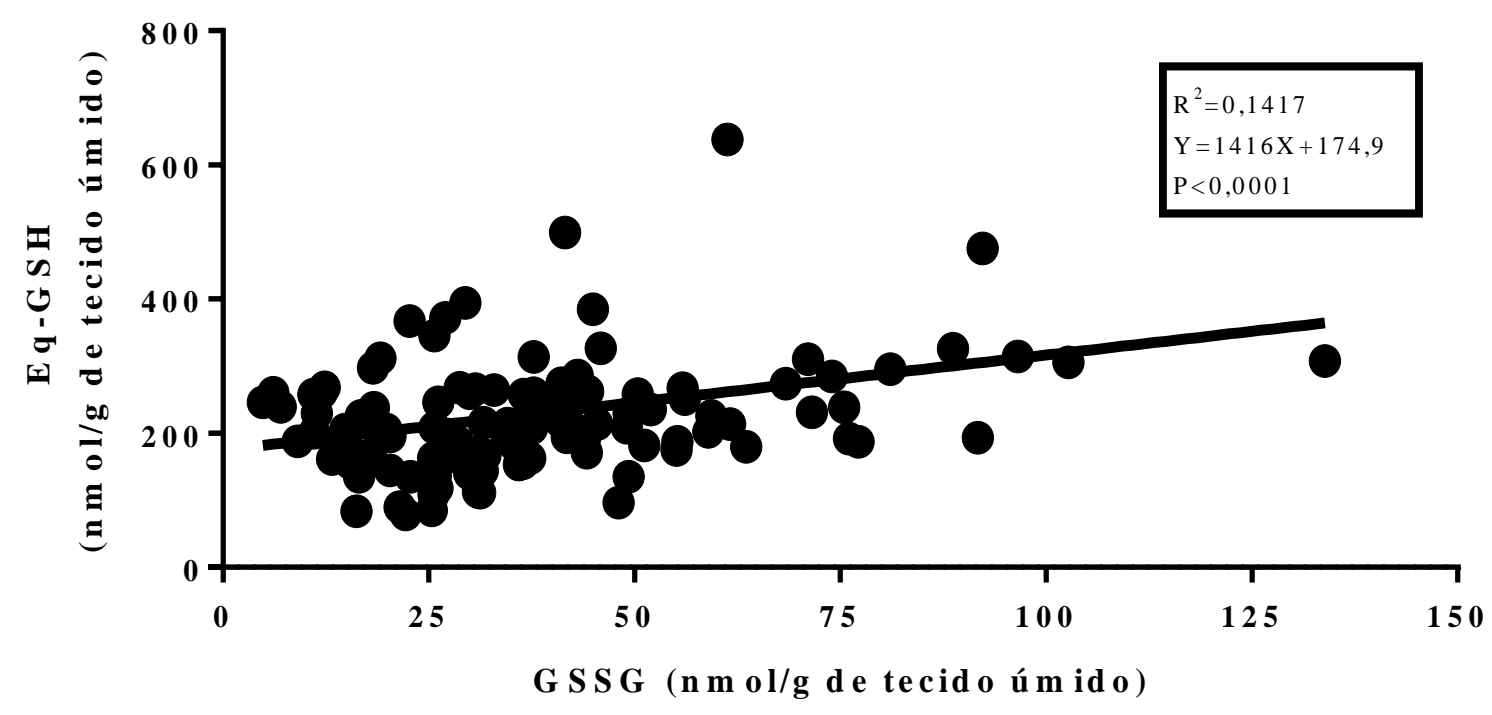

Figura 13. Correlação entre os níveis de GSSG e Eq-GSH em todos os mexilhões analisados. $\mathrm{N}=146$ animais.

Houve correlação entre os níveis de GSH e a razão GSSG/Eq-GSH, ver figura:

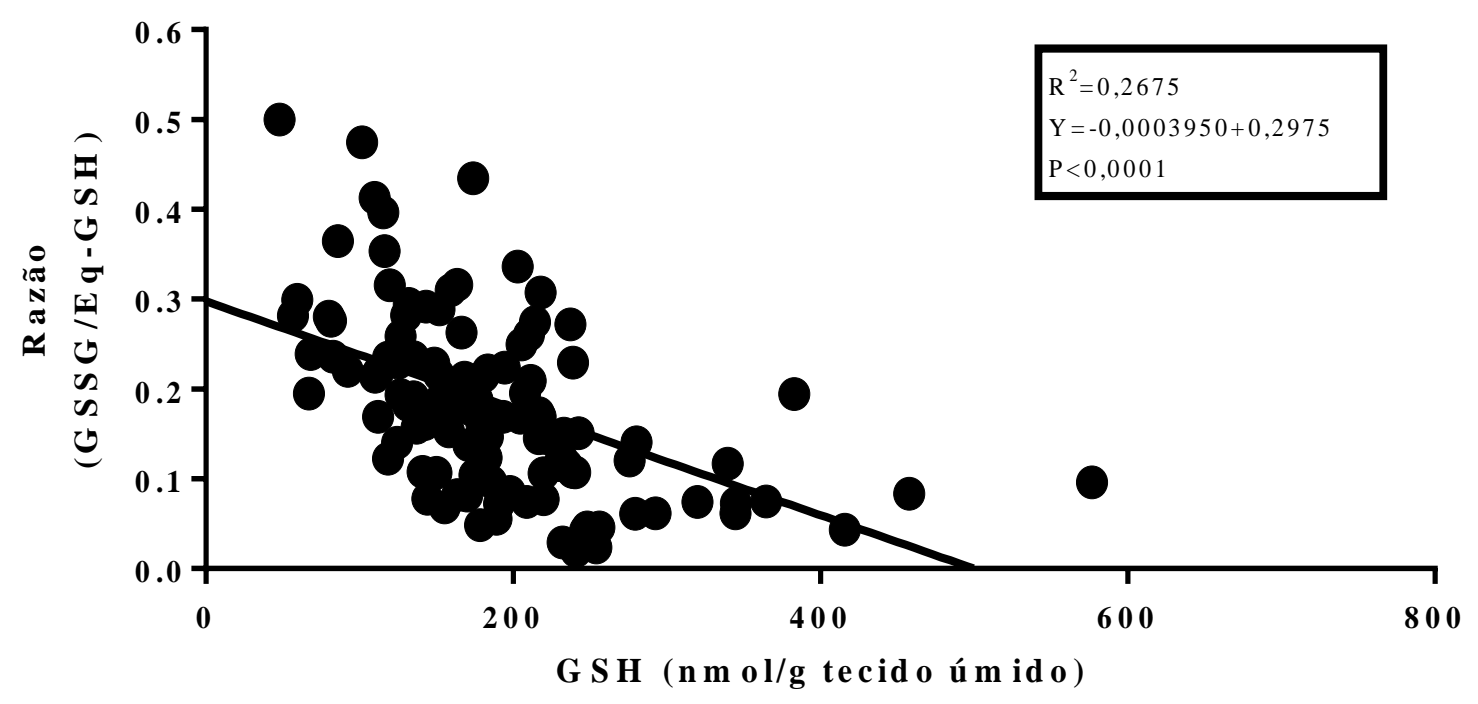

Figura 14. Correlação entre os níveis de GSH e a razão GSSG/Eq-GSH em todos os mexilhões analisados. $\mathrm{N}=146$ animais.

Houve correlação entre os níveis de GSSG e a razão GSSG/Eq-GSH, ver figura: 


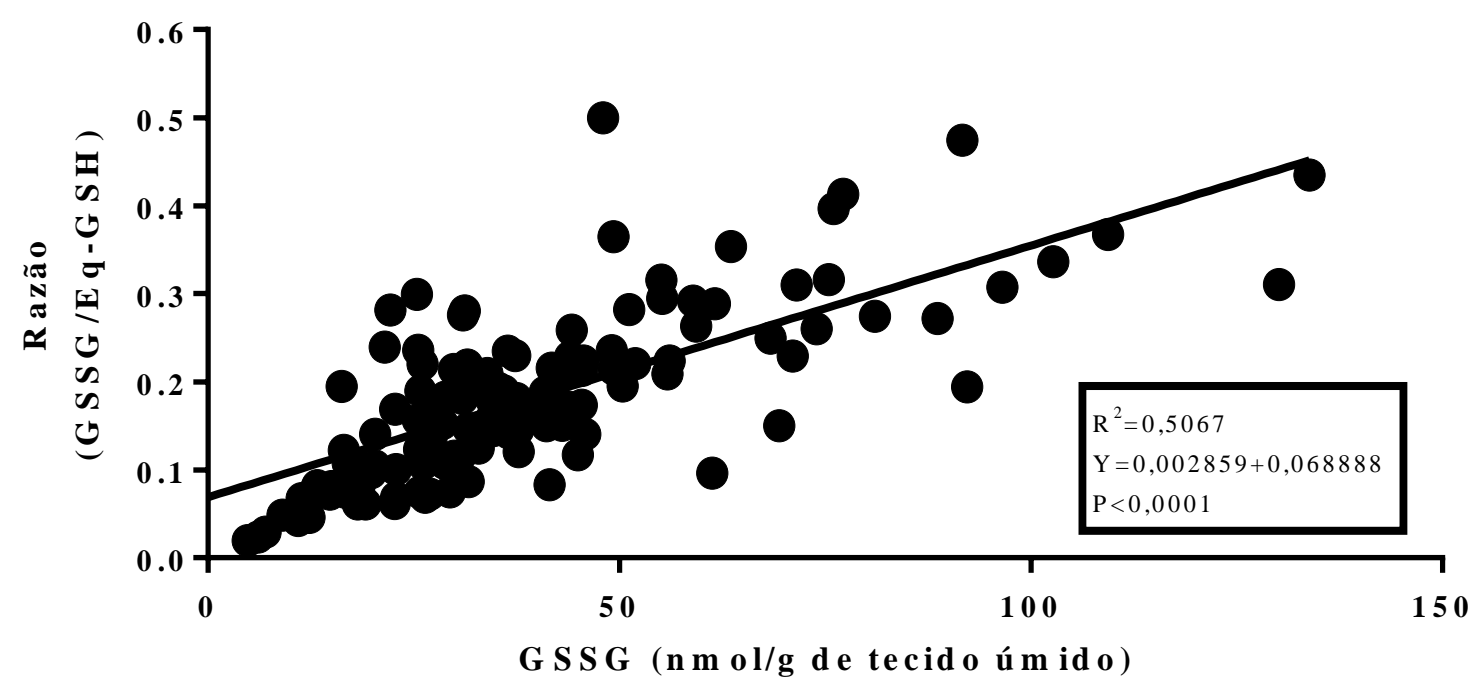

Figura 15. Correlação entre os níveis de GSSG e a razão GSSG/Eq-GSH em todos os mexilhões analisados. $\mathrm{N}=146$ animais.

Houve correlação entre tamanho e os níveis de Eq-GSH, ver figura:

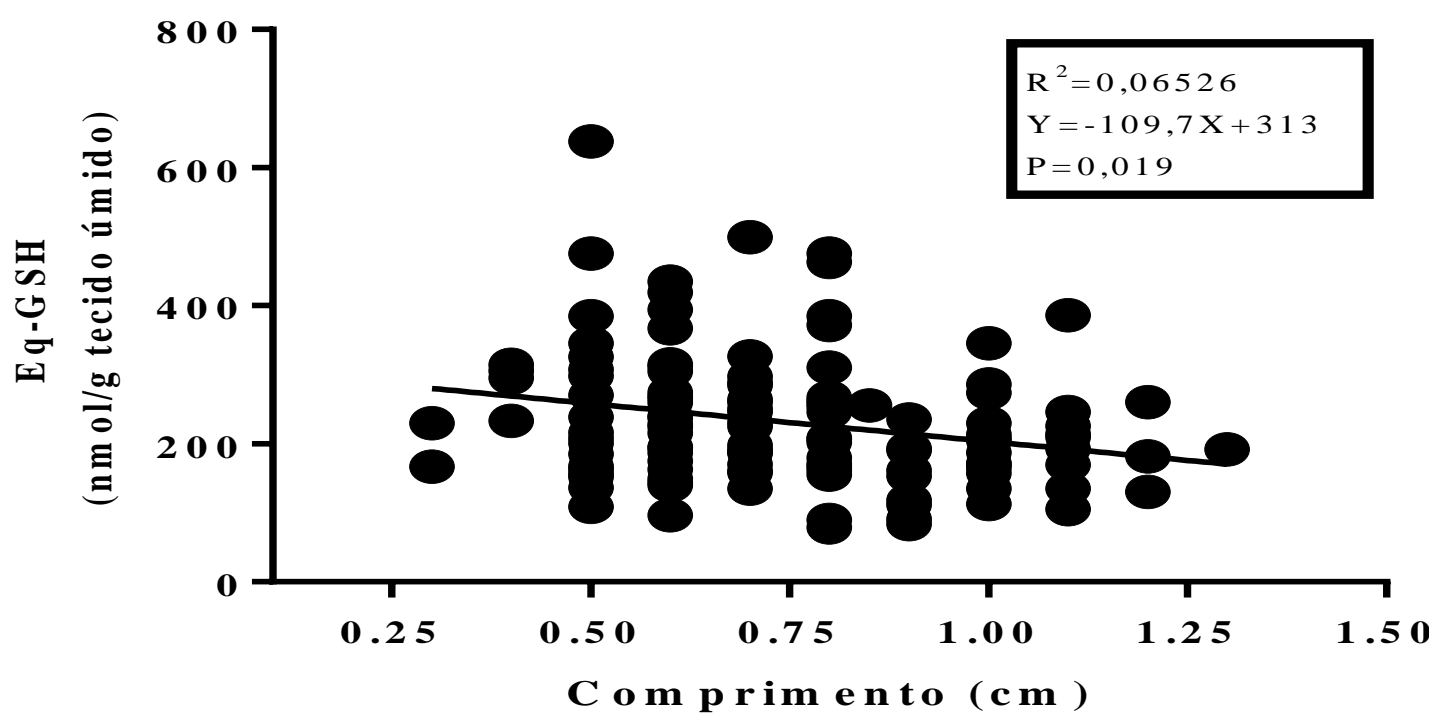

Figura 16. Correlação entre os níveis de Eq-GSH e comprimento em todos os mexilhões analisados. $\mathrm{N}=146$ animais.

Houve correlação entre tamanho e os níveis de GSH, ver figura: 


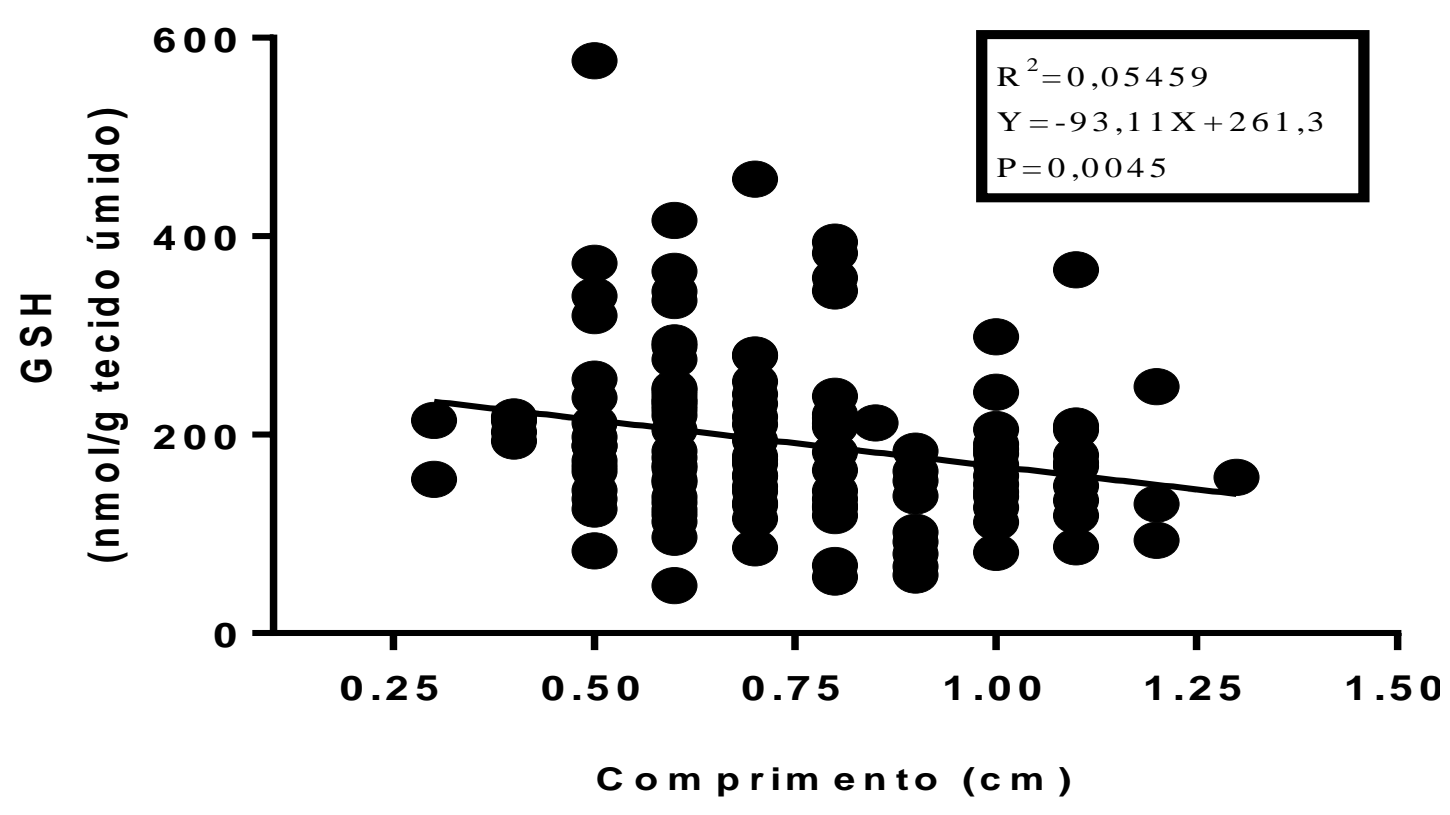

Figura 17. Correlação entre os níveis de GSH e comprimento em todos os mexilhões analisados. $\mathrm{N}=146$ animais.

Não houve correlação entre tamanho e os níveis de GSSG, ver figura:

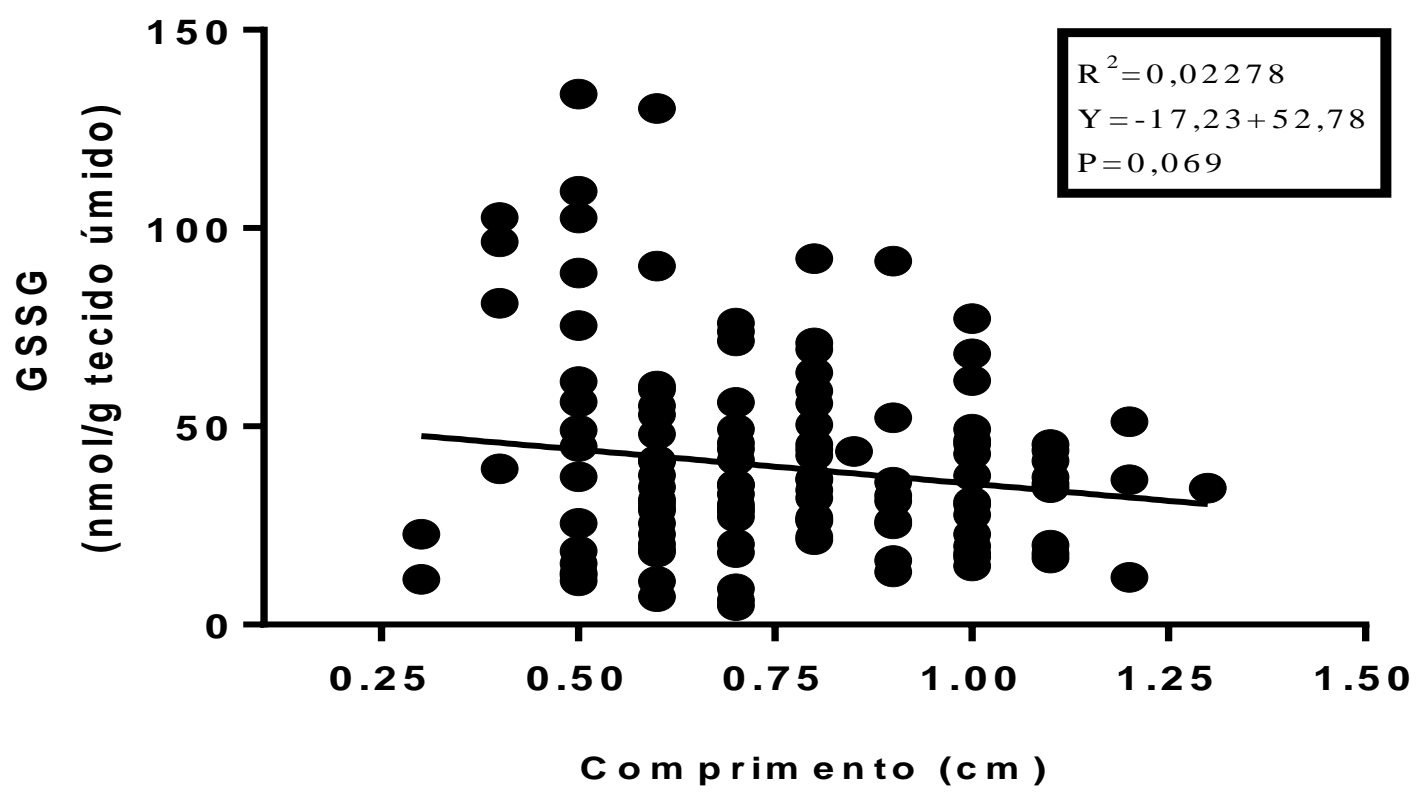

Figura 18. Correlação entre os níveis de GSSG e comprimento em todos os mexilhões analisados. $\mathrm{N}=146$ animais. 
Não houve correlação entre tamanho e a razão GSSG/Eq-GSH, ver figura:

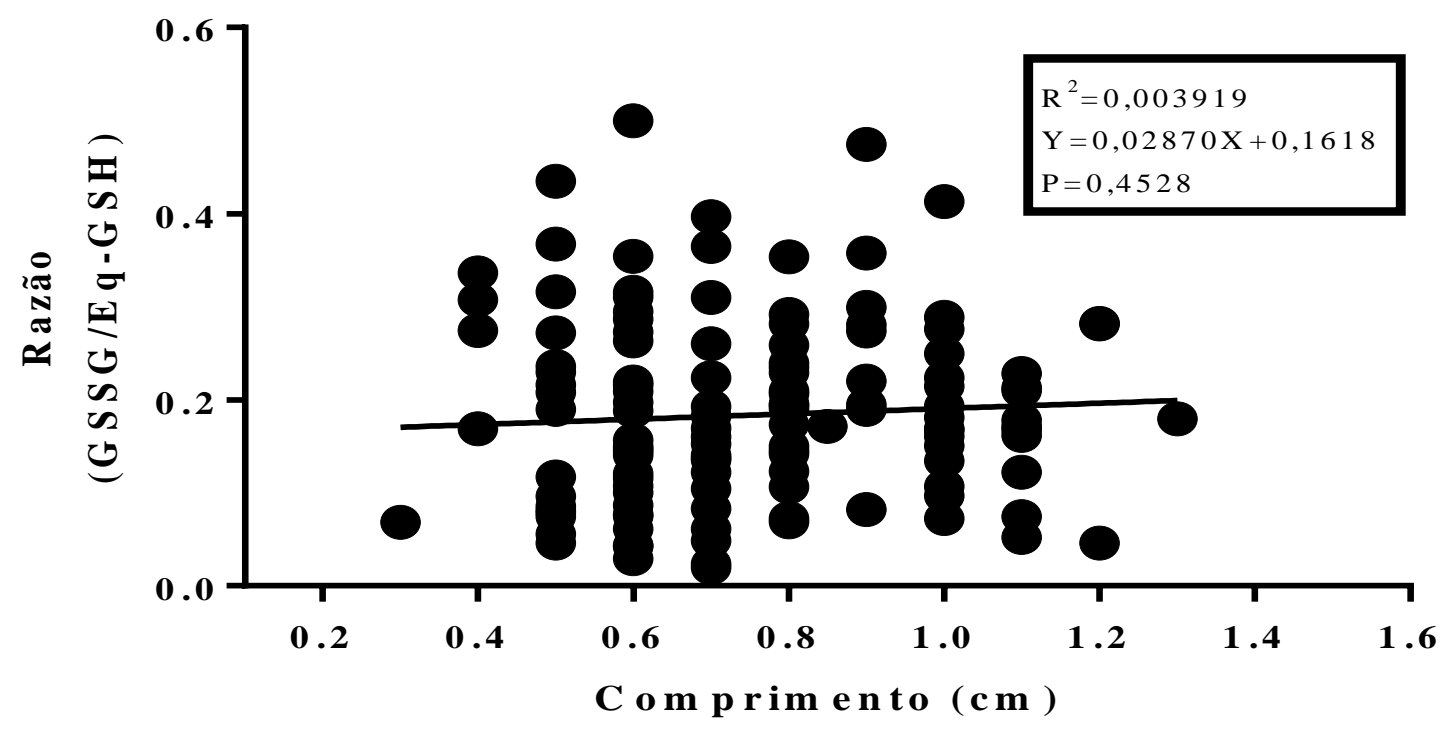

Figura 19. Correlação entre a razão GSSG/Eq-GSH e comprimento em todos os mexilhões analisados. $\mathrm{N}=146$ animais.

Houve correlação entre peso e os níveis de Eq-GSH, ver figura:

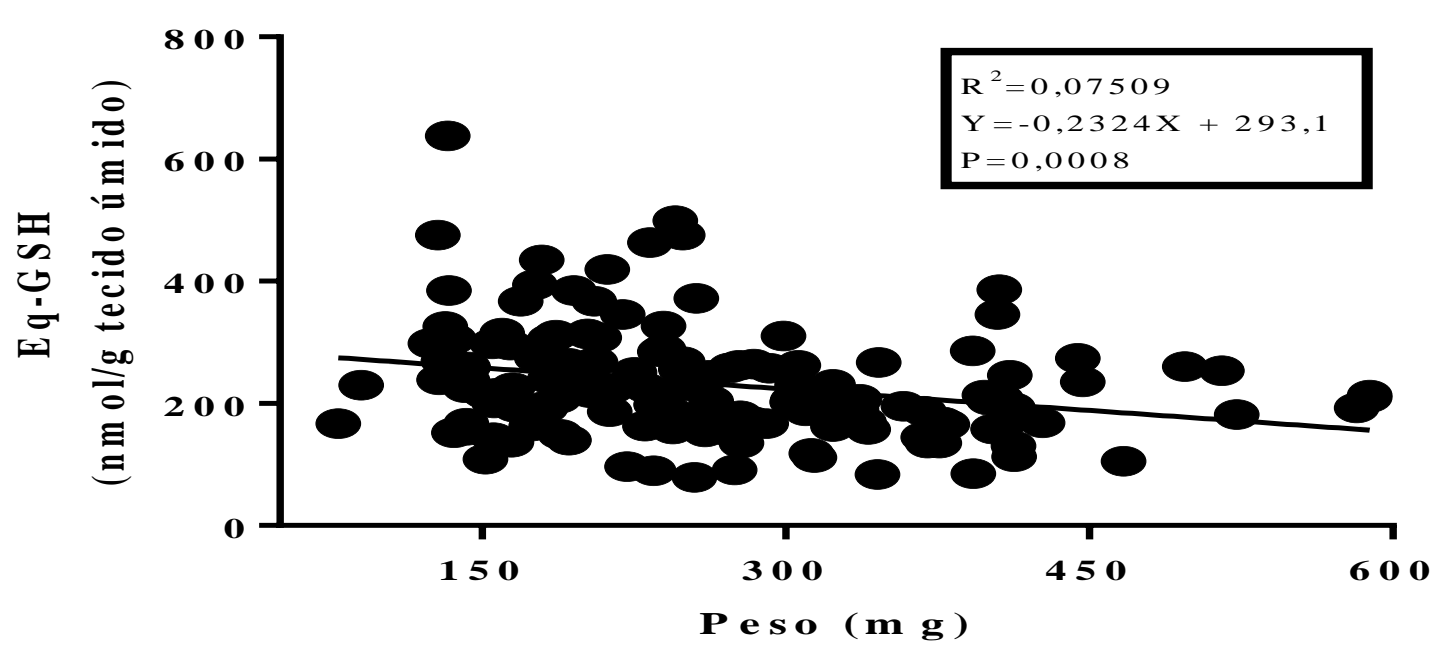

Figura 20. Correlação entre os níveis de Eq-GSH e peso em todos os mexilhões analisados. $\mathrm{N}=146$ animais.

Houve correlação entre peso e os níveis de GSH, ver figura: 


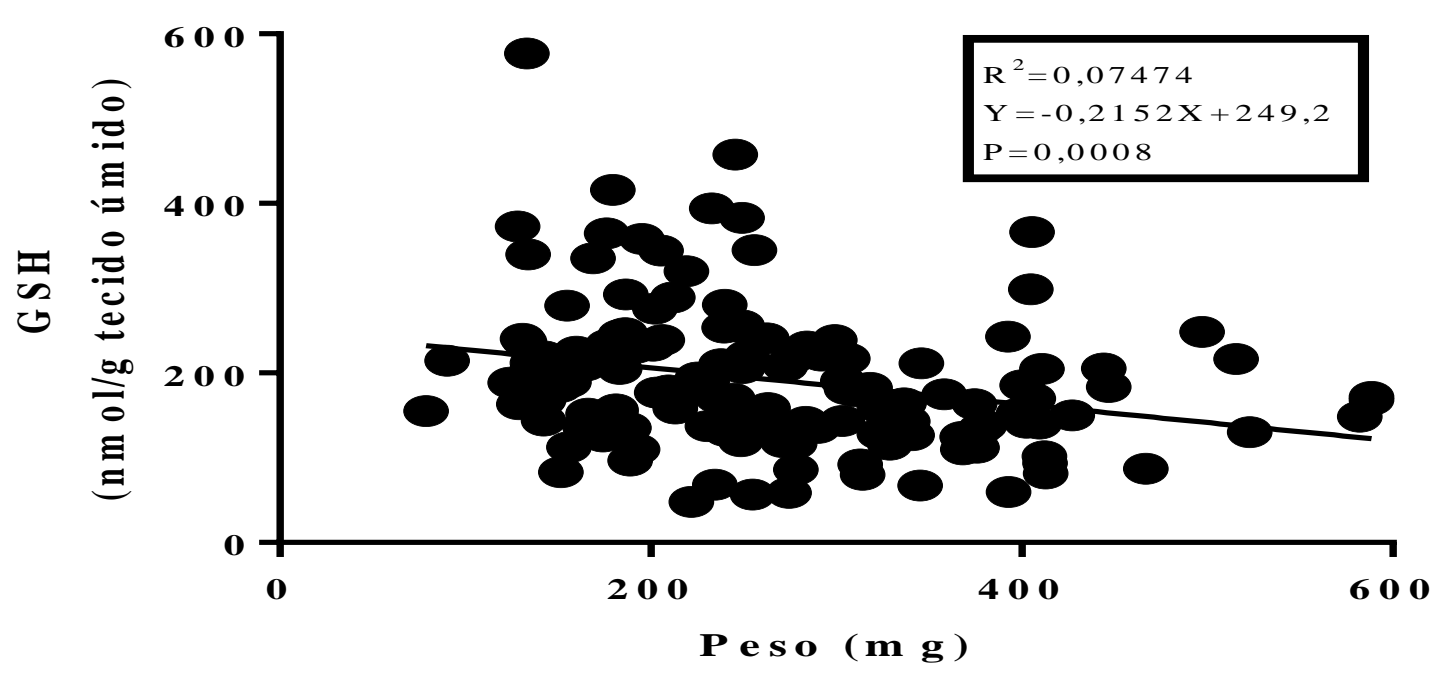

Figura 21. Correlação entre os níveis de GSH e peso em todos os mexilhões analisados. $\mathrm{N}=146$ animais.

Não houve correlação entre peso e os níveis de GSSG, ver figura:

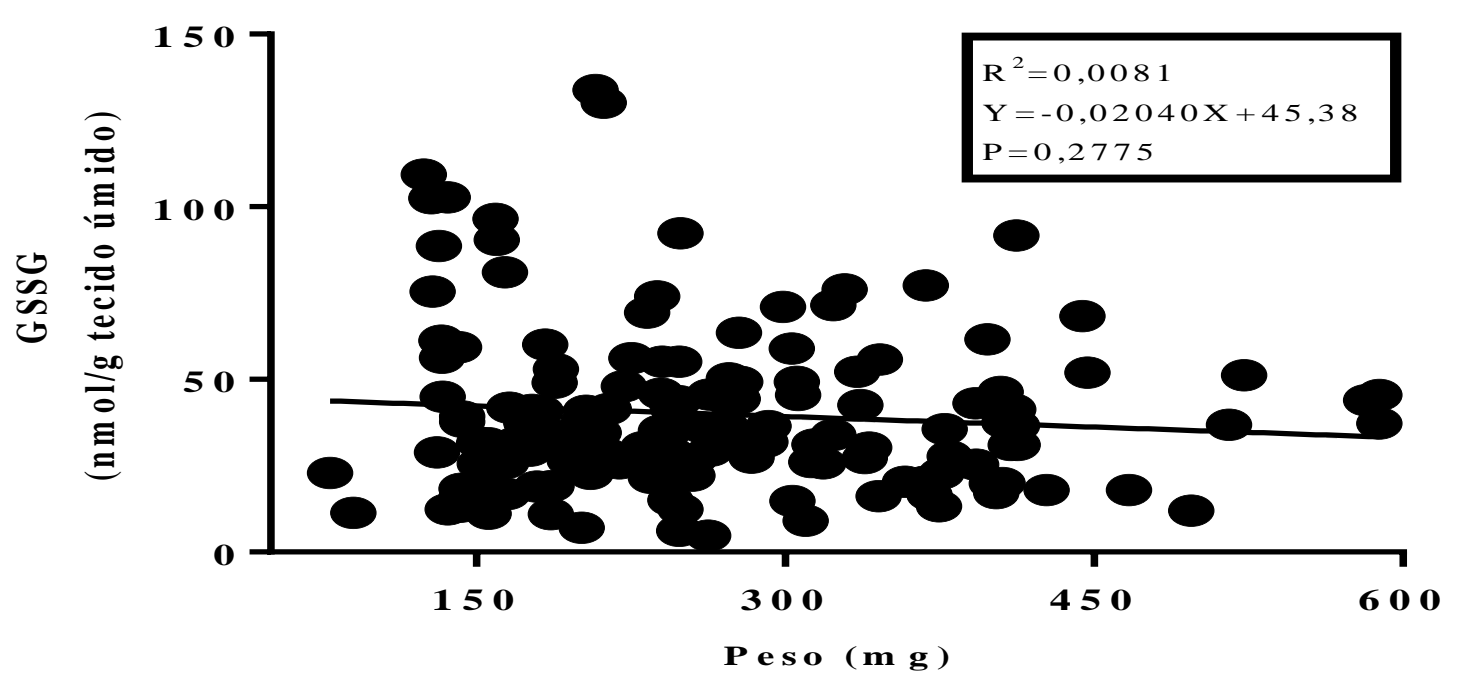

Figura 22. Correlação entre os níveis de GSSG e peso em todos os mexilhões analisados. $\mathrm{N}=146$ animais.

Não houve correlação entre peso e a razão GSSG/Eq-GSH, ver figura: 


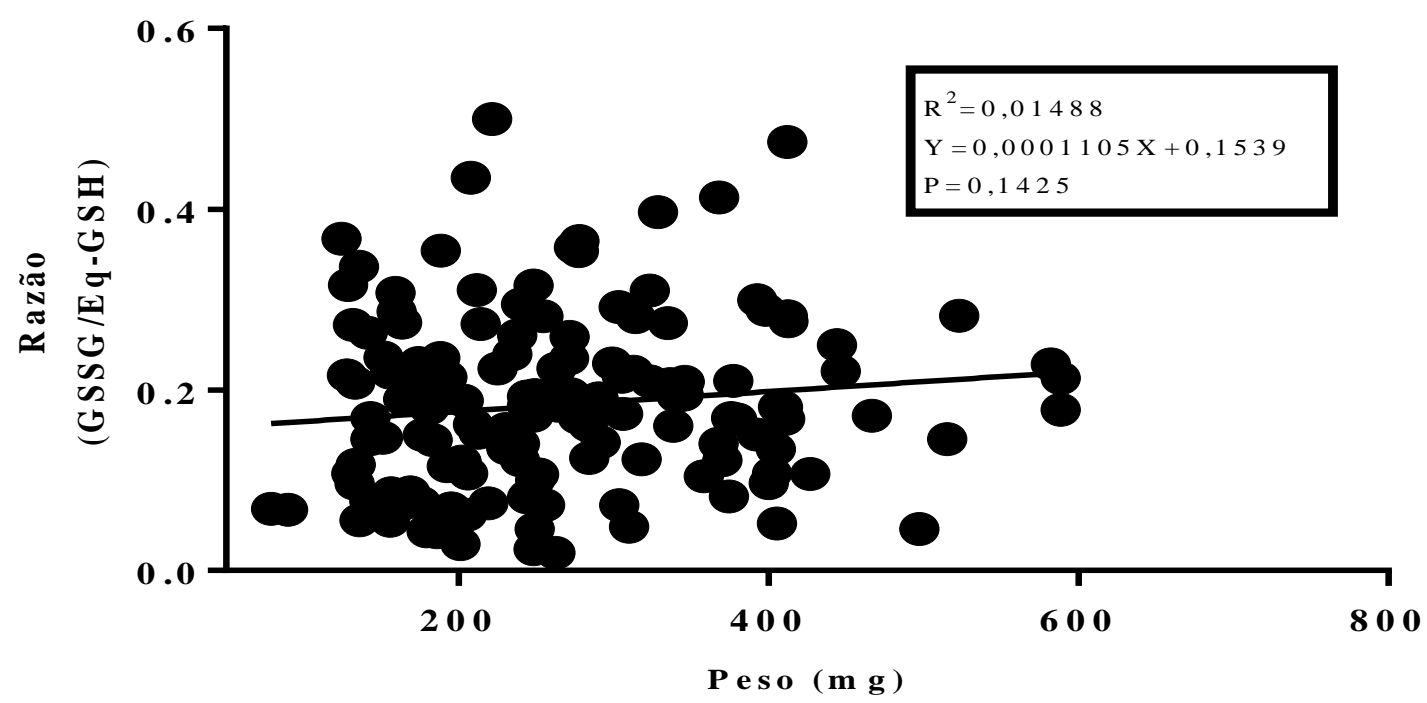

Figura 23. Correlação entre a razão GSSG/Eq-GSH e peso em todos os mexilhões analisados. $\mathrm{N}=146$ animais.

\section{DISCUSSÃO}

Neste trabalho, foram monitorados os parâmetros de GSH durante ciclos naturais de marés em mexilhões da espécie Mytilaster solisianus, com uma robusta e representativa população de 146 espécimes de animais. Na mesma rocha de coleta, fez-se um perfil de possíveis mudanças relacionadas ao status redox em análise de corpo inteiro envolvendo GSH, em um ambiente no qual os fatores abióticos mudam e podem flutuar periodicamente durante a descida e subida das marés, com menor ou maior tempo de exposição aérea, com a ocorrência ou não de mudanças de temperatura ambiente. E mesmo assim, nestas condições de extremo fisiológico, os mexilhões mostraram manter a homeostase redox, devido à ausência do aumento dos indicadores de estresse oxidativo e desequilibtio redox, analisados por GSSG e razão GSSG/Eq-GSH. Esta resistência foi mais eloquente na coleta de número III, na qual os animais experimentaram uma alta temperatura ambiente de $28^{\circ} \mathrm{C}$. As respostas fisiológicas de mexilhões à exposição aérea se encontram na seção de discussão geral e conclusões.

Em relação às correlações, houve um padrão de queda entre os níveis de EqGSH e GSH em relação ao peso e tamanho (figuras 16, 17, e 20 e 21). Não é possível dizer qual é a idade exata dos mexilhões analisados neste trabalho, mas a ideia 
corrente é que quanto maiores forem os mexilhões e outros moluscos, mais velhos são os animais (Anwar et al., 1990; Abele et al., 2008). Alguns trabalhos mostram que os níveis Eq-GSH diminuem com o aumento da idade no mexilhão Mytilus edulis, assim como as enzimas envolvidas no seu metabolismo, como glutamil-cisteína ligase (etapa limitante para a biossíntese de GSH) e GST, com ocorrência de baixos níveis de atividade enzimática, nos dois tecidos analisados, brânquias e hepatopâncreas (Canesi e Viarengo, 1997). Porém, estes autores observaram que GR, que renova GSH a partir de GSSG e NADPH, tem seus níveis de atividade aumentados nas brânquias (tecido com níveis maiores de GSH do que o hepatopâncreas nesta espécie), compensando a baixa da síntese de GSH (Canesi e Viarengo, 1997). A queda dos níveis de GSH com o decorrer da idade também é observada em Arctica islandica (Abele et al., 2008).

Há poucos trabalhos que estudaram a resposta antioxidante de animais na exposição aérea com espécies de invertebrados e todos feitos em laboratório, com raras exceções. Teixeira et al., (2013) submeteram a espécie de coral Veretillum cynomorium à exposição aérea e, em análise de corpo inteiro, observaram aumento de atividade de catalase (310\%) após duas horas de exposição aérea, em relação ao grupo de animais recém expostos ao ar (grupo zero). Houve também aumento dos níveis de atividade de GST, quanto comparado com o grupo zero. As atividades das enzimas catalase e GST retornam ao nível do grupo zero após três horas de reimersão, e sem mudanças para os níveis de atividade de SOD nestas condições (Teixeira et al., 2013). Infelizmente, fica a dúvida se estes aumentos são reais, pois os parâmetros não foram padronizados por miligrama de proteínas e os animais podem ter perdido água durante a exposição aérea. Medições por miligrama de proteínas evita este efeito de nível de hidratação de tecidos, sendo este tipo de padronização comum entre vários trabalhos (Freire et al., 2011a; Welker et al., 2016). As enzimas podem estar mais concentradas por estarem em um meio com menor teor de água.

Em carangueijos Paralomis granulosa expostos ao ar por tempos entre três e 24 horas, o estudo de Romero et al., (2007) observou mudanças nas atividades de catalase, GST e SOD em diferentes tecidos (i.e. hemolinfa, brânquias, tecido muscular e hepatopâncreas). No tecido branquial, SOD cai após três horas de exposição aérea e se mantém baixa até o fim da exposição aérea, aumenta a atividade 
após seis horas no tecido muscular, voltando os níveis de atividade ao nível do controle após 12 e 24 horas de exposição aérea. No hepatopâncreas, a enzima tem aumento de atividade após três horas de exposição aérea, ficando com o mesmo nível de atividade entre seis e 12 horas, e retorna os níveis de atividade ao nível do controle após 24 horas de exposição aérea (Romero et al., 2007). Catalase e GST também aumentam de maneira geral nos outros tecidos em resposta à exposição aérea, com exceção de GST que teve seus níveis diminuídos no tecido muscular entre três e seis horas de exposição aérea, e após 12 horas de exposição aérea retorna no nível do controle (Romero et al., 2007). Este estudo ilustra bem como diferentes tecidos respondem diferentemente e temporalmente nos níveis de mudanças de atividade enzimática em resposta à exposição aérea, e as atividades das enzimas mais aumentam do que caem. Esta é uma resposta ao estresse oxidativo durante a exposição aérea? Ainda nos carangueijos, Freire et al., (2011a) compararam a resposta antioxidante frente à exposição aérea em duas espécies pertencentes ao mesmo gênero, Calinnectes danae e Callinectes ornatus. Em resposta a três horas de exposição aérea, não houve mudança nos níveis de atividade de catalase, Se-GPx (peroxidase específica para $\mathrm{H}_{2} \mathrm{O}_{2}$ ) e GST nas brânquias anteriores e posteriores em ambas as espécies (Freire et al., 2011a). Por outro lado, em C. ornatus, houve aumento dos níveis de atividade de catalase (280\%) e Se-GPx (140\%) no tecido muscular. GST não se alterou neste tecido. Em C. danae, não houve alteração dos níveis de atividade para estas enzimas. Por outro lado, no hepatopâncreas, a atividade de catalase cai $(90 \%)$ em $C$. danae, porém, sem alterações em C. ornatus (Freire et al., 2011a). Mesmo com a baixa da atividade de catalase, as enzimas mais aumentam do que caem. Seria este mais um caso de resposta ao estresse oxidativo na exposição aérea? Apesar de serem espécies próximas, mesmo gênero, elas têm respostas diferentes à exposição aérea. No caso, estas espécies possuem distribuições diferentes na região de estuário, $C$. ornatus prefere locais do estuário com maior teor de salinidade e $C$. danae áreas com menor grau de salinidade, o que talvez explique as diferenças encontradas (Freire et al., 2011a).

Nos moluscos (bivalve) Chlamys farreri, houve um leve aumento da atividade de SOD (39\%) em hemócitos após duas horas de exposição aérea (Chen et al., 2007). No mexilhão Perna perna, houve aumento dos níveis de GST (52\%) no 
hepatopâncreas em resposta a 18 horas de exposição aérea, sem alterações dos níveis de Eq-GSH e dos níveis de atividade de SOD, catalase e GPx, e sem ocorrência de mudanças destes parâmetros nas brânquias (Almeida et al., 2005). Estes mesmos sistemas foram avaliados em outro artigo (Almeida e Bayne, 2006), e SOD teve seus níveis de atividade aumentados (26\%) após 4 horas de exposição aérea. Assim como os resultados de Almeida et al., (2005), níveis de Eq-GSH e de atividade de catalase e GPx não sofreram mudanças. Na ostra Pinctada fucata, houve queda dos níveis de RNAm de GST e Prx nas brânquias após 1 hora de exposição aérea e ausência de alterações dos níveis de GPx (Kuchel et al., 2009). Este resultado significa que os RNAm foram traduzidos ou degradados? Ou a síntese destes foi diminuída, ao passo que a sua tradução ou degradação permaneceram com o mesmo ritmo? Ainda nos moluscos, Pöhlmann et al., (2011) mostraram que, nas brânquias de duas espécies de caramujos marinhos, a atividade de catalase não se alterou frente à exposição aérea (entre duas e 12 horas). Neste estudo, um dos bivalves, Nacella magellanica, foi coletado de duas regiões de regime entre-marés, enquanto que a espécie Nacella deaurata fica sempre imersa, região de sublitoral. Não obstante, nas duas espécies $N$. Magellanica e $N$. deaurata, após 12 horas de exposição aérea, os níveis de atividade de SOD foram aumentados em 57 e 184\%, respectivamente. Porém, na mesma espécie $N$. magellanica, SOD aumentou somente em população de uma determinada região e não em outra. Como explicar esta diferença dentro da mesma espécie? Apesar dos autores não explicarem tal resultado, uma sugestão da variabilidade encontrada é que dadas as informações dos autores, os animais que foram coletados de um determinado local experimentam regimes de maré alta e baixa continuamente, entre duas e quatro horas de exposição aérea, por duas vezes ao dia, enquanto que os outros animais sofrem influencia das marés apenas na época de primavera (Pöhlmann et al., 2011).

Alguns mexilhões possuem seu padrão de distribuição no substrato rochoso de maneira vertical, sendo que alguns indivíduos podem ficar mais perto d'água, com menor tempo de exposição aérea, enquanto os indivíduos distribuídos mais ao alto do rochedo podem passar mais tempo expostos ao ar, nomeadas de baixo e alto rochedo (Tomanek e Somero, 1999). Ao comparar os níveis de atividade de SOD nas brânquias de Mytilus edulis em populações de alto e baixo rochedo, os animais do alto 
rochedo apresentavam maiores níveis constitutivos de atividade de SOD em relação aos animais do rochedo inferior. Ambas as populações não tiveram alteração dos níveis de atividade em resposta à exposição aérea por seis horas e meia (Letrende et al., 2008). No hepatopâncreas, a atividade de SOD de ambas as populações caiu em resposta à uma hora e meia de exposição aérea e voltou ao nível do controle após seis horas de exposição aérea, sem efeitos na atividade de SOD após 30 minutos de reimersão (Letrende et al., 2008). Os mexilhões do alto rochedo, com maiores níveis de SOD, estariam mais protegidos em relação ao estresse da hipóxia e reoxigenação, como resposta a maiores tempos de exposição aérea? Incrivelmente, em outro trabalho, do mesmo grupo, outros antioxidantes (GR, GST, GPx e catalase) em dois tecidos diferentes (brânquias e hepatopâncreas) também tiveram seus níveis de atividade superiores aos animais do baixo rochedo (Letrende et al., 2009). Na maioria dos trabalhos citados anteriormente, os antioxidantes tiveram seus níveis de atividade aumentados frente à exposição aérea, mas em todos os casos, a exposição aérea foi imposta.

A região entre marés é um local conveniente para avaliar o realismo fisiológico em seu contexto natural, em um 'laboratório' natural (Paine, 1966; Spicer, 2014). Neste ambiente, os mexilhões Mytilaster solisianus precisam responder fisiologicamente a estas flutuações diárias da retirada e oferta de $\mathrm{O}_{2}$, em meio a esperadas flutuações termais, e períodos de privação alimentar, e o esperado estresse oxidativo. Mesmo assim, não houve aumento nos níveis de GSH (figura 8) durante o ciclo das marés, apenas uma queda dos níveis de Eq-GSH na coleta III (figura 7). Aparentemente, isto ocorreu não devido à exposição aérea, mas possivelmente pelo estresse da rápida mudança de temperatura do ar. Mas, ao mesmo tempo, não houve alteração da razão GSSG/Eq-GSH (visualmente, é similar às coletas I e II; figura 10), o que indica ausência de maior desbalanço redox. Esses resultados inesperados levam a algumas indagações. Teriam estes animais níveis já suficientes de GSH para responder à exposição aérea e a reimersão, ou estes animais estão controlando a produção de EROs gerados pela mitocôndria (considerado por alguns autores o principal sítio de EROs)? Ou ambos acontecem ao mesmo tempo? É importante citar que outros antioxidantes podem estar respondendo à exposição aérea, como SOD, GPx, GST, GR, Prx e tioredoxina, medidas estas necessárias para um contexto 
completo do sistema antioxidante. Outra pergunta que permanece em questão é: estes animais estão pré-condicionados a este ambiente? Isto implicaria em menor produção de EROs e menor nível de estresse oxidativo? Na coleta III, os animais estavam com os níveis de Eq-GSH relativamente maiores quando comparado com a coleta I e II. O que isto significa? Maior tempo de exposição aérea vivenciado em dias anteriores significa maiores níveis de GSH sintetizados previamente à exposição aérea de modo a responder e controlar o estresse oxidativo? Isto também acontece para outros antioxidantes? No trabalho de Fields et al. (2014), os autores mostraram que mexilhões de ambiente entre marés Geukensia demissa, após passarem por exposição aérea seguida de reimersão por 6, 12 e 18 horas, apresentavam níveis constitutivos aumentados de proteinas antioxidantes (p.ex. Prx, GST). Esta alta manutenção de proteínas antioxidantes já seria uma resposta antecipatória para o estresse ambiental que estaria por vir novamente, o estresse da exposição aérea e reimersão (Fields et al., 2014).

Em dois artigos recentes sobre mudanças de antioxidantes em animais submetidos à privação de $\mathrm{O}_{2}$, com um alto grau de números de artigos citados, curiosamente não houve a descrição de estudos de animais que passam por estresses repetidos ou intermitentes, seja hipóxia ou anóxia (Hermes-Lima et al., 2015; Moreira et al., 2016). Possivelmente, a resposta de animais a um determinado estresse fisiológico (p.ex. hipóxia) difere dependendo de episódios anteriores de estresse. Por exemplo, há aqueles que passam por estresse e que se recuperam por um período qualquer de tempo, há aqueles que que ao longo de sua vida nunca passaram por tal estresse, e há aqueles aclimatados por muito tempo em condições de estresse. Isso leva à pergunta: eles terão necessariamente a mesma resposta para determinado marcador biológico, por exemplo, os antioxidantes (GSH)? A produção mitocondrial de EROs continua a mesma?

É bem sabido pelos cardiologistas que, ao submeter o miocárdio de mamíferos por períodos intermitentes e curtos de isquemia e reperfusão (entre 2-5 minutos), ocorre um aumento da resistência do tecido à morte celular e injúria por estresse oxidativo. Ocorre menor geração de EROs pela mitocôndria. A explicação para esse fenômeno é que EROs produzidos em baixos níveis durante períodos intermitentes e curtos de isquemia e reperfusão disparariam sistemas de sinalização envolvendo a 
resposta adaptativa (como os antioxidantes), entre outros processos na defesa contra a injúria tecidual (Steeves et al., 1994; Gidday, 2006; Halestrap et al., 2007; Penna et al., 2009). Será que, fazendo uma analogia ao ambiente entre marés, com alterações cíclicas dos níveis de $\mathrm{O}_{2}$, isto pode conferir proteção aos animais produzindo menores níveis de EROs? Há um pré e pós-condicionamento evolucionário nesta espécie (entre outras) de zonas entre marés que possibilitam o seu alto grau de adaptabilidade a este ambiente hostil? Esta ideia em que a mediação de um estresse exógeno não letal e que configura proteção ou ganho de adaptabilidade frente à repetição do mesmo estresse se chama Hormesis, 'o que não mata fortalece' (Forbes, 2000; Gems e Partridge 2008; Constantine et al., 2010). Os autores consideram as enzimas antioxidantes e HSPs como efetores horméticos, no qual a mediação de um estresse estimula positivamente estes sistemas, que integradas ao nível de genoma, gene e proteínas, conferem a mediação da adaptabilidade animal frente ao mesmo estresse ou a outros tipos (Gidday, 2006).

Este tipo de procedimento experimental de análise de respostas bioquímicas ao longo do tempo, frente à descida e subida de marés também foi feita por outros autores no campo (Gracey et al., 2008), ou em condições que simulam o regime entre marés, de modo a controlar as variáveis ambientais do campo (Connor e Gracey, 2011). Nestes estudos, focando na análise global da expressão de genes (transcritoma), indicativos de acoplamento de respostas ao estresse na emergência da exposição aérea acontecem na espécie Mytilus californianus, os autores mostraram que mudanças rítmicas e diferenciais de expressão gênica ocorrem em resposta à exposição aérea. Ocorre aumento dos níveis de expressão de genes que respondem à elevação termal, como as proteínas de choque térmico (HSP70 e 90), sendo que estes genes são mais expressos em populações de alto rochedo quando comparada com os animais de baixo rochedo (Gracey et al., 2008). Será que as HSPs estariam aumentadas em resposta à exposição aérea em Mytilaster solisianus? Sobre os antioxidantes, houve a detecção de transcritos para GST, Prx e GPx que foram aumentados em resposta à exposição aérea (Gracey et al., 2008). Interessantemente, nos mamíferos sensíveis à injúria da isquemia e reperfusão, os níveis de RNAm para SOD, catalase e GPx caem no tecido renal, bem como os seus níveis de atividade e proteicos (Dobashi et al., 2000). 
Interessantemente, Zhang et al., (2012), ao estudarem o genoma (sequenciamento) e transcritoma da ostra Crassostrea gigas que vive em regiões entre marés, e mediarem exposição aérea por vários dias (entre 1 a 10 dias), observaram que esta espécie possui diferentes cópias de genes para HSP70, GST, BAX (do inglês BCL2-associated X protein) e BCL2 (do inglês B cell linfoma 2), com um número superior de cópias destes genes ao encontrado em outras espécies, e seus transcritos aumentam em resposta à exposição aérea, incluindo PRX. Ao mediar estresse termal nesta espécie, houve aumento dos transcritos de HSP70 em torno de 2000 vezes (Zhang et al., 2014). Os autores explicam que a grande corrente de genes com funções anti-apoptose (BLC2, BAX e GST), em conjunto com altos níveis de expressão de HSPS, configuram a adaptabilidade destes animais a este ambiente, que podem experimentar no verão temperaturas em torno de $49^{\circ} \mathrm{C}$ (Zhang et al., 2012). Logo, esta espécie teria todo um arsenal bioquímico que confere adaptabilidade a este ambiente. Isto também acontece em Mytilaster solisianus? Caso sim, isto explicaria em parte a forte tolerância destes animais ao insulto do estresse termal observado na coleta III?

\section{CONCLUSÕES E PERSPECTIVAS}

Nos animais que não toleram a privação de $\mathrm{O}_{2}$, é observada a injúria tecidual durante a hipóxia e reoxigenação, tendo como causa principal o estresse oxidativo. Este trabalho inicial, estudando hipóxia e reoxigenação ambiental induzida pela baixa e alta da maré, mostrou que os parâmetros de GSH mantiveram-se inalterados no ciclo das marés nas duas coletas (apesar do P de 0,06 para a coleta I), e que houve uma queda dos níveis totais de Eq-GSH após duas horas de exposição aérea em relação aos animais pré-imersos na coleta III. Porém, o indicador de estresse oxidativo não sofreu mudanças (razão GSSG/Eq-GSH). Como houve queda do pool de GSH, e que visualmente parece estar ocorrendo também baixa de GSH e GSSG, é possível que GST possa estar mais ativa nos momentos iniciais de exposição aérea, pois é uma rota de uso de GSH que não produz GSSG (Sheehan et al., 2001)). Outra hipótese é que durante a transição água para o ar na coleta III a GSH possa esta ligada a proteínas (S-glutationilação). Pois parece que esta coleta tem maior nível de estresse 
ambiental do que na coleta I e II (maior tempo de exposição aérea e maior variação termal), de modo a S-glutationilação protege as proteínas de modificações irreversíveis promovida por radicais livres (Dalle-Donne et al., 2007).

É possível que outros antioxidantes possam estar respondendo em termos de atividade enzimática ao estresse termal agudo sofrido pelos animais ou à exposição aérea. Análises adicionais estão sendo feitas para responder esta pergunta, o que poderá mostrar uma visão global da manutenção do equilíbrio redox observado nestes animais. Outros experimentos poderiam ajudar a responder essas perguntas, por exemplo, uma análise comparativa entre as condições do ambiente com uma situação controle, com as variáveis de exposição aérea, temperatura e umidade controladas. Seria interessante no futuro investigar outros sistemas de resposta ao estresse ambiental, como HSPs, BAX, BLC2, quinases ativadas em resposta a estresse termal e hipóxico (p.ex. MAPK), incluindo fatores de transcrição induzidos por hipóxia (HIF) ou que respondem ao estresse oxidativo (Nrf2, FOXO), enzimas relacionadas com o ganho de longevidade (sirtuínas), e um estudo de metabolômica com fins específicos, buscando medir: succinato, hipoxantina e xantina, NAD(P)H e NAD(P), AMP, ADP, ATP; ceramida, carnitina, acil-carnitina, triacilglicerol, malato, alanina, octopino, alanopino, estrombino, fosfo-arginina, tioredoxina (reduzida e oxidada), citrato, isocitrato, glicose e fosfoenolpiruvato. Outro ponto importante também seria avaliar a atividade da oxidase alternativa, encontrada em animais marinhos, esta enzima evita a formação de EROs por reduzir $\mathrm{O}_{2}$ em água (função similar a do complexo IV da mitocôndria) (Welker et al., 2013).

\section{REFERÊNCIAS BIBLIOGRÁFICAS}

Abele D, Heise K, Pörtner HO, Puntarulo S. Temperature-dependence of mitochondrial function and production of reactive oxygen species in the intertidal mud clam Mya arenaria. J Exp Biol. 2002 Jul;205(Pt 13):1831-41.

Abele D, Strahl J, Brey T, Philipp EE. Imperceptible senescence: ageing in the ocean quahog Arctica islandica. Free Radic Res. 2008 May;42(5):474-80.

Almeida, E A; Bainy, A C D. Effects of aerial exposure on antioxidant defenses in the brown mussel Perna perna. Braz. Arch. Biol. Technol. 2006 Mar;49:225-229.

Agardh CD, Gustavsson C, Hagert P, Nilsson M, Agardh E. Expression of antioxidant enzymes in rat retinal ischemia followed by reperfusion. Metabolism. 2006 Jul;55(7):892-8. 
Akerboom TP, Sies H. Assay of glutathione, glutathione disulfide, and glutathione mixed disulfides in biological samples. Methods Enzymol. 1981;77:373-82.

Almeida EA, Bainy ACD, Dafré AL, Gomes OF, Medeiros MHG, Di Mascio P. Oxidative stress in digestive gland and gill of the brown mussel (Perna perna) exposed to air and re-submersed. J Exp Mar Biol Ecol. 2005 May;318:21-30.

Anestis A, Lazou A, Pörtner HO, Michaelidis B. Behavioral, metabolic, and molecular stress responses of marine bivalve Mytilus galloprovincialis during longterm acclimation at increasing ambient temperature. Am J Physiol Regul Integr Comp Physiol. 2007 Aug;293(2):R911-21.

Ansaldo M, Sacristán H, Wider E. Does starvation influence the antioxidant status of the digestive gland of Nacella concinna in experimental conditions? Comp Biochem Physiol C Toxicol Pharmacol. 2007 Jul-Aug;146(1-2):118-23.

Anwar NA, Richardson CA, Seed R. Age determination, growth rate and population structure of the horse mussel Modiolus modiolus. J Mar Biol Assoc UK. 1990 May;70 (2):441-457.

Ayene IS, Dodia C, Fisher AB. Role of oxygen in oxidation of lipid and protein during ischemia/reperfusion in isolated perfused rat lung. Arch Biochem Biophys. 1992 Jul;296(1):183-9.

Bayne BL, Bayne CL, Carefoot TC, Thompson RJ. The physiological ecology of Mytilus californianus Conrad. 2. Adaptations to low oxygen tension and air exposure. Oecologia.1976 Sep; 22:29-50.

Bolli R, Jeroudi MO, Patel BS, DuBose CM, Lai EK, Roberts R, McCay PB. Direct evidence that oxygen-derived free radicals contribute to postischemic myocardial dysfunction in the intact dog. Proc Natl Acad Sci U S A. 1989 Jun;86(12):4695-9.

Canesi L, Viarengo A. Age-related differences in glutathione metabolism in mussel tissues (Mytilus edulis L.) Comp Biochem Physiol Part B Biochem Mol Biol. 1997 Feb; 116(2):217-221.

Caito SW, Aschner M. Quantification of Glutathione in Caenorhabditis elegans. Curr Protoc Toxicol. 2015 May;64(618):6.18.1-6.18.6.

Chakravarthi S, Jessop CE, Bulleid NJ.The role of glutathione in disulphide bond formation and endoplasmic-reticulum-generated oxidative stress. EMBO Rep. 2006 Mar;7(3):271-275.

Chen MY, Yang HS, Delaporte M, Zhao SJ, Xing K. Immune responses of the scallop Chlamys farreri after air exposure to different temperatures. J Exp Mar Biol Ecol. 2007 Jun;345:52-60.

Chen YR, Zweier JL. Cardiac mitochondria and reactive oxygen species generation. Circ Res. 2014 Jan;114(3):524-37.

Chouchani ET, Pell VR, Gaude E, Aksentijević D, Sundier SY, Robb EL, Logan A, Nadtochiy SM, Ord EN, Smith AC, Eyassu F, Shirley R, Hu CH, Dare AJ, James AM, Rogatti S, Hartley RC, Eaton S, Costa AS, Brookes PS, Davidson SM, Duchen MR, Saeb-Parsy K, Shattock MJ, Robinson AJ, Work LM, Frezza C, Krieg T, Murphy MP. Ischaemic accumulation of succinate controls reperfusion injury through mitochondrial ROS. Nature. 2014 Nov; 20;515(7527):431-5.

Connor KM, Gracey AY. Circadian cycles are the dominant transcriptional rhythm in the intertidal mussel Mytilus californianus. Proc Natl Acad Sci U S A. 2011 Sep 20;108(38):16110-5. 
Connor KM, Gracey AY. High-resolution analysis of metabolic cycles in the intertidal mussel Mytilus californianus. Am J Physiol Regul Integr Comp Physiol. 2012 Jan 1;302(1):R103-11.

Costantini D, Metcalfe NB, Monaghan P. Ecological processes in a hormetic framework. Ecol Lett. 2010 Nov;13(11):1435-47.

Czaja MJ, Schilsky ML, Xu Y, Schmiedeberg P, Compton A, Ridnour L, Oberley LW. Induction of MnSOD gene expression in a hepatic model of TNF-alpha toxicity does not result in increased protein. Am J Physiol. 1994 Apr;266(4 Pt 1):G737-44.

Dafre AL, Medeiros ID, Müller IC, Ventura EC, Bainy AC. Antioxidant enzymes and thiol/disulfide status in the digestive gland of the brown mussel Perna perna exposed to lead and paraquat. Chem Biol Interact. 2004 Oct 15;149(2-3):97-105.

Dalle-Donne I, Rossi R, Giustarini D, Colombo R, Milzani A. S-glutathionylation in protein redox regulation. Free Radic Biol Med. 2007 Sep 15;43(6):883-98.

Dawson NJ, Storey KB. Regulation of tail muscle arginine kinase by reversible phosphorylation in an anoxia-tolerant crayfish. J Comp Physiol B. 2011 Oct;181(7):851-9.

Dirksen MT, Laarman GJ, Simoons ML, Duncker DJ. Reperfusion injury in humans: a review of clinical trials on reperfusion injury inhibitory strategies. Cardiovasc Res. 2007 Jun;74(3):343-55.

Doyotte A, Cossu C, Jacquin MC, Babut M, Vasseur P. Antioxidant enzymes, glutathione and lipid peroxidation as relevant biomarkers of experimental or field exposure in the gills and the digestive gland of the freshwater bivalve Unio tumidus. Aquat Toxicol. 1997 Jan;39:93-1 10.

Dowd WW, Felton CA, Heymann HH, Kost LE, Somero GN. Food availability,more than body temperature, drives correlated shifts in ATP-generating and antioxidant enzyme capacities in a population of intertidal mussels (Mytilus californianus). J Exp Mar Biol Ecol. 2013 Nov;449: 171-185.

Eaton P, Li JM, Hearse DJ, Shattock MJ. Formation of 4-hydroxy-2-nonenalmodified proteins in ischemic rat heart. Am J Physiol. 1999 Mar;276(3 Pt 2):H93543.

Ellington WR. Evolution and physiological roles of phosphagen systems. Annu Rev Physiol. 2001 Marc;63:289-325.

Eyer P, Worek F, Kiderlen D, Sinko G, Stuglin A, Simeon-Rudolf V, Reiner E. Molar absorption coefficients for the reduced Ellman reagent: reassessment. Anal Biochem. 2003 Jan;312(2):224-7.

Fields PA, Eurich C, Gao WL, Cela B. Changes in protein expression in the salt marsh mussel Geukensia demissa: evidence for a shift from anaerobic to aerobic metabolism during prolonged aerial exposure. J Exp Biol. 2014 May;217(Pt 9):160112.

Forbes VE. Is hormesis an evolutionary expectation. Funct Ecol. 2000 Feb; 14:12-24. Franco JL, Trivella DB, Trevisan R, Dinslaken DF, Marques MR, Bainy AC, Dafre AL. Antioxidant status and stress proteins in the gills of the brown mussel Perna perna exposed to zinc. Chem Biol Interact. 2006 Apr;160(3):232-40.

Freire CA, TognI VG, Hermes-lima M. Responses of free radical metabolism to air exposure or salinity stress, in crabs (Callinectes danae and C. ornatus) with different estuarine distributions. Comp Biochem Physiol A Mol Integr Physiol.2011a Oct;160(2):291-300. 
Freire CA, Welker AF, Storey JM, Storey KB, Hermes-lima, M. Oxidative stress in estuarine and intertidal species. Oxidative stress in aquatic ecosystems. First Edition. In Abele, D., Vázquez-Medina J.P., Zenteno-Savín T. (Eds). Wiley Blackwell, New York, 2011b Nov;41-57.

Gade G. Effects of oxygen deprivation during anoxia and muscular work on the energy metabolism of the crayfish, Orconectes limosus. Comp Biochem Physiol A Mol Integr Physiol. 1984, 77:495-502.

Galton DJ. Lamarckian inheritance and epigenetics: is there a connection? Int $\mathbf{J}$ Epidemiol. 2016 Feb;45(1):23-5.

Gems D, Partridge L. Stress-response hormesis and aging: "that which does not kill us makes us stronger". Cell Metab. 2008 Mar;7(3):200-3.

Gidday JM. Cerebral preconditioning and ischaemic tolerance. Nat Rev Neurosci. 2006 Jun;7(6):437-48.

González RR, Quiñones RA. Pyruvate oxidoreductases involved in glycolytic anaerobic metabolism of polychaetes from the continental shelf off central-south Chile. Estuarine, Coastal and Shelf Science. 2000 Oct;51(4):507-519.

Gracey AY, Chaney ML, Boomhower JP, Tyburczy WR, Connor K, Somero GN. Rhythms of gene expression in a fluctuating intertidal environment. Curr Biol. 2008 Oct; 18:1501-1507.

Griffith OW. Determination of glutathione and glutathione disulfide using glutathione reductase and 2-vinylpyridine. Anal Biochem. $1980 \mathrm{Jul}$;106(1):207-12.

Griffith OW. Biologic and pharmacologic regulation of mammalian glutathione synthesis. Free Radic Biol Med. 1999 Nov;27(9-10):922-35.

Halestrap AP, Clarke SJ, Khaliuin I. The role of mitochondria in protection of the heart by preconditioning. Biochim Biophys Acta. 2007 Aug; 1767(8): 1007-1031.

Hartwig K, Heidler T, Moch J, Daniel H, Wenzel U. Feeding a ROSgenerator to Caenorhabditis elegans leads to increased expression of small heat shock protein HSP62 and hormesis. Genes Nutr. 2009 Mar;4(1):59-67.

Hatem E, Berthonaud V, Dardalhon M, Lagniel G, Baudouin-Cornu P, Huang ME, Labarre J, Chédin S. Glutathione is essential to preserve nuclear function and cell survival under oxidative stress. Free Radic Biol Med. 2014 Feb;67:103-14.

Hermes-Lima M, Moreira DC, Rivera-Ingraham GA, Giraud-Billoud M, GenaroMattos TC, Campos ÉG. Preparation for oxidative stress under hypoxia and metabolic depression: Revisiting the proposal two decades later. Free Radic Biol Med. 2015 Dec;89:1122-43.

Hermes-Lima M, Storey JM, Storey KB. Antioxidant defenses and metabolic depression. The hypothesis of preparation for oxidative stress in land snails. Comp Biochem Physiol B Biochem Mol Biol. 1998 Jul;120(3):437-48.

Hermes-Lima M, Zenteno-Savín T. Animal response to drastic changes in oxygen availability and physiological oxidative stress. Comp Biochem Physiol C Toxicol Pharmacol. 2002 Dec;133(4):537-56.

Hickey AJ, Renshaw GM, Speers-Roesch B, Richards JG, Wang Y, Farrell AP, Brauner CJ. A radical approach to beating hypoxia: depressed free radical release from heart fibres of the hypoxia-tolerant epaulette shark (Hemiscyllum ocellatum). $\mathrm{J}$ Comp Physiol B. 2012 Jan;182(1):91-100.

Hochachka PW, Buck LT, Doll CJ, Land SC. Unifying theory of hypoxia tolerance: Molecular/metabolic defense and rescue mechanisms for surviving oxygen lack. Proc Natl Acad Sci U S A. 1996 Sep; 93(18): 9493-9498. 
Hochachka PW, Lutz PL. Mechanism, origin, and evolution of anoxia tolerance in animals. Comp Biochem Physiol B Biochem Mol Biol. 2001 Dec;130(4):435-59.

Hochachka PW, Somero GN. Biochemical adaptation: mechanism and process in physiological evolution. 2002 Oxford; New York: Oxford University Press.

Honda HM, Korge P, Weiss JN. Mitochondria and ischemia/reperfusion injury. Ann N Y Acad Sci. 2005 Jun;1047:248-58.

Işlekel S, Işlekel H, Güner G, Ozdamar N. Alterations in superoxide dismutase, glutathione peroxidase and catalase activities in experimental cerebral ischemiareperfusion. Res Exp Med (Berl). 1999 Dec;199(3):167-76.

Kalyanaraman B, Darley-Usmar V, Davies KJ, Dennery PA, Forman HJ, Grisham MB, Mann GE, Moore K, Roberts LJ, Ischiropoulos H. Measuring reactive oxygen and nitrogen species with fluorescent probes: challenges and limitations. Free Radic Biol Med. 2012 Jan 1;52(1):1-6.

Kuppusamy P, Zweier JL. Characterization of free radical generation by xanthine oxidase. Evidence for hydroxyl radical generation. J Biol Chem. 1989 Jun 15;264(17):9880-4.

Krebs HA. The August Krogh Principle: "For many problems there is an animal on which it can be most conveniently studied". J Exp Zool. 1975 Oct;194(1):221-6.

Lee MC, Velayutham M, Komatsu T, Hille R, Zweier JL. Measurement and characterization of superoxide generation from xanthine dehydrogenase: a redoxregulated pathway of radical generation in ischemic tissues. Biochemistry. 2014 Oct 21;53(41):6615-23.

Lesser MP. Oxidative stress in marine environments: biochemistry and physiological ecology. Annu Rev Physiol. 2006 Mar;68:253-78.

Letendre J, Chouquet B, Rocher, B, Manduzio H, Leboulenger F, Durand F. Differential pattern of $\mathrm{Cu} / \mathrm{Zn}$ superoxide dismutase isoforms in relation to tidal spatio-temporal changes in the blue mussel Mytilus edulis. Comp Biochem Physiol C Toxicol Pharmacol. 2008 Sep;148(3):211-6.

Letendre J, Chouquet B, Manduzio H, Marin M, Bultelle F, Leboulenger F, Durand F, Tidal height influences the levels of enzymatic antioxidant defences in Mytilus edulis. Mar Environ Res. 2009 Mar;67(2):69-74.

Lushchak VI. Adaptive response to oxidative stress: Bacteria, fungi, plants and animals. Comp Biochem Physiol C Toxicol Pharmacol. 2011 Mar;153(2):175-90.

Mailloux RJ, Willmore WG. S-glutathionylation reactions in mitochondrial function and disease. Front Cell Dev Biol. 2014 Nov 17;2:68.

Marí M, Morales A, Colell A, García-Ruiz C, Fernández-Checa JC. Mitochondrial glutathione, a key survival antioxidant. Antioxid Redox Signal. 2009 Nov;11(11):2685-700.

McCord JM. Oxygen-derived free radicals in postischemic tissue injury. N Engl J Med. 1985 Jan;312(3):159-63.

Meister A, Anderson ME. Glutathione. Annu Rev Biochem. 1983 Jul;52:711-60.

Milton SL, Nayak G, Kesaraju S, Kara L, Prentice HM. Suppression of reactive oxygen species production enhances neuronal survival in vitro and in vivo in the anoxia-tolerant turtle Trachemys scripta. J Neurochem. 2007 May;101(4):993-1001.

Mitchelmorea CL, Ringwoodb AH, Weisa VM. Differential accumulation of cadmium and changes in glutathione levels as a function of symbiotic state in the sea anemone Anthopleura elegantissima. J Exp Mar Biol Ecol. 2003 Jan; 284:71-85. 
Moreira DC, Venancio LP, Sabino MA, Hermes-Lima M. How widespread is preparation for oxidative stress in the animal kingdom? Comp Biochem Physiol A Mol Integr Physiol. 2016 Feb. pii: S1095-6433(16)30018-6.

Pannunzio TM, Storey KB. Antioxidant defenses and lipid peroxidation during anoxia stress and aerobic recovery in the marine gastropod Littorina littorea. J Exp Mar Biol Ecol. 1998; 221:277-292.

Penna C, Mancardi D, Rastaldo R, Pagliaro P. Cardioprotection: a radical view Free radicals in pre and postconditioning. Biochim Biophys Acta. 2009 Jul;1787(7):78193.

Philipp EE, Abele D. Masters of Longevity: Lessons from Long-Lived Bivalves - A Mini-Review. Gerontology. 2010;56(1):55-65.

Pöhlmann K, Koenigstein S, Alter K, Abele D, Held C. Heatshock response and antioxidant defense during air exposure in Patagonian shallowwater limpets fromdifferent climatic habitats. Cell Stress Chaperon. 2011 Nov;16(6):621-32.

Organização mundial de saúde (OMS). Mortes por doenças coronárias cardíacas. http://www.who.int/mediacentre/factsheets/fs317/en/. Acesso em: 28.05.2015.

Paine RT. Food web complexity and species diversity. Amer Nat. 1966 Jan-fev; 100(910):65-75.

Singh I, Gulati S, Orak JK, Singh AK. Expression of antioxidant enzymes in rat kidney during ischemia-reperfusion injury. Mol Cell Biochem. 1993 Aug 25;125(2):97-104.

Rahman I, Kode A, Biswas SK. Assay for quantitative determination of glutathione and glutathione disulfide levels using enzymatic recycling method. Nat Protoc. 2006; 1:3159-3165.

Regoli F, Principato G. Glutathione, glutathione-dependent and antioxidant enzymes in mussel, Mytilus galloprovincialis, exposed to metals under field and laboratory conditions: implications for the use of biochemical biomarkers. Aquat Toxicol. 1995 Feb;31:143-164.

Rivera-Ingraham GA, Bickmeyer U, Abele D. The physiological response of the marine platyhelminth Macrostomum lignano to different environmental oxygen concentrations. J Exp Biol. 2013a Jul;216(Pt 14):2741-51.

Rivera-Ingraham GA, Rocchetta I, Meyer S, Abele D. Oxygen radical formation in anoxic transgression and anoxia-reoxygenation: foe or phantom? Experiments with a hypoxia tolerant bivalve. Mar Environ Res. 2013b Dec;92:110-9.

Romero MC, Ansaldo M, Lovrich GA. Effect of aerial exposure on the antioxidant status in the subantarctic stone crab Paralomis granulosa (Decapoda: Anomura). Comp Biochem Physiol C Toxicol Pharmacol. 2007 Jul-Aug;146(1-2):54-9.

Sato M, Takeuchi M, Kanno N, Nagahisa E, Sato Y. Distribution of opine dehydrogenases and lactate dehydrogenase activities in marine animals.

Comp Biochem Physiol B Biochem Mol Biol. 1993 Dec; 106(4):955-960.

Semenza GL. Hypoxia-inducible factor 1 (HIF-1) pathway. Sci STKE. 2007 Oct 9;2007(407):cm8.

Sheehan D, Meade G, Foley VM, Dowd CA. Structure, function and evolution of glutathione transferases: implications for classification of non-mammalian members of an ancient enzyme superfamily. Biochem J. 2001 Nov 15; 360(Pt 1): 1-16.

Spicer JI. What can an ecophysiological approach tell us about the physiological responses of marine invertebrates to hypoxia? J Exp Biol. 2014 Jan. 217:46-56. 
Steeves G, Singh N, Singal PK. Preconditioning and antioxidant defense against reperfusion injury. Ann N Y Acad Sci. 1994 Jun;723:116-27.

Strahl J, Brey T, Philipp EE, Thorarinsdóttir G, Fischer N, Wessels W, Abele D. Physiological responses to self-induced burrowing and metabolic rate depression in the ocean quahog Arctica islandica. J Exp Biol. 2011 Dec 15;214(Pt 24):4223-33.

Teixeira T, Diniz M, Calado R, Rosa R. Coral physiological adaptations to air exposure: heat shock and oxidative stress responses in Veretillum cynomorium. J. Exp. Mar. Biol. Ecol. 2013; 439, 35-41.

Tessmar-Raible K, Raible F, Arboleda E. Another place, another timer: Marine species and the rhythms of life. Bioessays. 2011 Mar; 33(3): 165-172.

Tomanek L, Somero GN. Evolutionary and acclimation-induced variation in the heatshock responses of congeneric marine snails (genus tegula) from different thermal habitats: implications for limits of thermotolerance and biogeography. $J$ Exp Biol. 1999;202(Pt 21):2925-2936.

Trevisan R, Arl M, Sacchet CL, Engel CS, Danielli NM, Mello DF, Brocardo C, Maris AF, Dafre AL. Antioxidant deficit in gills of Pacific oyster (Crassostrea gigas) exposed to chlorodinitrobenzene increases menadione toxicity. Aquat Toxicol. 2012 Feb;108:85-93.

Vaiserman AM. Hormesis and epigenetics: is there a link? Ageing Res Rev. 2011 Sep;10(4):413-21.

Valls-Lacalle L, Barba I, Miró-Casas E, Alburquerque-Béjar JJ, Ruiz-Meana M, Fuertes-Agudo M, Rodríguez-Sinovas A, García-Dorado D. Succinate dehydrogenase inhibition with malonate during reperfusion reduces infarct size by preventing mitochondrial permeability transition. Cardiovasc Res. 2016 Mar;109(3):374-84.

Zweier JL, Flaherty JT, Weisfeldt ML. Direct measurement of free radical generation following reperfusion of ischemic myocardium. Proc Natl Acad Sci U S A. 1987 Mar; 84(5): 1404-1407.

Zweier JL, Kuppusamy $\quad$ P, Williams $\quad$ R, Rayburn $\quad$ BK, Smith $\quad$ D, Weisfeldt ML, Flaherty JT. Measurement and characterization of postischemic free radical generation in the isolated perfused heart. J Biol Chem. 1989 Nov;264(32):18890-5.

Xia Y, Zweier JL. Substrate control of free radical generation from xanthine oxidase in the postischemic heart. J Biol Chem. 1995 Aug;270(32):18797-803.

Wang P, Chen H, Qin H, Sankarapandi S, Becher MW, Wong PC, Zweier JL. Overexpression of human copper,zinc-superoxide dismutase (SOD1) prevents postischemic injury. Proc Natl Acad Sci U S A. 1998 Apr; 95(8): 4556-4560.

Weihe E, Kriews M, Abele D. Differences in heavy metal concentrations and in the response of the antioxidant system to hypoxia and air exposure in the Antarctic limpet Nacella concinna. Mar Environ Res. 2010 Apr;69(3):127-35.

Weydert CJ, Cullen JJ. Measurement of superoxide dismutase, catalase and glutathione peroxidase in cultured cells and tissue. Nat Protoc. 2010 Jan;5(1):51-66.

Welker AF. Efeitos da flutuação da disponibilidade de oxigênio e da privação alimentar sobre o metabolismo de radicais livres. Tese de Doutorado, 2009. Universidade de São Paulo, Brasil.

Welker AF, Campos EG, Cardoso LA, Hermes-Lima M. Role of catalase on the hypoxia/reoxygenation stress in the hypoxia-tolerant Nile tilapia. Am J Physiol Regul Integr Comp Physiol. 2012 May;302(9):R1111-8. 
Welker AF, Moreira DC, Campos ÉG, Hermes-Lima M. Role of redox metabolism for adaptation of aquatic animals to drastic changes in oxygen availability. Comp Biochem Physiol A Mol Integr Physiol. 2013 Aug;165(4):384-404.

Widdows J, Shick JM. Physiological responses of Mytilus edulis and Cardium edule to aerial exposure. Mar Biol. 1985 Mar; 85:217-232.

Willmore WG, Storey KB. Antioxidant systems and anoxia tolerance in a freshwater turtle Trachemys scripta elegans. Mol Cell Biochem. 1997 May;170(1-2):177-85.

Wu G, Fang YZ, Yang S, Lupton JR, Turner ND. Glutathione metabolism and its implications for health. J Nutr. 2004 Mar;134(3):489-92. 


\section{CAPÍTULO 2 - MANUSCRITO 2: HOW WIDESPREAD IS PREPARATION FOR OXIDATIVE STRESS IN THE ANIMAL KINGDOM?}

Este capítulo é constituído por artigo que foi aceito para publicação e já esta disponível em formato on-line (in press) na base de dados do pubmed ou sciencedirect. Nele, mostramos dados de uma meta-análise de respostas do sistema antioxidante (envolvendo enzimas e moléculas de baixo peso molecular) em diferentes situações de privação de $\mathrm{O}_{2}$, como hipóxia, anóxia, exposição aérea, congelamento, dessecamento. Também foi incluindo no artigo a resposta antioxidante de animais que estivam (não necessariamente experimentam hipóxia, mas entram em depressão metabólica). O aumento das defesas antioxidantes em resposta a estes estresses é chamado de preparo para o estresse oxidativo, do inglês preparation for oxidative stress (POS). A pergunta do artigo é: quantos animais fazem POS? Tem um número significante de animais? Como definir o POS? Basta um antioxidante aumentar para chamar de POS? Se ocorrer a queda de um antioxidante ele não é POS? Critérios para definir o POS também foram elencados (três critérios). Além disto, foram incluídos quase todos os artigos publicados que mediram pelo menos um antioxidante nas situações de privação de $\mathrm{O}_{2}$ anteriores, artigos procurados no pubmed, sciencedirect, scopus e google scholar. Mostramos em termos numéricos a porcentagem $(\%)$ de mudanças que ocorrem nos antioxidantes que atuam diretamente sobre os radicais livres (GSH, catalase, SOD, GST, GPX, metalotioneína), desde os níveis de expressão gênica, níveis proteicos e análise de atividade enzimática. Estudos que envolvem a análise de transcritoma e proteômica também foram incluídos. Boa parte dos animais estudados respondem com o sistema antioxidante dentro dos vários níveis de organização biológica citados, e este fenômeno é observado desde corais (invertebrados) até mamíferos (vertebrados).

Abaixo, a referência para o artigo, bem como o link para o acesso:

Moreira DC, Venancio LP, Sabino MA, Hermes-Lima M. How widespread is preparation for oxidative stress in the animal kingdom? Comp Biochem Physiol A Mol Integr Physiol. 2016 Feb. pii: S1095-6433(16)30018-6. Disponível em: http://www.ncbi.nlm.nih.gov/pubmed/26851497 Acesso em: 12.07.2016. 


\section{DISCUSSÃO GERAL E CONCLUSÕES}

Neste trabalho foram monitorados os parâmetros de GSH durante ciclos naturais de marés em mexilhões da espécie Mytilaster solisianus, com uma robusta e representativa população de 146 espécimes de animais. Na mesma rocha de coleta, fez-se um perfil de possíveis mudanças relacionadas ao status redox em análise de corpo inteiro envolvendo GSH, uma quantificação temporal dentro do mesmo espaço, na mesma praia, em diferentes épocas, em um ambiente no qual os fatores abióticos mudam e podem flutuar periodicamente durante a descida e subida das marés, com menor ou maior tempo de exposição aérea, com a ocorrência ou não de mudanças de temperatura ambiente. E mesmo assim, nestas condições de extremo fisiológico, os mexilhões mostraram manter a homeostase redox, devido à ausência do aumento dos indicadores de estresse oxidativo e desequilíbrio redox, analisados por GSSG e razão GSSG/Eq-GSH, e principalmente na coleta de número III, na qual os animais experimentaram uma alta temperatura ambiente de $28^{\circ} \mathrm{C}$.

Em relação às correlações, houve um padrão de queda entre os níveis de EqGSH e GSH em relação ao peso e tamanho (figuras 16, 17, e 20 e 21). Alguns trabalhos mostram que os níveis Eq-GSH diminuem com o aumento da idade no mexilhão Mytilus edulis, assim como as enzimas envolvidas no seu metabolismo, como glutamil-cisteína ligase (etapa limitante para a biossíntese de GSH) e GST, com ocorrência de baixos níveis de atividade enzimática, nos dois tecidos analisados, brânquias e hepatopâncreas (Canesi e Viarengo, 1997). Porém, estes autores observaram que GR, que renova GSH a partir de GSSG e NADPH, tem seus níveis de atividade aumentados nas brânquias (tecido com níveis maiores de GSH do que o hepatopâncreas nesta espécie), compensando a baixa da síntese de GSH (Canesi e Viarengo, 1997). A queda dos níveis de GSH com o decorrer da idade também é observada em Arctica islandica (Abele et al., 2008). Não é possível dizer qual a idade exata dos mexilhões analisados neste trabalho, mas a ideia corrente é que quanto maiores forem os mexilhões e outros moluscos, mais velhos são os animais (Anwar et al., 1990, Abele et al., 2008).

Cada espécie animal tem seu grau de tolerância a variações de temperatura ambiental e a privação de $\mathrm{O}_{2}$, algumas podem ser mais ou menos sensíveis às 
mudanças destes fatores abióticos, assim como os seus órgãos e tecidos podem responder de maneira diferente. Em determinados animais, níveis reduzidos de $\mathrm{O}_{2}$ podem ser tidos como "hipóxia", para outros animais não. Por exemplo, analisando uma espécie de tubarão tolerante e outra sensível a hipóxia, para que os dois tubarões tivessem o mesmo nível de oxigênio sanguíneo na mediação da hipóxia, na espécie resistente à hipóxia, a quantidade de $\mathrm{O}_{2}$ imposta foi de dois kpa (10\% da saturação de oxigênio na água), enquanto na espécie sensível à hipóxia foi mediado três kpa (15\% da saturação de oxigênio) (Hickey et al., 2012). Segundo os autores, a hemoglobina da espécie tolerante, tem alto grau de afinidade por $\mathrm{O}_{2}$, e na natureza, estes animais vivenciam episódios intermitentes de hipóxia durante a baixa da maré em regiões de recife, e interessantemente, a mitocôndria cardíaca destes animais em resposta à hipóxia produziu menos $\mathrm{H}_{2} \mathrm{O}_{2}$ quando comparado com a espécie sensível à hipóxia (Hickey et al., 2012).

Neste contexto, os mexilhões Mytilaster solisianus ficam em hipóxia na exposição aérea? E por que não anóxia? Eles produzem menos EROs? A exposição aérea é sinônimo da completa ausência de $\mathrm{O}_{2}$ ? A resposta vai depender da espécie animal em questão, talvez o termo correto a se definir seja hipoxemia fisiológica e não anóxia. Por exemplo, no trabalho clássico de Bayne et al., (1976), estudando o mexilhão Mytilus californianus, em resposta a uma hora de exposição aérea, a $\mathrm{pO}_{2}$ na cavidade do manto cai para $24 \mathrm{mmHg}$, e se mantém constante por seis horas de exposição aérea, retornando aos valores normóxicos de $125 \mathrm{mmHg}$ após dois minutos de reimersão. Por outro lado, durante os primeiros minutos de reimersão, o consumo de $\mathrm{O}_{2}$ pelos animais é cerca de duas vezes mais do que os animais na fase imersa e anterior à exposição aérea, desta maneira, rapidamente os animais 'pagam' o débito de $\mathrm{O}_{2}$ adquirido na exposição aérea (Bayne et al., 1976), seria a queima oxidativa pelos altos níveis de $\mathrm{O}_{2}$ consumidos? Outras espécies de mexilhões, Mytilus edulis e Cardium edule, também tiveram a mesma resposta fisiológica como observado em Mytilus californianus (Widdows e Shick, 1985). Em três diferentes espécies de mexilhões marinhos, os autores mostraram que os animais apresentaram uma capacidade de consumir $\mathrm{O}_{2}$ do ar de 0,7 vezes em relação aos animais na água (Bayne et al., 1976). Na transição água para a exposição aérea, há uma diminuição da atividade cardíaca de 25 para cinco batimentos por minuto (bpm), sendo o normal 
para esta espécie, e se mantém os mesmos cinco bpms por 1 hora de exposição aérea, com a posterior reimersão, em cinco minutos há o retorno da atividade cardíaca, e até ultrapassando os 25 bpms após dez minutos de reimersão (Bayne et al., 1976). Este padrão de alteração da frequência cardíaca em resposta à emersão e reimersão em Mytilus californianus foi confirmado por Connor et al., (2012).

Alguns mexilhões têm o comportamento de abrir e fechar a concha em resposta à exposição aérea, como forma de aumentar a troca de gases (aumentar a captação de $\mathrm{O}_{2}$ ), como a espécie de mexilhão Geukenssia demissa. Porém ao abrir e fechar a concha, estes animais têm considerada perda de água, e ocorrência de estresse fisiológico por dessecação (Fields et al., 2014). Neste trabalho, durante o período de coleta, observou-se que os mexilhões mantém a concha fechada durante a exposição aérea, e quando reimersos eles abrem a mesma. Eu abri alguns animais no decorrer da exposição aérea, e observei que os mexilhões possuíam água no seu interior, aparentemente estavam hidratados, mas não sei dizer se era muito ou pouco. $\mathrm{Na}$ espécie de caramujo de região entre marés, Nacella concinna, coletados na região da Antártida, em condições controladas de temperatura para a sua espécie $\left(0^{\circ} \mathrm{C}\right)$, a população coletada de região entre marés perdeu 5\% de água corpórea após 24 horas de exposição aérea, já a população do sub-litoral teve maior perda de água corpórea, em torno de 13\% (Weihe e Abele, 2008). Já Bayne et al., (1976), observou que a perda de água corpórea em mexilhões pode estar entre 20-30\% durante à exposição aérea, mas os tecidos não ficam ressecados, e segundo os autores, isto pode facilitar a troca de gases com a atmosfera, por expor uma larga área de superfície do fluido da cavidade do manto com o ar.

Do ponto de vista do metabolismo energético, em resposta à exposição aérea, os níveis de glicogênio nos mexilhões Mytilus californianus declinam no hepatopâncreas e músculo adutor, sem alteração para o tecido do manto (Bayne et al., 1976). Por outro lado, estes animais evocam rotas anaeróbias em resposta à exposição aérea ou à hipóxia, por exemplo, com aumento dos níveis de alanina e malato, servindo como substratos energéticos na anaerobiose (Bayne et al., 1976). Também ocorre a produção de metabólitos com função similar ao lactato, produto comum em vertebrados, mas de maneira geral, invertebrados marinhos possuem baixos níveis de LDH, e baixíssimos níveis de lactato quando em anaerobiose (Gonzalez e Quinones, 
2000; Hochachka e Somero, 2002). Estes metabólitos são produzidos a partir de aminoácidos livres em resposta à exposição aérea. Por exemplo, a alanina é convertida a alanopino na presença de piruvato e NADH por alanopino desidrogenase, tendo a mesma função de LDH, há outras enzimas como estrombino desidrogenase (que converte glicina em estrombino) e octopino desidrogenase (que converte arginina em octopino) (Sato et al., 1993).

Invertebrados marinhos ainda contam com arginina quinase, com função similar a creatina quinase de vertebrados, a enzima catalisa a reação entre argininafosfato na presença de ADP e produz ATP e arginina (ou vice-versa) (Ellington, 2001). Por exemplo, ao analisar a resposta enzimática de arginina quinase no músculo da calda da lagosta Orconectes virilis em resposta ao estresse da anóxia (20 horas), não houve alteração da atividade da enzima (comparando animais controle em normóxia versus animais em anóxia), esta teve menor grau de afinidade por arginina (maior Km) em relação aos animais controle (Dawson e Storey, 2012). Os autores sugerem que a sua atividade foi diminuída na direção da síntese de arginina-fosfato, favorecendo a reação em prol da formação de ATP (Dawson e Storey, 2012), mesmo sem terem medido se a enzima tem maior grau de afinidade por ADP ou argininafosfato. Por outro lado, sabe-se que os níveis de arginina-fosfato caem em resposta à anóxia em outras espécies, como forma de manter níveis adequados da produção de ATP (Gade, 1984). Além destas enzimas ajudarem na produção de ATP e na manutenção da homeostase redox (em relação aos níveis favoráveis da razão $\mathrm{NAD}^{+} / \mathrm{NADH}$ e manutenção do funcionamento da glicólise) durante a escassez de $\mathrm{O}_{2}$, outras rotas anaeróbias ascendem durante a exposição aérea, tendo como produto final a formação de succinato, nestes animais o succinato confere maior saldo de ATP quando comparado com os metabólitos citados brevemente (Harcet et al., 2013).

O succinato é produzido em resposta a uma hipóxia de curta duração, com a prolongação da hipóxia, este tende a ser metabolizado até a formação de propionato (Harcet et al., 2013). As enzimas relacionadas com a síntese destes metabólitos foram aumentadas nos tecidos de Geukenssia demissa, ao ser mediada exposição aérea e reimersão (Fields et al., 2014). Seis horas de exposição aérea em Mytilus californianus foram suficientes para o aumento de 21 vezes dos níveis de succinato, quando comparado com os animais reimersos (Connor e Gracey, 2012). Os moluscos 
não sabem que níveis aumentados de succinato na hipóxia causa aumento da produção de EROs pela mitocôndria (Chouchachi, 2014)? Curiosamente, neste trabalho, o succinato foi o metabólito que mais teve seus níveis aumentados no sistema de detecção por metabolômica, através de cromatografia líquida acoplada com espectrometria de massas (LC/MS), e não foi mencionado se xantina e hipoxantina foram detectados ou se sofreram alteração nos seus níveis de concentração (Connor e Gracey, 2012).

Há poucos trabalhos que estudaram a resposta antioxidante de animais na exposição aérea, com espécies de invertebrados, e todos feitos em laboratório, com raras exceções. Teixeira et al., (2013) submeteram a espécie de coral Veretillum cynomorium à exposição aérea, e em análise de corpo inteiro, observaram aumento de atividade de catalase (310\%) após duas horas de exposição aérea, em relação ao grupo de animais recém expostos ao ar (grupo zero). Houve também aumento dos níveis de atividade de GST, quando comparado com o grupo zero. As atividades das enzimas catalase e GST retornam ao nível do grupo zero após três horas de reimersão, e sem mudanças para os níveis de atividade de SOD nestas condições (Teixeira et al., 2013). Infelizmente, fica a dúvida se estes aumentos são reais, pois os parâmetros não foram padronizados por miligrama de proteínas, e os animais podem ter perdido água durante a exposição aérea. Medições por miligrama de proteínas evita este efeito de nível de hidratação de tecidos, comum entre vários trabalhos (Freire et al., 2011a; Welker et al., 2016). As enzimas podem estar mais concentradas por estarem em um meio com menor teor de água.

Em carangueijos, com Paralomis granulosa expostos ao ar por tempos entre três e 24 horas, o estudo de Romero et a.1, (2007) observou mudanças nas atividades de catalase, GST e SOD em diferentes tecidos (i.e. hemolinfa, brânquias, tecido muscular e hepatopâncreas). No tecido branquial, SOD cai após três horas de exposição aérea e se mantém baixa até o fim da exposição aérea, aumenta a atividade após seis horas no tecido muscular, voltando os níveis de atividade ao nível do controle após 12 e 24 horas de exposição aérea. No hepatopâncreas, a enzima tem aumento de atividade após três horas de exposição aérea, ficando com o mesmo nível de atividade entre seis e 12 horas, e retorna os níveis de atividade ao nível do controle após 24 horas de exposição aérea (Romero et al., 2007). Catalase e GST também 
aumentam de maneira geral nos outros tecidos em resposta à exposição aérea, com exceção de GST que teve seus níveis diminuídos no tecido muscular entre três e seis horas de exposição aérea, e após 12 horas de exposição aérea retorna no nível do controle (Romero et al., 2007). Este estudo ilustra bem como diferentes tecidos respondem diferentemente e temporalmente nos níveis de mudanças de atividade enzimática em resposta à exposição aérea, e as atividades das enzimas mais aumentam do que caem. Esta é uma resposta ao estresse oxidativo durante a exposição aérea? Ainda nos carangueijos, Freire et al., (2011a), compararam a resposta antioxidante frente à exposição aérea em duas espécies pertencentes ao mesmo gênero, Calinnectes danae e Callinectes ornatus. Em resposta a três horas de exposição aérea, não houve mudança nos níveis de atividade de catalase, Se-GPx (peroxidase específica para $\mathrm{H}_{2} \mathrm{O}_{2}$ ) e GST nas brânquias anteriores e posteriores em ambas as espécies (Freire et al., 2011a). Por outro lado, em C. ornatus, houve aumento dos níveis de atividade de catalase (280\%) e Se-GPx (140\%) no tecido muscular, GST não se alterou neste tecido, e em $C$. danae não houve alteração dos níveis de atividade para estas enzimas (Freire et a., 2011a). Por outro lado, no hepatopâncreas a atividade de catalase cai (90\%) em $C$. danae, porém sem alterações em C. ornatus (Freire et al., 2011a). Mesmo com a baixa da atividade de catalase, as enzimas mais aumentam do que caem, mais um caso de resposta ao estresse oxidativo na exposição aérea? Apesar de serem espécies próximas, mesmo gênero, elas têm respostas diferentes à exposição aérea. No caso, estas espécies possuem distribuições diferentes na região de estuário, $C$. ornatus prefere locais do estuário com maior teor de salinidade, e $C$. danae áreas com menor grau de salinidade, o que talvez explique as diferenças encontradas (Freire et al., 2011a).

Nos moluscos Chlamys farreri (bivalve), houve um leve aumento da atividade de SOD (39\%) em hemócitos após duas horas de exposição aérea (Chen et al., 2007). No mexilhão Perna perna, houve aumento dos níveis de GST (52\%) no hepatopâncreas em resposta a 18 horas de exposição aérea, sem alterações dos níveis de Eq-GSH e dos níveis de atividade de SOD, catalase e GPx, e sem ocorrência de mudanças destes parâmetros nas brânquias (Almeida et al., 2005). Estes mesmos sistemas foram avaliados em outro artigo (Almeida e Bayne, 2006), e SOD teve seus níveis de atividade aumentados (26\%) após 4 horas de exposição aérea. Assim como 
os resultados de Almeida et al., (2005), níveis de Eq-GSH, atividade de catalase e GPx não sofreram mudanças. Na ostra Pinctada fucata, houve queda dos níveis dos transcritos de GST e Prx nas brânquias após 1 hora de exposição aérea, e ausência de alterações dos transcritos para GPx (Kuchel et al., 2009). Este resultado significa que os RNAm foram traduzidos ou degradados? Ou a síntese destes foi diminuída, ao passo que a sua tradução ou degradação permaneceram com o mesmo ritmo? Ainda nos moluscos, Pöhlmann et al., (2011) mostraram que, nas brânquias de duas espécies de caramujos marinhos, a atividade de catalase não se alterou frente à exposição aérea (entre duas e 12 horas). Neste estudo, um dos bivalves, Nacella magellanica, foi coletado de duas regiões de regime entre marés, enquanto que a espécie Nacella deaurata fica sempre imersa, região de sublitoral. Não obstante, nas duas espécies $N$. Magellanica e $N$. deaurata, após 12 horas de exposição aérea, os níveis de atividade de SOD foram aumentados em 57 e 184\%, respectivamente. Porém, na mesma espécie $N$. magellanica, SOD aumentou somente em população de uma determinada região, e não em outra. Como explicar esta diferença dentro da mesma espécie? Apesar dos autores não explicarem tal resultado, uma sugestão da variabilidade encontrada, é que dadas as informações dos autores, os animais que foram coletados de um determinado local experimentam regimes de maré alta e baixa continuamente, entre duas e quatro horas de exposição aérea, por duas vezes ao dia, enquanto que os outros animais sofrem influencia das marés apenas na época de primavera (Pöhlmann et al., 2011). No artigo de Moreira et al., (2016), capítulo 2 desta dissertação, 57\% dos moluscos estudados respondem com aumento das defesas antioxidantes.

Alguns mexilhões possuem seu padrão de distribuição no substrato rochoso de maneira vertical, sendo que alguns indivíduos podem ficar mais perto d'água, com menor tempo de exposição aérea, enquanto os indivíduos distribuídos mais ao alto do rochedo podem passar mais tempo expostos ao ar, nomeadas áreas de baixo e alto rochedo (Tomanek e Somero, 1999). Ao comparar os níveis de atividade de SOD nas brânquias de Mytilus edulis em populações de alto e baixo rochedo, os animais do alto rochedo apresentavam maiores níveis constitutivos de atividade de SOD em relação aos animais do rochedo inferior (Letrende et al., 2008). Ambas as populações não tiveram alteração dos níveis de atividade em resposta à exposição aérea por seis horas e meia (Letrende et al., 2008). No hepatopâncreas, a atividade de SOD de ambas as 
populações caiu em resposta à uma hora e meia de exposição aérea, e voltou ao nível do controle após seis horas de exposição aérea, sem efeitos na atividade de SOD após 30 minutos de reimersão (Letrende et al., 2008). Os mexilhões do alto rochedo, com maiores níveis de SOD, estariam mais protegidos em relação ao estresse da hipóxia e reoxigenação, como resposta a maiores tempos de exposição aérea? Incrivelmente, em outro trabalho, do mesmo grupo, outros antioxidantes (GR, GST, GPx e catalase) em dois tecidos diferentes (brânquias e hepatopâncreas) também tiveram seus níveis de atividade superiores aos animais do baixo rochedo (Letrende et al., 2009). Na maioria dos trabalhos citados anteriormente, os antioxidantes tiveram seus níveis de atividade aumentados frente à exposição aérea, mas em todos os casos, a exposição aérea foi imposta.

A região entre marés é um local conveniente para avaliar o realismo fisiológico em seu contexto natural, em um 'laboratório' natural (Paine, 1966; Spicer, 2014). Neste ambiente, os mexilhões Mytilaster solisianus precisam responder fisiologicamente a estas flutuações diárias da retirada e oferta de $\mathrm{O}_{2}$, em meio a esperadas flutuações termais, e períodos de privação alimentar, e o esperado estresse oxidativo. Mesmo assim, não houve aumento nos níveis de GSH (figura 8) durante o ciclo das marés, com apenas uma queda dos níveis de Eq-GSH na coleta III (figura 7). Aparentemente, isto ocorreu não devido à exposição aérea, mas possivelmente pelo estresse da rápida mudança de temperatura do ar. Mas, ao mesmo tempo, não houve alteração da razão GSSG/Eq-GSH, visualmente é similar às coletas I e II (figura 10), o que indica ausência de maior desequilíbrio redox. Esses resultados inesperados levam algumas indagações. Teriam estes animais níveis já suficientes de GSH para responder à exposição aérea e a reimersão, ou estes animais estão controlando a produção de EROs gerados pela mitocôndria (considerado por alguns autores o principal sítio de EROs)? Ou ambos acontecem ao mesmo tempo? É importante citar que outros antioxidantes podem estar respondendo à exposição aérea, como SOD, GPx, GST, GR, Prx e tioredoxina, medidas estas necessárias para um contexto completo do sistema antioxidante. Outra pergunta que permanece em questão é: estes animais estão pré-condicionados a este ambiente? Isto implicaria em menor produção de EROs e menor nível de estresse oxidativo? Na coleta III, os animais estavam com os níveis de Eq-GSH relativamente maiores quando comparado com a coleta I e II. O 
que isto significa? Maior tempo de exposição aérea vivenciado em dias anteriores significa maiores níveis de GSH sintetizados previamente à exposição aérea de modo a responder e controlar o estresse oxidativo? Isto também acontece para outros antioxidantes? No trabalho de Fields et al., (2014), os autores mostraram que mexilhões de ambiente entre marés Geukensia demissa, após passarem por exposição aérea seguida de reimersão por 6, 12 e 18 horas, apresentavam níveis constitutivos aumentados de proteinas antioxidantes (p.ex. Prx, GST). Esta alta manutenção de proteínas antioxidantes na fase reimersa já seria uma resposta antecipatória para o estresse ambiental que estaria por vir novamente, o estresse da exposição aérea e reimersão (Fields et al., 2014).

Em dois artigos recentes sobre mudanças de antioxidantes em animais submetidos à privação de $\mathrm{O}_{2}$, com um alto grau de números de artigos citados, curiosamente não houve a descrição de estudos de animais que passam por estresses repetidos ou intermitentes, seja hipóxia ou anóxia (Hermes-Lima et al., 2015; Moreira et al., 2016). Possivelmente, a resposta de animais a um determinado estresse fisiológico (p,ex, hipóxia) difere dependendo de episódios anteriores de estresse. Por exemplo, há aqueles que passam por estresse e que se recuperam por um período qualquer de tempo, há aqueles que ao longo de sua vida nunca passaram por tal estresse, e há aqueles aclimatados por muito tempo em condições controladas. Isso leva a pergunta: eles terão necessariamente a mesma resposta para determinado marcador biológico, por exemplo, os antioxidantes (GSH)? A produção mitocondrial de EROs continua a mesma?

É bem sabido pelos cardiologistas que, ao submeter o miocárdio de mamíferos por períodos intermitentes e curtos de isquemia e reperfusão (entre 2-5 minutos), ocorre um aumento da resistência do tecido à morte celular e injúria por estresse oxidativo, com a ocorrência de menor geração de EROs pela mitocôndria (Halestrap et al., 2007). A explicação para esse fenômeno é que EROs produzidos em baixos níveis durantes períodos intermitentes e curtos de isquemia e reperfusão disparariam sistemas nas rotas de sinalização envolvendo a resposta adaptativa (como os antioxidantes), entre outros processos na defesa contra a injúria tecidual (Steeves et al., 1994; Gidday, 2006; Halestrap et al., 2007; Penna et al., 2009). Será que, fazendo uma analogia ao ambiente entre marés, com alterações cíclicas dos níveis de $\mathrm{O}_{2}$, isto 
pode conferir proteção aos animais produzindo menores níveis de EROs? Há um pré e pós-condicionamento evolucionário nesta espécie (entre outras) de zonas entre marés que possibilitam o seu alto grau de adaptabilidade a este ambiente hostil? Esta ideia em que a mediação de um estresse exógeno não letal e que configura proteção ou ganho de adaptabilidade frente à repetição do mesmo estresse se chama Hormesis, 'o que não mata fortalece' (Forbes, 2000; Gems e Partridge 2008; Constantine et al., 2010). Os autores consideram as enzimas antioxidantes e HSPs como efetores horméticos, no qual a mediação de um estresse estimula positivamente estes sistemas, que integradas ao nível de (epi) genoma, (epi) gene e proteínas, conferem a mediação da adaptabilidade animal frente ao mesmo estresse ou a outros tipos (Gidday, 2006). Além disto, esta adaptação adquirida pelos primeiros animais viventes de regiões entre marés (é apenas uma hipótese) possa ter sido passada pela genética e pela memória epigenetica para as gerações posteriores (Vaiserman, 2011; Galton, 2016).

Este tipo de procedimento experimental de análise de respostas bioquímicas ao longo do tempo, frente à descida e subida de marés também foi feita por outros autores no campo (Gracey et al., 2008), ou em condições que simulam o regime entre marés, de modo a controlar as variáveis ambientais do campo (Connor e Gracey, 2011). Nestes estudos, focando na análise global da expressão de genes, o transcritoma, indicativos de acoplamento de respostas ao estresse na emergência da exposição aérea acontecem na espécie Mytilus californianus. Eles mostraram que mudanças rítmicas e diferenciais de expressão gênica ocorrem em resposta à exposição aérea, e aumento dos níveis de expressão de genes que respondem a elevação termal, como as proteínas de choque térmico (HSP70 e 90), sendo que estes genes são mais expressos em populações de alto rochedo quando comparada com os animais de baixo rochedo (Gracey et al., 2008). Será que as HSPs estariam aumentadas em resposta à exposição aérea em Mytilaster solisianus? Sobre os antioxidantes, houve a deteç̧ão de transcritos para GST, Prx e GPx que foram aumentados em resposta à exposição aérea (Gracey et al., 2008). Interessantemente, nos mamíferos sensíveis à injúria da isquemia e reperfusão, no tecido renal, por exemplo, os níveis de RNAm para SOD, catalase e GPx caem, bem como os seus níveis de atividade e proteicos (Dobashi et al., 2000). 
Interessantemente, Zhang et al., (2012), ao estudarem o genoma (sequenciamento) e transcritoma da ostra Crassostrea gigas que vive em regiões entre marés, mediaram exposição aérea por vários dias (entre 1 a 10 dias), observaram que esta espécie possui diferentes cópias de genes para HSP70, GST, BAX (do inglês BCL2-associated X protein) e BCL2 (do inglês B cell linfoma 2), com um número superior de cópias destes genes ao encontrado em outras espécies, e seus transcritos aumentam em resposta à exposição aérea, incluindo Prx. Ao mediar estresse termal nesta espécie, houve aumento dos transcritos de HSP70 em torno de 2000 vezes (Zhang et al., 2014). Os autores explicam que a grande corrente de genes com funções anti-apoptose (BLC2, BAX e GST), em conjunto com altos níveis de expressão de HSPS, configuram a adaptabilidade destes animais a este ambiente, que podem experimentar no verão temperaturas em torno de $49^{\circ} \mathrm{C}$ (Zhang et al., 2012). Logo, esta espécie teria todo um arsenal bioquímico que confere adaptabilidade a este ambiente. Isto também acontece em Mytilaster solisianus? Caso sim, isto explicaria em parte a forte tolerância destes animais ao insulto do estresse termal observado na coleta III?

Infelizmente há limitações diversas neste tipo de estudo, como o não controle da temperatura ambiental, a falta de dados da qualidade da água do mar, $\mathrm{pH}$, salinidade e os níveis de $\mathrm{O}_{2}$ dissolvido. Foram levados para a praia instrumentos de medição de $\mathrm{O}_{2}$, salinidade, e $\mathrm{pH}$, porém não funcionaram. Estes dados seriam importantes para um completo panorama ambiental que pode ou não influenciar a resposta fisiológica dos mexilhões ao ciclo das marés. 
ANEXO A - Foto da pedra na qual os animais (pontos pretos) foram coletados. Foto específica da coleta I.

Autor das fotos: Marcus Sabino.
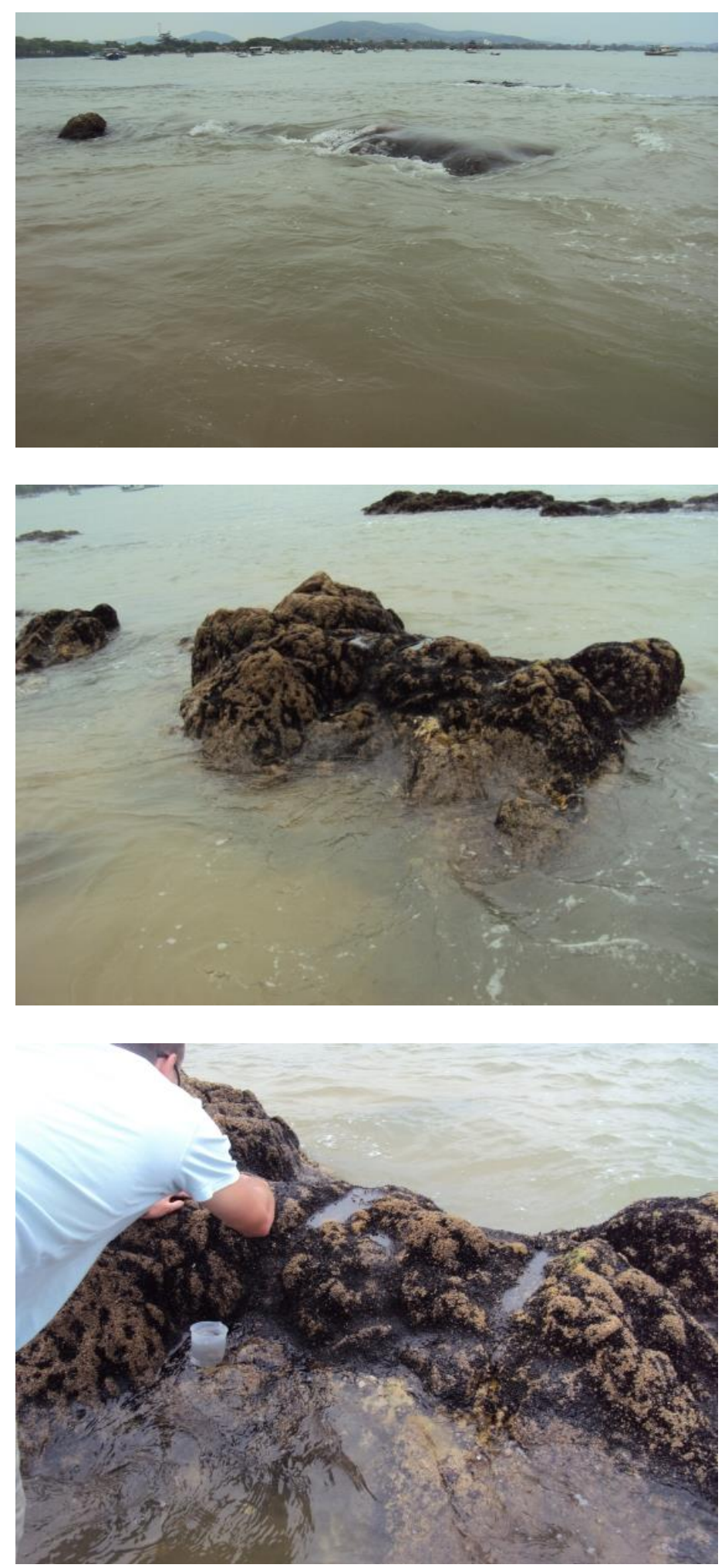
ANEXO B - Registro por fotos ao longo do tempo durante a baixa e alta da maré na coleta III. Ao centro, registro da temperatura do ar e água em função do tempo. No painel superior da figura, condição de coleta dos animais, incluindo tempo no qual os mesmos estavam reimersos (círculos em preto) ou expostos ao ar (os círculos em branco). Autor das fotos e figura: Marcus Sabino.

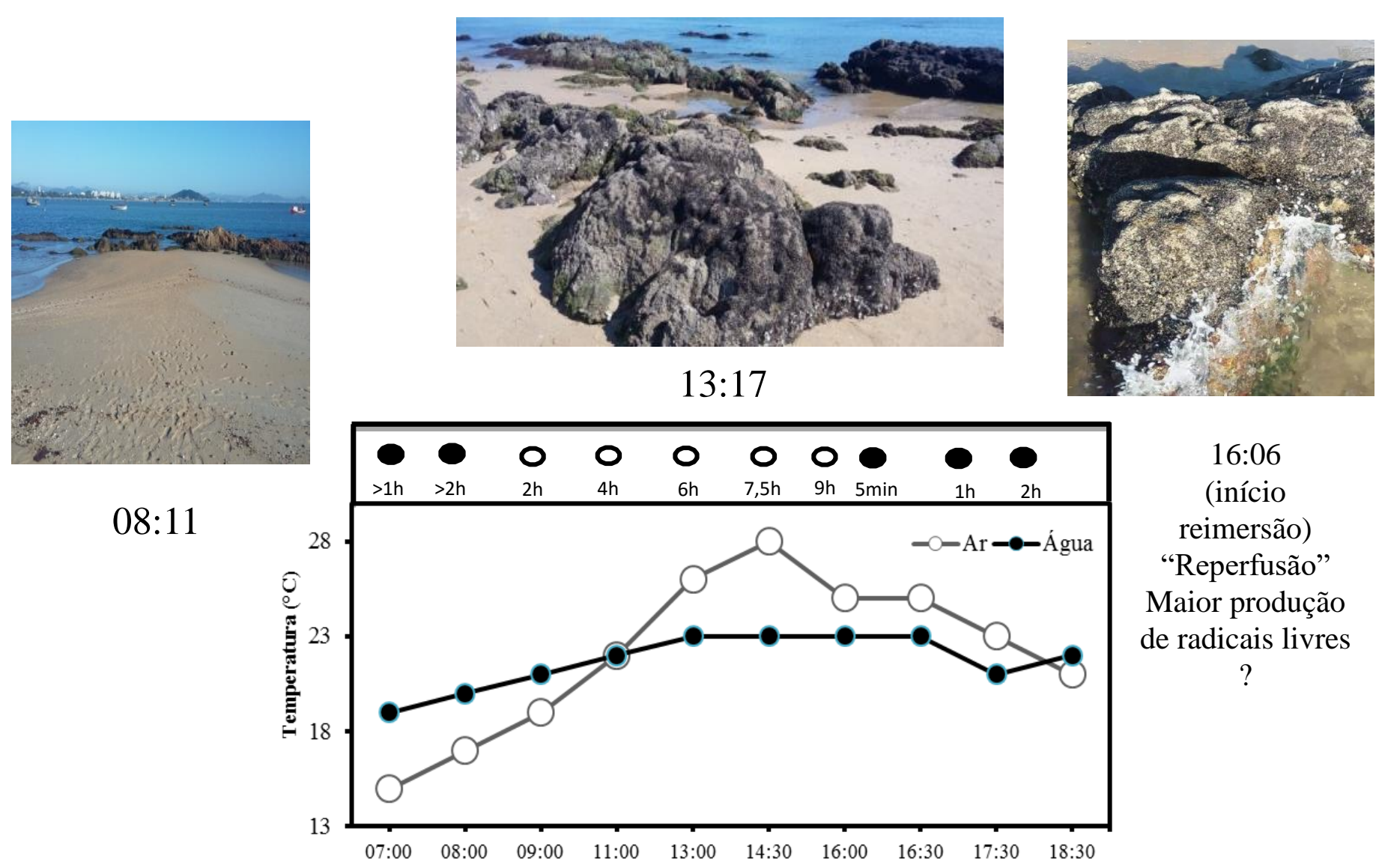

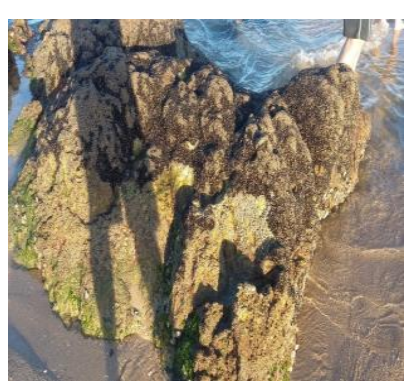

07:26

Início da exposição aérea "isquemia". Maior produção de radicais livres?

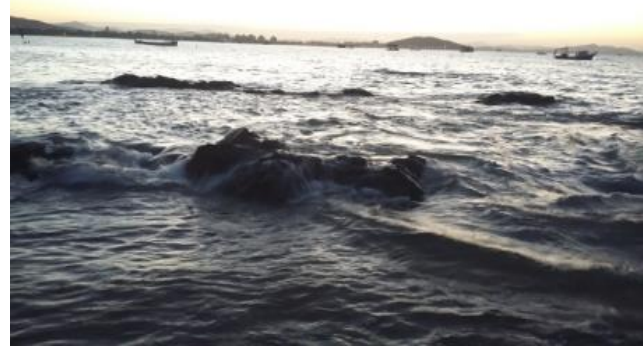

18:55

Completa reimersão 